\title{
OXYGEN ISOTOPE RATIOS IN \\ COEXISTING MINERALS OF REGIONAIJY \\ METAMORPHOSED ROCKS
}

Thesis by

George Donald Garlick

In Partial Fulfillment of the Requirements

For the Degree of

Doctor of Philosophy

Califormia Institute of Technology

Pasadena, California

1965

(Submitted June 2, 1964) 
PLEASE NOTE:

Figure pages are not original copy. They tend to "curl". Filmed in the best possible way.

University Microfilms, Inc. 


\section{ACKNOWLEDGEMENTS}

I wish to thank Dr. Samuel Epstein for guiding and encouraging me throughout the course of this research.

Drs. A. L. Albee, A. Hietanen, J. L. Rosenfeld, H. P. Taylor, and Mr. R. Naylor generously contributed specimens for analysis. I am also grateful for the rewarding discussions I have had with Drs. A. I. Albee, W. B. Kamb, J. R. O'Neil, L. T. Silver, H. P. Taylor, and G. J. Wasserburg.

Assistance with the construction and maintenance of the apparatus was received from Mr. C. Bauman and Mr. E. V. Nenow.

Financial assistance was provided by a Kennecott Copper Corporation Fellowship, a Harvey Mudd Summer Fellowship, and a grant from the Penrose Bequest. Funds for the construction and maintenance of the apparatus were obtained from the Atomic Energy Commission. 
ABSTRACT

The $0^{18} / 0^{16}$ ratios of coexisting minerals from a number of regionally metamorphosed rocks have been measured, using a bromine pentafluoride extraction-technique. Listed in order of their increasing tendency to concentrate $0^{18}$, the minerals analyzed are magnetite, 11 menite, chlorite, biotite, garmet, hornblende, kyanite, muscovite, feldspar, and quartz. The only anomalous sequence detected occurs in a xenolith of schist, in which quartz, muscovite, biotite, and ilmenite, but not garnet, have undergone isotopic exchange with surrounding trondjemite.

With few exceptions, quartz-magnetite and quartz-ilmenite fractionations decrease with increasing metamorphic grade determined by mineral paragenesis and spatial distribution. This consistency does not apply to quartz-magnetite and quartz-ilmenite fractionations obtained from rocks in which petrographic evidence of retrogradation is present.

Whereas measured isotopic fractionations among quartz, garnet, ilmenite, and magnetite are approximately related to metamorphic grade, fractionations between these minerals and biotite or muscovite show poor correlation with grade. Variations in muscovite-biotite fractionations are relatively small. These observations are interpreted to mean that muscovite and biotite are affected by retrograde re-equilibration to a greater extent than the anhydrous minerals analyzed.

Measured quartz-ilmenite fractionations range from 12 permil in the biotite zone of central Vermont to 6.5 permil in the sillimanite- 
orthoclase zone of southeasterm Connecticut. Analyses of natural assemblages from the kyanite and sillimanite zones suggest that equilibrium quartz-ilmenite fractionations are approximately 8 percent smaller than corresponding quartz-magnetite fractionations. Employing the quartz-magnetite geothermometer calibrated by $0^{\prime} \mathrm{Ne} i l$ and Clayton (1964), a temperature of $560^{\circ} \mathrm{C}$ was obtained for kyanite-bearing schists from Addison County, Vermont. Extending the calibration to quartz-ilmenite fractionations, a temperature of $600^{\circ} \mathrm{C}$ was obtained for kyanite-schists from Shoshone County, Idaho. At these temperatures kyanite is stable only at pressures exceeding 11 kbars (Bell, 1963), corresponding to lithostatic loads of over $40 \mathrm{~km}$. 
TABLE OF CONLENTS

Page

ACKNOWLEDGEMENTS . . . . . . . . . . . . . . . . . 11

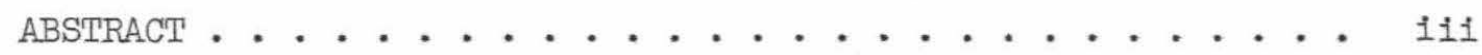

Part Section $\quad$ Title

I

INTRODUCTION ...................... 1

1.1 General statement ........... 1

1.2 Historical background......... 2

1.3 Previous metamorphic studies ....... 4

1.4 Geothermometry ........... 7

II THEORETICAL CONSTDERATIONS . . . . . . . 8

2.1 Notation and terminology ....... 8

2.2 Equilibrium Practionation of isotopes.... 10

2.3 Temperature dependence ........ 12

2.4 Pressure dependence......... 13

2.5 Isotopic behavior of ionic solutions .... 15

2.6 Isotopic diffusion .......... 16

III ARALYTICAL TECHNIQUE . . . . . . . . . 19

3.1 Mass spectrometry ........... 19

3.2 Correction factors .......... 22

3.3 Analytical precision ........ 26

3.4 Isotopic standards .......... 26

3.5 Sample preparation ......... 28

3.6 Sample-contamination corrections ..... 31

3.7 oxygen extraction........... 32

3.8 Analytical precautions ........ 38

3.9 Relative merits of $\mathrm{BrF}_{5}$ and $\mathrm{F}_{2} \ldots . . . .47$

IV PETROLOGICAL CONSIDERATIONS . . . . . . . 49

4.1 Grades of metamorphism ......... 49

4.2 Equilibrium mineral assemblages ...... 50

Preservation of high-temperature
assemblages .................. 51

$\mathrm{V}$ GEOLOGY AND ISOTOPIC RESULTS OF

INDIVIDUAL AREAS . . . . . . . . 53

5.1 Dutchess County, southeasterm New York . . 53

5.2 Addison County, central Vermont ...... 66 
Part Section Pitle Page

5.3 Southern Vermont ........ 74

5.4 Central Connecticut ......... 83

5.5 Northerm Idaho ........... 88

VI GENERAL DISCUSSION OF RESULTS . . . . . . . 96

6.1 Relative $0^{18} / 0^{16}$ ratios in coexisting minerals . . . . . . . . 96

6.2 Isotopic fractionations related

6.3 Problems of non-equilibrium . . . . . . 107

6.4 Regional homogenization of isotopic

6.5 Amphibolites . . . . . . . . . . . . . . 126

VII GEOTHERMOMETRY . . . . . . . . 128

7.1 Introduction .......... 128

7.2 Temperature dependence of quartz-

7.3 Temperature dependence of quartz-

7.4 Retention of isotopic records....... 133

7.5 Indicated temperatures of metamorphism . . 135

7.6 Variations in $\beta$-parameter . . . . . . . 150

7.7 Isotopic effects of retrogradation .... 154

7.8 Pressures during metamorphism . . . . . . 164

7.9 Geothermal gradients during metamorphism . . 167

7.10 Comparison of isotopic with other estimates
of temperature ................. 171

VIII SUMMARY AND CONCLUSIONS . . . . . . . 180

IX BIBLIOGRAPHY ...................... 183

X IIDEX TO APPENDICES 1 AND $2 \ldots \ldots$. . . . . . 190 
CHAPTER I

\section{INTRODUCTION}

\subsection{General statement}

The relative abundances of the three stable isotopes of oxygen in ocean water are:

$$
\begin{aligned}
& 0^{16}: 0.9976 \\
& 0^{17}: 0.0004 \\
& 0^{18}: 0.00199
\end{aligned}
$$

The $0^{18} / 0^{16}$ ratio in natural minerals has a range of variation equal to about 3 percent, which can be measured mass-spectrometrically with a precision of \pm 0.01 percent.

Variations in the isotopic composition of rocks and minerals provide valuable information on their genesis. In particular, when isotopic equilibrium between two coexisting minerals is established at a certain temperature, and preserved to the present time, that temperature can be determined by comparing the isotopic fractionation with equilibrium fractionations obtained by experiment. The consistency of temperatures determined from the partition of isotopes among various mineral pairs in an assemblage is an indication that equilibrium was achieved. Conversely, non-equilibrium is demonstrated when the criterion of internal consistency fails, or when the indicated temperature is unacceptable on the basis of known conditions in the earth's crust. 
The absence of isotopic equilibrium among the minerals of an assemblage and among the rocks of a metamorphic province may also be of value by reflecting the diverse histories of the various minerals and rocks. Disequilibrium among metamorphic rocks can often be interpreted in terms of isotopic variations in the precursor rocks. Disequilibrium in mineral assemblages may be more difficult to decipher.

The objectives of this research are:

1. To determine the applicability of oxygen-isotope techniques in elucidating the petrogenetic processes of regional metamorphism;

2. To investigate the attainment and retention of isotopic equilibrium between minerals and rocks in metamorphosed terrains;

3. To ascertain the temperatures of formation of metamorphic rocks by means of the quartz-magnetite geothermometer calibrated by $0^{\prime} \mathrm{Neil}$ and Clayton (60).

\subsection{Historical background}

The significance of isotopic fractionations in equilibrium systems was appreciated by Urey and Greiff (84) as early as 1935 . The Nier mass spectrometer (59), later modified by McKinney et al. (56), permitted geochemists to study the isotopic composition of oxygen in nature with great analytical precision. 
Analytical procedures employed in the extraction of oxygen from silicates fall into two principal categories:

1. The reduction by carbon at high temperatures to yield carbon monoxide;

2. The oxidation by fluorine or halogen fluorides to yield oxygen.

The liberated gas is usually converted to carbon dioxide for mass spectrometric analysis.

The carbon reduction method has been used by Baertshi and Schwander (2), Schander (68), Vinogradov et al. (86), and Dontsova (23). Clayton and Epstein (14) have demonstrated that minerals containing alkali metals, alkaline earths, or aluminum cannot be conveniently analysed in this manner with any great precision, due to the re-oxidation of volatilized elements in the cooler parts of the apparatus.

The use of fluorine and halogen fluorides at $420^{\circ} \mathrm{C}$ for the liberation of oxygen from silicates was attempted by Baertschi and Silverman (71). Fluorine was found to be more effective than chlorine trifluoride because oxygen yields from the latter reagent were incomplete. Taylor and Epstein (74) have successfully used fluorine at $500^{\circ} \mathrm{C}$ for the liberation of oxygen from many silicate minerals. Bromine trifluoride has been used to liberate oxygen from uranium oxides by Hoekstra and Katz (41), from phosphates by Tudge (81), and from silicates by Clayton and Mayeda (16), but the vapor pressure of bromine trifluoride is inconveniently low. Clayton and Mayeda (16) 
also used bromine pentafluoride for the extraction of oxygen from various minerals, and claimed quantitative yields from minerals, such as olivine, which had been found to be rather refractory in the presence of fluorine.

\subsection{Previous metamorphic studies}

The isotopic behavior of oxygen in metamorphic rocks has been investigated by Silverman (71), Schwander (68), Engel, Clayton and Epstein (26), Taylor and Epstein (75), James and Clayton (44), and by Taylor, Albee and Epstein (76).

Silverman (71) measured the whole-rock oxygen-isotopic composition of 6 schists from an area of progressive metamorphism in Dutchess County, New York. As expected, the $0^{18} / 0^{16}$ ratios were found to lie between those characteristic of igneous rocks and marine authigenic minerals.

Schwander (68) determined the relative whole-rock compositions of a wide variety of metamorphic rocks. The contact metamorphism of slates adjacent to the Barr-Andlau granite (Vosges, France) and the Huelgoat granite (Brittany, France) resulted in a progressive depression of $0^{18} / 0^{16}$ ratios as the granites were approached.

The isotopic composition of oxygen in the Leadville limestone (Colorado) and in the hydrothermal dolomites and contact metamorphic marbles that replaced the limestone was studied by clayton and Epstein (14) and Engel et al. (26). Isotopic fractionations be- 
tween quartz and calcite within the halo of hydrothermal dolomite in the Gilman area decrease fairly systematically as ore and obvious conduits are approached.

Taylor and Epstein (75) studied the progressive metamorphism in the Winchester-Hemet area just east of the Southern California batholith. K-feldspar and biotite were isotopically analysed in 4 specimens. The specimens ranged from biotite grade to sillimanite grade, and were collected from a uniform stratigraphic unit that was originally an arkosic sandstone. It was noted that the $0^{18} / 0^{16}$ ratios in these minerals were about 5 permil higher than the ratios in corresponding minerals from igneous rocks. The isotopic differences between the coexisting pairs were approximately equal to the corresponding differences in igneous rocks. Taylor and Epstein also analysed coexisting plagioclase and hormblende in 3 amphibolites from the Adirondack Mountains, New York, and 2 amphibolites from the Black Hills, South Dakota. The $0^{18} / 0^{16}$ ratios were a few permil higher than those found in igneous rocks, and the differences were 0 to 4 permil greater than those found in igneous rocks. It was concluded that, although the degree of equilibrium attained during metamorphism varied from rock to rock and even from mineral to mineral, the observed isotopic fractionations were generally compatible with the theoretically expected trend of larger isotopic fractionations at lower temperatures. Taylor and Epstein noted that the metamorphic rocks tend to approach the igneous rock range of oxygen isotopic compositions at the highest temperatures of metamorphism, 
and suggested that this was due to oxygen exchange with an oxygen reservoir having an isotopic composition similar to that of igneous rocks.

James and Clayton (44) have analysed the isotopic compositions of magnetite, hematite, quartz, and calcite from the regionally metamorphosed iron formations of Michigan, Wisconsin, and Minnesota. Approximate relationships between metamorphic grade and isotopic fractionations were obtained. Inconsistencies in rocks of higher metamorphic grade than the garmet grade were attributed to retrogradation. The data are discussed, with reference to processes of retrogradation, in section $7 \cdot 7$.

Another study of significance to this thesis is that of the kyanite-zone pelitic schists from the Lincoln Mountain quadrangle, Vermont, undertaken by Taylor, Albee, and Epstein (76). Several coexisting minerals in 3 chemically different pelitic schists were isotopically analysed, using a fluorine-extraction technique. The 3 rocks, representing 3 equilibrium mineral-assemblages, were collected within 200 meters of one another in a metamorphic terrain uncomplicated by intrusives or retrogradation. The presence of primary chlorite in such high-grade rocks indicates that a high activity of water prevailed during the metamorphism in this area. The results of this investigation are included in figure 9. The main conclusions are:

1. Isotopic equilibrium among the coexisting minerals was established during metamorphism, and was attained at the same temperature for all 3 rocks. 
2. The 3 rocks were also equilibrated with a common oxygenbearing fluid and were thus in isotopic equilibrium with one another.

\subsection{Geothermometry}

The equilibrium isotopic fractionation of oxygen between coexisting minerals is a function of temperature. The pressuredependence of the fractionation factor is assumed to be negligible. If the fractionation factor is known as a function of temperature, and if the equilibrium fractionation can be measured, the temperature of equilibration can be determined. The principles of isotopic thermometry have been applied by Epstein et al. (27) to low temperature carbonate-water systems and by Clayton et al. (15) to high temperature quartz-carbonate-iron oxide systems.

The quartz-magnetitite geothermometer, recently calibrated in the laboratory by $0^{\prime} \mathrm{Ne} i \mathrm{l}$ and Clayton (60), is used in this thesis. Adequate laboratory investigations have not been conducted on any other minerals commonly found in pelitic schists. 


\section{CHAPTER II}

\section{THEORETICAL CONSIDERATIONS}

\subsection{Notation and terminology}

This work is primarily concerned with the ratio of $0^{18}$ to $0^{16}$ in one mineral relative to that in another. The fractionation factor $\left(\alpha_{B}^{A}\right)$ for two minerals $A$ and $B$ is defined by

$$
\alpha_{B}^{A}=\frac{0^{18} / 0^{16}(\mathrm{~A})}{0^{18} / 0^{16}(\mathrm{~B})} \text {, }
$$

where $0^{18} / 0^{16}$ (A) is the measured ratio in mineral $\mathrm{A}$.

All analyses are reported in terms of the quantity $\delta$ :

$$
\delta_{\mathrm{A}}=1000\left(\frac{0^{18} / 0^{16}(\mathrm{~A})}{0^{18} / 0^{16}(\text { Standard })}-1\right) .
$$

The reference standard is Standard Mean Ocean Water (SMOW), which is defined in section 3.4 .

Thus,

$$
\delta_{\mathrm{A}}=1000\left[\alpha_{\mathrm{SMOW}}^{\mathrm{A}}-1\right]
$$

and

$$
\begin{aligned}
& \frac{1}{1000}\left[\delta_{A}-\delta_{B}\right]=\alpha_{\text {SMOW }}^{A}-\alpha_{\text {SMOW }}^{B} \\
&=\alpha_{\text {SMOW }}^{B}\left[\alpha_{B}^{A}-1\right] . \\
& \therefore \frac{1}{1000}\left[\delta_{A}-\delta_{B}\right] \approx \alpha_{B}^{A}-1 .
\end{aligned}
$$


The quantity $\left(\delta_{A}-\delta_{B}\right)$ is reported as the permil fractionation between minerals $A$ and $B$, and is sometimes replaced by the symbol $\Delta_{B}^{A}$. The terms fractionation and fractionation factor should not be confused.

The logarithm of a fractionation factor is related to the fractionation by the following equations:

$$
\begin{aligned}
\ln \alpha_{B}^{A}= & \ln \alpha_{\text {SMOW }}^{A}-\ln \alpha_{\text {SMOW }}^{B} \\
& \approx \frac{\delta_{A}-\delta_{B}}{1000} .
\end{aligned}
$$

More accurately,

$$
\ln \alpha_{B}^{A}=\gamma\left(\alpha_{B}^{A}-1\right),
$$

and

$$
1000 \text { In } \alpha_{B}^{A}=\frac{\gamma}{\alpha_{\text {SMOW }}^{B}} \Delta_{B}^{A} \text {. }
$$

where the correction factor $\gamma$ varies from 1 to 0.995 as $\alpha$ varies from 1 to 1.012. In the present work, the value of $\gamma / \alpha_{\text {SMOW }}^{B}$ for quartz-ilmenite fractionations ranges from 0.996 to $0.990 . \quad \gamma / \alpha_{\text {SMOW }}^{B}$ was assumed to be 0.993 in all cases involving fractionations between quartz and ilmenite or magnetite.

The $\delta_{A}$ and $\triangle_{B}^{A}$ notations are chiefly used in the descriptive parts of this thesis. The term 1000 In $\alpha_{B}^{A}$ is mathematically less cumbersome than $\Delta_{B}^{A}$, and is therefore employed when quantitative data are processed.

In order to facilitate discussion of the relative tendencies of minerals to concentrate $\mathrm{O}^{18}$, the isotopic compositions of minerals 
are normalized by means of the $\beta$-parameter:

$$
\begin{aligned}
\beta(A) & =\frac{\ln \alpha_{M}^{A}}{\ln \alpha_{M}^{Q}} \\
& \approx \frac{\delta_{A}-\delta_{M}}{\delta_{Q}-\delta_{M}}
\end{aligned}
$$

where $\beta(A)$ denotes the " $\beta$-parameter" of mineral $A, Q$ denotes quartz, and $M$ denotes magnetite. $A, Q$ and $M$ occur in the same mineral assemblage. The $\beta$-parameter is a measured quantity.

\subsection{Equilibrium fractionation of isotopes}

Consider the exchange reaction:

$$
\mathrm{aAO}_{\mathrm{n}}+\mathrm{bBO}_{\mathrm{m}}^{*}=\mathrm{aAO} \mathrm{n}_{\mathrm{n}}^{*}+\mathrm{bBO}_{\mathrm{m}}
$$

with an $=\mathrm{bm}$. The superscript $*$ denotes the presence of the heavier isotope to the exclusion of the other. The absence of the superscript denotes the exclusive presence of the lighter isotope.

Assuming a random distribution of isotopes within each species, it can be shown that the equilibrium constant and equilibrium fractionation factor are related by:

$$
\alpha^{\text {na }}=K
$$

In many natural crystals there exist more than one type of oxygen site. For example, the micas contain hydroxyl groups in addition to the oxygen atoms bound to silicon and aluminum. In such cases, a single crystalline phase may be treated as two or more isotopic sub-phases. 
Successful calculations of isotopic equilibrium constants have been performed for gases. In the case of perfect gases,

$$
K=\frac{\left(Q_{A O^{*}} / Q_{A O}\right)^{a}}{\left(Q_{B O^{*}} / Q_{B O}\right)^{b}},
$$

where $\mathrm{Q}_{\mathrm{AO}}$ is the molecular partition function of the species $A 0^{*}$. An approximate expression relating the partition functions to the frequencies of vibration of nonlinear, polyatomic molecules is given by Urey (83):

$$
\frac{S^{*}}{S}\left(\frac{m}{m^{*}}\right)^{3 n / 2} \frac{Q^{*}}{Q}=\pi \frac{u_{i}^{*}}{u_{i}} \cdot \frac{e^{-u_{i}^{*} / 2}}{e^{-u_{i} / 2}} \cdot \frac{1-e^{-u_{i}}}{1-e^{-u_{i}^{*}}},
$$

where $S^{*}=$ the symmetry number of the heavier molecule

$\mathrm{m}^{*}=$ the mass of the heavier isotope

$\mathrm{n}$ = the number of isotopic atoms exchanged per molecule

$u_{i}=h v_{i} / k T$

$v_{i}=$ the frequency of vibration of mode $i$

$\mathrm{h}=$ Planck's constant

$\mathrm{k}=$ Boltzmann's constant

$T$ = the absolute temperature.

The ratios of isotopic masses will cancel in any isotope exchange reaction, and the ratio of the symmetry numbers cannot result in any isotopic enrichment, as it represents only the relative probabilities of forming symmetrical and unsymmetrical molecules. If only one exchangeable atom occurs in each molecule, or if the two 
molecules are fully exchanged, the ratio of symmetry numbers is unity.

Equation 16 permits the calculation of partition function ratios from a knowledge of vibrational frequencies alone.

This research is primarily concermed with crystalline phases for which much of the above treatment is inadequate. Similar principles are involved, however, and the theoretical treatment is useful in predicting the qualitative behavior of isotopes in condensed phases.

\subsection{Temperature dependence}

At extremely high temperatures, such that $\mathrm{kT} \gg \mathrm{h} v$, the vibrational partition functions approach their classical values $\mathrm{kT} / \mathrm{h} v$, and there is no fractionation of isotopes. At very low temperatures, isotopic effects are most pronounced.

The Bigeleisen and Mayer (7) approximation of equation 16 is helpful in predicting the temperature dependence of exchange equilibria:

$$
\ln \frac{Q^{*}}{Q}\left(\frac{m}{m^{*}}\right)^{3 n / 2}=\ln \frac{s}{s^{*}}+\sum_{i} g\left(u_{i}\right) \Delta u_{i},
$$

where

$$
g\left(u_{1}\right)=\frac{1}{2}-\frac{1}{u_{1}^{*}}+\frac{1}{e^{u_{1}^{*}}-1}
$$

and

$$
\Delta u_{i}=u_{1}-u_{i}^{*}
$$

$$
\text { (s/s* for exchange reaction } 13 \text { is unity.) }
$$


When $u_{1}<3, g\left(u_{1}\right) \approx u_{1} / 12$, and $\ln K \approx$ constant $/ T^{2}$. When $8<u_{1}<25, g\left(u_{1}\right) \approx 0.4$, and In $K \approx$ constant/T.

The frequencies of vibration of oxygen bonds in silicates are of the order of $3 \times 10^{13} \sec ^{-1}\left(\therefore v / c=\omega=1000 \mathrm{~cm}^{-1}\right)$. Thus, at temperatures greater than $300^{\circ} \mathrm{K}, u_{1}<2$. Fractionations between silicates are therefore predicted to exhibit the following behavior:

$$
\text { In } \alpha \approx \frac{1}{\mathrm{na}} \text { In } \mathrm{K} \approx \text { constant } / \mathrm{T}^{2} .
$$

It should be remembered that the foregoing considerations involve many assumptions, and are a poor substitute for experimental observations.

\subsection{Pressure dependence}

The difference between the pressures at which the metamorphic rocks of this study crystallized and the pressure of one kilobar used by $O^{\prime} N e i l$ and Clayton (60) in the laboratory determinations of quartzmagnetite fractionations may be as great as $10 \mathrm{kbars}$. This difference in pressure may have a significant effect on the isotopically determined temperatures of metamorphism, but pertinent experimental information is not available.

The exchange reaction of interest is:

$$
2 \mathrm{SiO}_{2}^{16}+\mathrm{Fe}_{3} \mathrm{O}_{4}^{18} \leftrightharpoons 2 \mathrm{SiO}_{2}^{18}+\mathrm{Fe}_{3} \mathrm{O}_{4}^{16}
$$

In the temperature range of $500^{\circ}$ to $600^{\circ} \mathrm{C}$,

$$
\left(\frac{\partial \ln \alpha}{\partial T}\right)_{p} \approx 1.6 \times 10^{-5} \quad \text { (See figure 23) }
$$


The relationship between $\alpha$ and pressure is given by:

$$
4\left(\frac{\partial \ln \alpha}{\partial p}\right)_{T}=\left(\frac{\partial \ln K}{\partial p}\right)_{T}=\frac{\Delta V}{R T} .
$$

Hence, if the effect of pressure on the quartz-magnetite geothermometer is not to exceed 10 degrees per kilobar, the fractional volume change $\left(\frac{\Delta V}{V}\right)$ resulting from complete isotopic exchange must not exceed $5 \times 10^{-4}$.

The volumetric effect of isotopic substitution has been estimated by Joy and Libby (46). They related the effective volume of a molecule with the maximum bond lengths achieved in the course of normal stretching vibrations of the molecule in the lowest energy state. The fractional volume change on substitution of $0^{18}$ for $0^{16}$ in the carbonate ion or calcite was estimated to be approximately $10^{-3}$. However, the contribution of the amplitudes of vibrations to the effective volume of a molecule is not known, and the average bond length of an isolated oscillation is, to a good approximation, independent of isotopic substitution. Hence, the treatment of Joy and Libby probably yields a maximum estimate of the volumetric effect of isotopic substitution.

Because volumetric effects will tend to cancel in an exchange reaction, the fractional volume change accompanying the exchange of isotopes between two phases is expected to be much smaller than the fractional volume change in a single phase. The considerations of Joy and Libby therefore suggest that the pressure dependence of the quartz-magnetite thermometer will not exceed 10 degrees per kilobar. 
One indication that pressure is not an important variable in determining the isotopic composition of substances is found in the experimental work of Hoering (42). The average of 3 determinations of the isotopic fractionation of oxygen between bicarbonate ion and water at 4 kbars differed from the atmospheric-pressure determinations by $0.2 \pm 0.2$ permil. Joy and Libby predicted an effect one order of magnitude larger than this average.

In the absence of experimental observations of the effect of pressure on the partition of oxygen isotopes between minerals, it will be assumed that the pressure-dependence is negligible within the pressure range in which the metamorphic rocks of this study were formed. It will also be assumed that the quartz-magnetite geothermometer requires no pressure correction.

\subsection{Isotopic behaviour of ionic solutions}

The investigations of Taube (72) on the effects of dissolved salts on the isotopic exchange between water and carbon dioxide indicate that the water of hydration surrounding cations with relatively large charge/radius ratios (e.g. $\mathrm{Mg}^{++}$and $\mathrm{Al}^{+++}$) is usually enriched in $0^{18}$. Sodium ions appear to have no isotopic effect on the surrounding water. The effects appear to be insensitive to the type of anion present.

Equilibrium fractionations between quartz and 0.8 molar sodium fluoride solutions were used in the calibration of the quartzmagnetite thermometer. Taube's data suggest that the presence of 
$\mathrm{NaF}$ did not influence the $\mathrm{SiO}_{2}-\mathrm{H}_{2} \mathrm{O}$ fractionation to any appreciable extent.

In metamorphic rocks, we are more concerned with the behavior of pore fluids as media of exchange than with their actual isotopic compositions. Therefore, the dependence of the isotopic behavior of water on dissolved materials is of minor consequence to this study.

\subsection{Isotopic diffusion}

The application of isotopic fractionations in determining the temperatures of crystallization of rocks is dependent upon the preservation of the isotopic compositions obtained during crystallization.

If the surface isotopic composition of a previously homogeneous solid is changed and maintained at a new value, diffusion within the solid will take place and tend to erase the disequilibrium established between the surface and interior. If the solid is an isotropic cube and the process is arrested before equilibrium is attained, the bulk change in isotopic composition, as given by Jost (45), is:

$$
\frac{C_{\infty}-C_{t}}{C_{\infty}-C_{0}}=\frac{512}{\pi^{6}}\left[\sum_{n=0}^{\infty} \frac{1}{(2 n+1)^{2}} \exp \left(\frac{-D \pi^{2} t}{a^{2}}(2 n+1)^{2}\right)\right]^{3},
$$

where $t=$ time

$$
\begin{aligned}
& \mathrm{C}_{\mathrm{x}}=\text { mean concentration of an isotope at } \mathrm{t}=\mathrm{x} \\
& \mathrm{d}=\text { length of the edge of the cube. }
\end{aligned}
$$


This equation is fairly realistic in that equilibrium between the surfaces of mineral grains could be established very rapidly compared with the rates of diffusion through the crystal lattices.

Hutchinson (43) has reported that exchange between oxygen and silica at $750^{\circ} \mathrm{C}$ to $1000^{\circ} \mathrm{C}$ is negligible unless water is present. Whether the water promotes recrystallization of the silica, permits more rapid duffusion within the quartz, or catalyzes the exchange reaction is not clear.

Wyart (88) has reported the results of a few experiments on the rates of exchange between water and powdered quartz and microcline. Once again, the relative contributions of solid-state diffusion and recrystallization to the observed exchange rates are not known.

Haul and Dtimbgen (36) have employed isotopic exchange rates between oxygen and quartz, in the temperature range of $1010^{\circ} \mathrm{C}$ to $1220^{\circ} \mathrm{C}$, to obtain the following expression for the coefficient of diffusion of oxygen in quartz:

$$
D=3.7 \times 10^{-9} \exp (-55 \mathrm{kcal} / \mathrm{RT}) \mathrm{cm}^{2} / \mathrm{sec} .
$$

Extrapolating their data to $727^{\circ} \mathrm{C}$ by means of the above expression, a value of $3.7 \times 10^{-21} \mathrm{~cm}^{2} / \mathrm{sec}$ is obtained for D. Substituting this value into the equation describing the progress of diffusion in a cube, and using a solution given by Urey et al. (85), we find that $1 \mathrm{~mm}$ quartz crystals at $727^{\circ} \mathrm{C}$ should retain 90 percent of their original $0^{18}$ concentrations, relative to the equilibrium concentration of a changed environment, for a period of about 8 million years. 
In the presence of water the isotopic records may be erased more rapidly.

In view of our ignorance regarding the rates and durations of diffusion, the examination of natural systems may best decide the extent to which diffusion will prevent the application of isotopic techniques to geological thermometry. On the basis of this investigation it is possible to infer that the isotopic records established in quartz, garnet, magnetite, and ilmenite in the temperature range of $500^{\circ} \mathrm{C}$ to $600^{\circ} \mathrm{C}$ are fairly well-preserved in schists during the temperature decline following regional metamorphism. If this were not the case, the rather consistent relationships shown in figures 24 and 26 would not be expected. The rates at which the metamorphosed rocks cooled down are not known, though minimum rates can be deduced from the absolute ages of the metamorphic events investigated. The metamorphism in New England and Idaho culminated roughly $3.5 \times 10^{8}$ and $10^{8}$ years ago, respectively. [Long (52) and Hietanen (38).] 
CHAPTER III

\section{ANALYTICAL, TECHNIQUE}

\subsection{Mass spectrometry}

Isotopic analyses are performed on carbon dioxide gas. Carbon dioxide is less reactive than molecular oxygen, produces ion beams in a relatively clean portion of the mass spectrum, is readily manipulated in the vacuum apparatus, and is easily prepared from molecular oxygen. Schwander (68) used carbon monoxide, but this gas has the disadvantages of having a mass equal to that of nitrogen and being inseparable from nitrogen by freezing in liquid-nitrogen cold-traps. The fact that $\mathrm{CO}^{18}$ is one-half as abundant as $\mathrm{CO}^{18} \mathrm{O}^{16}$ reduces the precision with which the $0^{18} / 0^{16}$ ratio can be measured, and is another reason carbon monoxide is not preferred.

The mass spectrometer is a sixty degree deflection instrument of the type described by Nier (59) and McKinney et al. (56) employing a double-collector and a dual gas-feed system enabling the rapid comparison of a sample with a standard gas. The amplified voltage resulting from the mass-46 ion beam is balanced against that of the combined mass -44 plus mass -45 ion beams by means of a potential divider. The electronic circuitry is shown in schematic form in figure 1 .

Simultaneous collection of the two principal ion beams, together with rapid switching from sample to standard every 3 minutes, minimizes the effects of instrument variations. Each sample is run 
$-20-$

FIGURE 1

Electronic components of the double-collecting mass spectrometer 


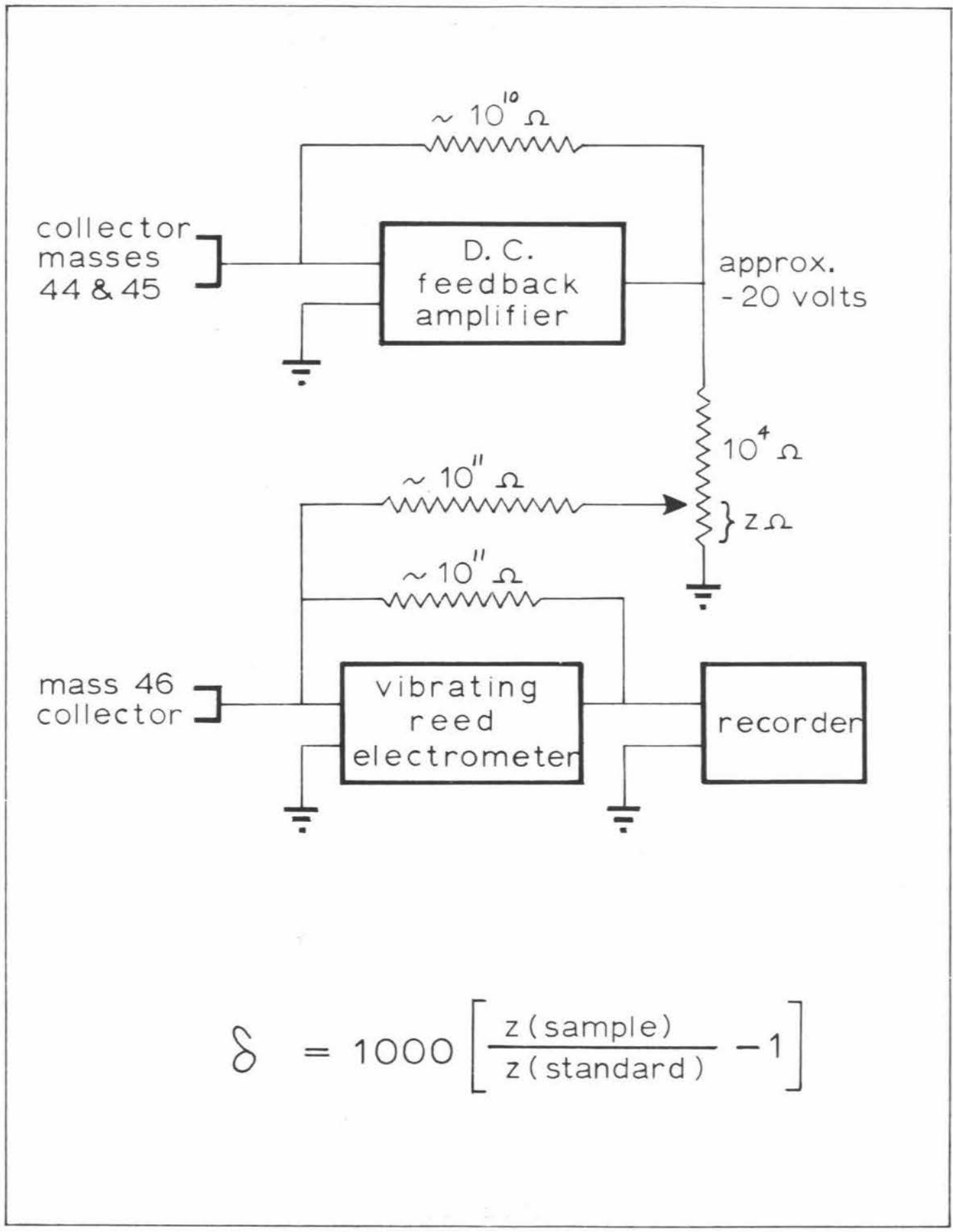

Figure 1 
twice, several days apart. Once every 20 samples, oxygen from a quartz standard (denoted by SPS) is extracted and converted to carbon dioxide. This is mun on the mass spectrometer once every 10 samples, or once every day.

The precision of the mass spectrometric technique is discussed in section 3.3 .

\subsection{Correction factors}

The ratio of masses as determined by the mass spectrometer is

$$
R_{46}=\frac{C^{12} o^{16} o^{18}+C^{13} 0^{16} o^{17}+c^{12} o^{17} o^{17}}{c^{12} 0^{16} o^{16}+c^{13} o^{16} o^{16}+c^{12} 0^{16} o^{17}},
$$

whereas the desired ratio is

$$
R_{18}=\frac{0^{18}}{0^{16}}=\frac{1}{2} \frac{c^{12} o^{16} o^{18}+c^{13} o^{16} o^{18}}{c^{12} o^{16} o^{16}+c^{13} o^{16} o^{16}} .
$$

From the relative abundances of the isotopic species in nature Craig (19) derived the following expression:

$$
\delta_{c}^{\prime}=1.0014 \delta_{m}^{\prime}+0.009 \delta^{\prime} c^{13}
$$

where

$$
\begin{aligned}
& 1+\delta_{m}^{\prime}=R_{46}(\text { sample }) / R_{46}(\text { standard }) \\
& 1+\delta_{C}^{\prime}=R_{18}(\text { sample }) / R_{18}(\text { standard }) \\
& 1+\delta^{\prime} C^{13}=C^{13} / C^{12}(\text { sample }) / C^{13} / C^{12}(\mathrm{PDB} \text { Standard })
\end{aligned}
$$

All the carbon dioxide samples in this investigation were produced from the same batch of graphite filaments and had a mean 
$\delta$ of -28.0 permil relative to the PDB Standard, with a mean deviation from this value of \pm 0.3 permil (5 analyses). The $\mathrm{C}^{13}$-correction, being constant, will affect the sample and standard equally, so that Craig's expression can be simplified to $\delta_{c}^{\prime}=1.0014 \delta_{m}^{\prime}$. Since the $0^{18} / 0^{16}$ ratio of the mass spectrometer standard gas is 25 permil larger than that of ocean water, the raw $\Delta$ values based. on this standard are less than the corresponding $\Delta$ values based on the ocean water standard, by a factor of 1.025 .

Another correction is necessitated by a long-lived background ion current of mass -44 which is about $3.5 \pm 0.5$ percent of the ion current obtained during normal gas feed. This background current remains fairly constant at this value for an hour following the closing of the valves and the removal of the sample and standard gases. The apparent $\delta$ for the background ion beams is approximately $-8 \pm 5$ permil relative to ocean water. This figure is an average of 4 determinations and is unreliable because of the necessarily low beam intensities employed during its measurement. But it serves to show that the background does not contribute disproportionately to the mass-46 beam. The long-lived background is assumed to be constant in quality and intensity, and a correction factor of 1.035 is applied to all analyses in order to compensate for the dilution effect of the background ion current.

Mixing of the sample and standard gases in the source, due to imperfect closure of the inlet valves, necessitates a correction factor of 1.004 . This is measured by noting the almost imperceptible 
shift of the null point when sample and standard gases, differing by about 20 permil, are alternately pumped away.

In order to investigate the possibility that one sample is contaminated by the sample preceding it in the extraction line and mass spectrometer, the measured differences between 10 suitable pairs of analyses of 10 mineral separates were compared with the analyses of the minerals extracted and run immediately before each member of the 10 pairs. The combined "memory" effect in the mass spectrometer and oxygen-extraction line was thereby found to be small, as is shown in table 1.

TABIE 1

Analyses showing extent of sample-sample contamination

\begin{tabular}{ccccc}
\hline \hline Sample Pair & $\Delta_{b}^{a}$ permil* & $\Delta_{d}^{c}$ permil** & Memory \%*** \\
\hline 531 & 532 & +0.02 & +12 & +0.2 \\
638 & 640 & +0.23 & +10 & +2.3 \\
663 & 672 & +0.40 & +12 & +3.3 \\
694 & 696 & +0.03 & +8.5 & +0.3 \\
760 & 763 & +0.08 & -8.2 & -1.0 \\
780 & 781 & +0.15 & +6.5 & +2.3 \\
789 & 790 & +0.06 & +10 & +0.6 \\
791 & 793 & +0.08 & -10 & -0.8 \\
801 & 823 & +0.27 & -13 & -2.1 \\
821 & 823 & +0.38 & +12 & +3.2 \\
\hline
\end{tabular}


*a and $b$ represent two extractions of the same mineral sample.

${ }^{*}{ }^{*} \mathrm{c}$ and $\mathrm{d}$ represent the samples immediately preceding $\mathrm{a}$ and $\mathrm{b}$ respectively.

****Memory is here defined by: $\Delta_{b}^{a} / \Delta_{d}^{c}$.

An additional correction factor arises from the contamination of each sample with the oxygen liberated from the walls of the reaction vessels. Six blank extractions yielded an average quantity of oxygen equal to $0.4 \pm 0.2$ percent of the amount usually extracted from a mineral. This contamination dilutes the oxygen samples and is compensated for by a correction factor of 1.004 .

The composite correction factor which is finally applied to the raw mass spectrometer data is 1.078 . This is the product of:

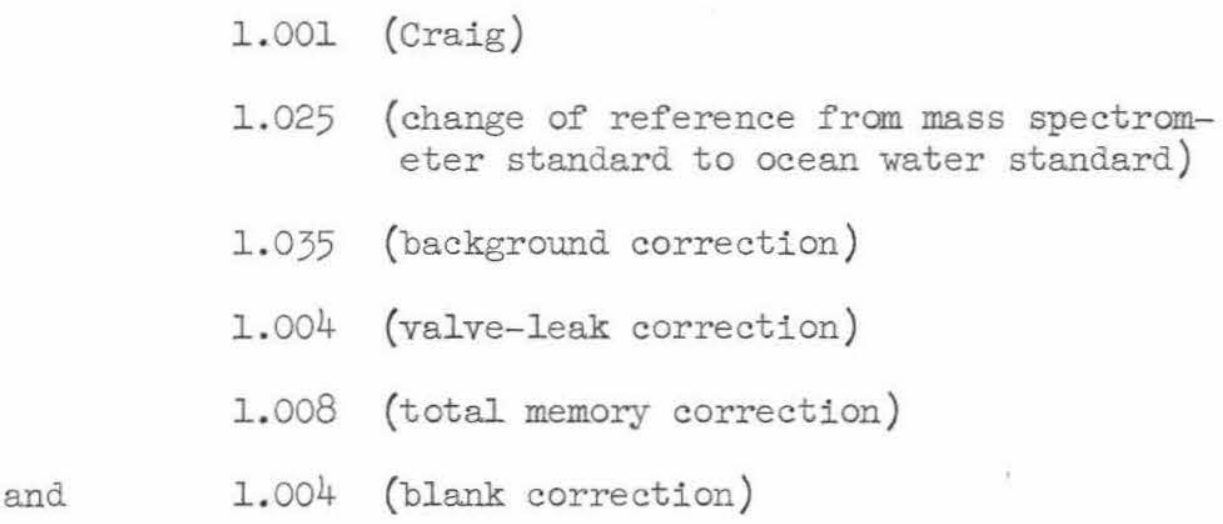

The first two of these correction factors are known to a high degree of accuracy. The remaining correction factors, of which the mass spectrometer background correction is the most important, are not as well known. The composite correction factor may be in error by as much as $1 \%$, which means that the reported fractionations between minerals may contain a systematic error of this magnitude. 


\subsection{Analytical precision}

The reproducibility of analyses on a single gas sample run at intervals of several days is approximately \pm 0.2 permil of the $0^{18} / 0^{16}$ ratio. However, the value of interest is $\delta-\delta$ (SPS), and the analytical error associated with this quantity is approximately \pm 0.1 permil when a single pair of gas samples is considered. The greater precision results from analyzing the sample and reference standard (SPS) on the same day, thereby reducing error due to instrument variations.

An additional error is associated with the oxygen-extraction technique, and the reproducability of the reported $\delta$ values is approximately \pm 0.2 permil. Since the minerals from a particular assemblage are usually analyzed on the same day, the precision of the reported fractionations between coexisting minerals is also about \pm 0.2 permil.

\subsection{Isotopic standards}

The basic isotopic standard is mean ocean water. Although differences in $0^{18} / 0^{16}$ ratio between water samples are conveniently measured to high accuracy by measuring $0^{18} / 0^{16}$ ratios of carbon dioxide equilibrated with water at $25^{\circ} \mathrm{C}$, the direct isotopic analysis of water is more difficult. Compston and Epstein (18) obtained quantitative oxygen yields from water by using the technique outlined by the following reactions: 


$$
\begin{gathered}
-27- \\
\mathrm{H}_{2} \mathrm{O}+\mathrm{xFe}+\mathrm{C} \stackrel{500^{\circ} \mathrm{C}}{\longrightarrow} \mathrm{Fe}_{\mathrm{x}} \mathrm{O}+\mathrm{H}_{2}+\mathrm{C} \\
\mathrm{Fe}_{\mathrm{x}} \mathrm{O}+\mathrm{C} \stackrel{1000^{\circ} \mathrm{C}}{\longrightarrow} \mathrm{xFe}+\mathrm{CO} \\
2 \mathrm{CO} \stackrel{\mathrm{Ni} \text { catalyst }}{\longrightarrow} \mathrm{C}+\mathrm{CO}_{2} .
\end{gathered}
$$

The fractionation factor for $\mathrm{CO}_{2}$-water at $25^{\circ} \mathrm{C}$ reported by Compston and Epstein is $1.0407 \pm 0.0003$. Because less circuitous methods for the isotopic analysis of water have not been perfected, Standard Mean Ocean Water is defined by:

$$
0^{18} / 0^{16}(\mathrm{SMOW})=0.98473 \times 0^{18} / 0^{16} \text { (Potsdam s.s. no. 2039). }
$$

It is on this basis that the $\delta$ of Potsdam s.s. no. 2039 is taken as $+15 \cdot 5$.

Craig (20) defined SMOW in terms of the National Bureau of Standard's isotopic reference water sample No. 1:

$$
\left.0^{18} / 0^{16}(\text { SMOW })=1.008 \times 0^{18} / 0^{16} \text { (NBS No. } 1\right) .
$$

Fortunately, as shown by Clayton (16), the two definitions of SMOW are almost identical.

The mass spectrometer working-standard used throughout this research is carbon dioxide derived from a laboratory prepared calcite, and has a $\delta$ value of approximately +25 permil relative to SMOW. The reference standard is a 230 to 310 micron size-fraction of st. Peter's sandstone obtained from Wards through McKinney, and is pure quartz with a $\delta$ value of $+10.9 \pm 0.1$ permil. The isotopic composition of this standard, denoted SPS, was established by comparing it with the 
Potsdam s.s. no. 2039 and St. Peter's s.s. no. 46 standards. See table 2 .

TABIE 2

Comparison of SPS with other standards

\begin{tabular}{|c|c|c|c|c|c|}
\hline Standard & $\begin{array}{l}\text { Reported } \\
(\operatorname{Ref} \cdot 1)\end{array}$ & $\begin{array}{c}\text { Values } \\
(\text { Ref. 2) }\end{array}$ & $\begin{array}{l}\text { Assumed } \\
\delta \text { value }\end{array}$ & $\triangle_{S T D}^{S_{S P}^{*}}$ & $\delta_{\text {SPS }}$ \\
\hline $\begin{array}{l}\text { Potsdam } \\
\text { no. } 2039\end{array}$ & $15.5 \pm .2(40)$ & $15 \cdot 5 \pm .3(9)$ & $15 \cdot 5$ & $-4.65 \pm .1 \quad(3)$ & 10.85 \\
\hline $\begin{array}{l}\text { St. Peters } \\
\text { no. } 46\end{array}$ & $11.1 \pm .2(9)$ & $11.0 \pm .2(13)$ & 11.05 & $-0.10 \pm .1 \quad(2)$ & 10.95 \\
\hline
\end{tabular}

Ref. 1 = Taylor and Epstein (74).

Ref. 2 = Clayton and Mayeda (16).

*This compilation includes only those extractions which yielded an amount of oxygen within 0.5 percent of the theoretical yield of $16.65 \mathrm{micromoles} / \mathrm{mgm}$.

The numbers in parentheses denote the numbers of analyses used in calculating the averages.

\subsection{Sample preparation}

Rocks to be analyzed are crushed in a steel mortar. The required particle size is usually in the range of 200 to 500 microns. Crushing is followed by screening to eliminate material finer than 100 to 200 microns in diameter, depending on the grain size of the rock. A Frantz Isodynamic magnetic separator, supplemented when necessary by heavy liquids, is used to separate the various mineral species from the crushed rock. 
Those minerals that require additional or special treatment are discussed below.

\section{a. Quartz}

Sinze quartz and oligoclase have similar densities and very low magnetic susceptibilities, it is usually necessary to clean the quartz by dissolving the contaminating feldspar in a solution consisting of 5 parts $38 \%$-fluoboric acid, 1 part phosphoric acid, and 1 part ferric chloride. Decomposition is usually complete after two days at $50^{\circ} \mathrm{C}$. Quartz is not appreciably affected by this treatment, unless it is severely strained, in which case it becomes slightly etched. Line and Aradine (51) assert that when quartz is ground to pass a 140 micron screen and subjected to a 24 hour attack with this reagent at $50^{\circ} \mathrm{C}, 0.34 \%$ of the quartz is dissolved. It is therefore unlikely that the process would appreciably alter the isotopic composition of the quartz. The isotopic effect was nevertheless checked by analyzing a pure quartz sample before and after one week of reaction with fluoboric acid at $50^{\circ} \mathrm{C}$. The average grain size of the sample was 400 microns. Two analyses before treatment yielded an average $\delta$ of $+3.6 \pm 0.1$ permil, whereas two analyses on the treated quartz yielded an average $\delta$ of $+3.5 \pm 0.1$ permil.

b. Garnet

Garnet is at least as refractory as magnetite in the presence of bromine pentafluoride. In order to render garnet less resistant to decomposition with bromine pentafluoride, it is fused in a vacuum to a black glass and crushed to pass a 50 micron nylon screen. In- 
complete oxygen yields from unfused garnet do not appear to result in markedly erroneous isotopic analyses, but residual garnet in the vessels after reaction is a possible source of contamination for the next sample.

Fusion is accomplished in induction-heated platinum crucibles at $900^{\circ} \mathrm{C}$ to $1000^{\circ} \mathrm{C}$. Weight loss after vacuum fusion is generally less than $0.2 \%$, and in part represents the loss of adsorbed water. The possibility that any ferric iron present in the garmet may be reduced to ferrous iron was discounted by fusing a green andradite-rich garnet from Graham County, Arizona, and observing a weight loss of less than $0.2 \%$, despite a little sputtering.

\section{c. Kyanite}

Since kyanite is exceptionally resistant to decomposition with bromine pentafluoride, it is fused in a vacuum at $1,600^{\circ} \mathrm{C}$ with diopside of known isotopic composition to yield a clear glass which reacts readily with the reagent. The quantities are chosen so that kyanite and diopside contribute equal amounts of oxygen to the final glass. Oxygen from the kyanite is thus diluted, and the determination of its isotopic composition is accordingly less accurate than that possible with other minerals. Only 3 kyanite samples were analyzed. The isotopic composition of the diopside used was within 3 permil of the kyanite compositions.

\section{d. Ilmenite}

Ilmenite is crushed to pass a 50 micron nylon screen, and is then adequately amenable to fluorination. 


\section{e. Magnetite}

To obtain magnetite, the rocks are first crushed on a mullite plate with a mullite hammer. The magnetite is picked up magnetically and ground in an agate mortar to pass a 50 micron nylon screen. The fine powder is further cleaned by means of a hand magnet.

Magnetite samples vary appreciably in their amenability to fluorination. Reaction rate probably increases with titanium content, but other factors are undoubtedly involved.

\subsection{Sample-contamination corrections}

All mineral separates were checked for purity under a binocular microscope. Contamination of one mineral by another was rarely found to be serious, except in the case of quartz contaminating magnetite or ilmenite. Consequently, all magnetite and ilmenite separates were analyzed by means of an X-ray diffractometer equipped with a Geiger-Mueller counter. Iron-filtered cobalt $\mathrm{K}_{\alpha}$ radiation was used, and the intensity of the principal reflection of magnetite or ilmenite was compared with that of the contaminating quartz. Standards prepared from magnetite, ilmenite and quartz were used to calibrate the $\mathrm{X}$-ray reflection intensities. The precision of this technique is approximately $0.5 \%$ quartz by weight, which corresponds to an isotopic effect of about 0.1 permil, which is within analytical error. The maximum content of extraneous quartz encountered was 3 wt. $\%$, necessitating a 0.6 permil correction to the determined isotopic composition of a magnetite sample. A reflection of low intensity corresponding to a spacing of $2.425 \AA$ was detected in magnetite samples: 
D6, D7, D47, EV18, IA33, and RCC. An effort to identify the mineral causing this reflection was unfruitful.

\subsection{Oxygen extraction}

a. Apparatus

The high-vacuum apparatus is composed of two essential sections, one metal, the other glass, and is shown schematically in figure 2. The metal section, consisting of Inconel tubing, Monel Hoke valves, Monel flanges, silver-soldered copper fittings, Teflon gaskets, pure nickel welded-reaction-vessels, a Kel-F reagent reservoir, and a Bourdon-type vacuum gauge with Monel diaphragm, is similar to that described by Clayton and Mayeda (16). The glass section is similar to that described by Taylor and Epstein (74), employing a Toepler pump, mercury manometer, and resistance-heated carbon filament. The high vacuum is obtained with a mercury diffusion pump backed by a Welch Duoseal mechanical pump. The automatic Toepler pump is operated through an electrical relay by another Duoseal pump. At other times this same pump is used to produce a rough vacuum in the waste system. The traps are cooled with liquid nitrogen.

\section{b. Analytical procedure}

Following the complete reaction and collection of one set of samples, the reaction vessels and flanges are out-gassed at $80^{\circ} \mathrm{C}$ under high vacuum for one hour. Dry nitrogen is then slowly introduced through the waste trap until the pressure in the reaction vessels is one atmosphere. The reaction vessel valves are then closed and the manifold is detached and transferred to a glove-box in which the air 
$-33-$

FIGURE 2

Apparatus for the extraction of oxygen from minerals and its conversion to carbon dioxide 


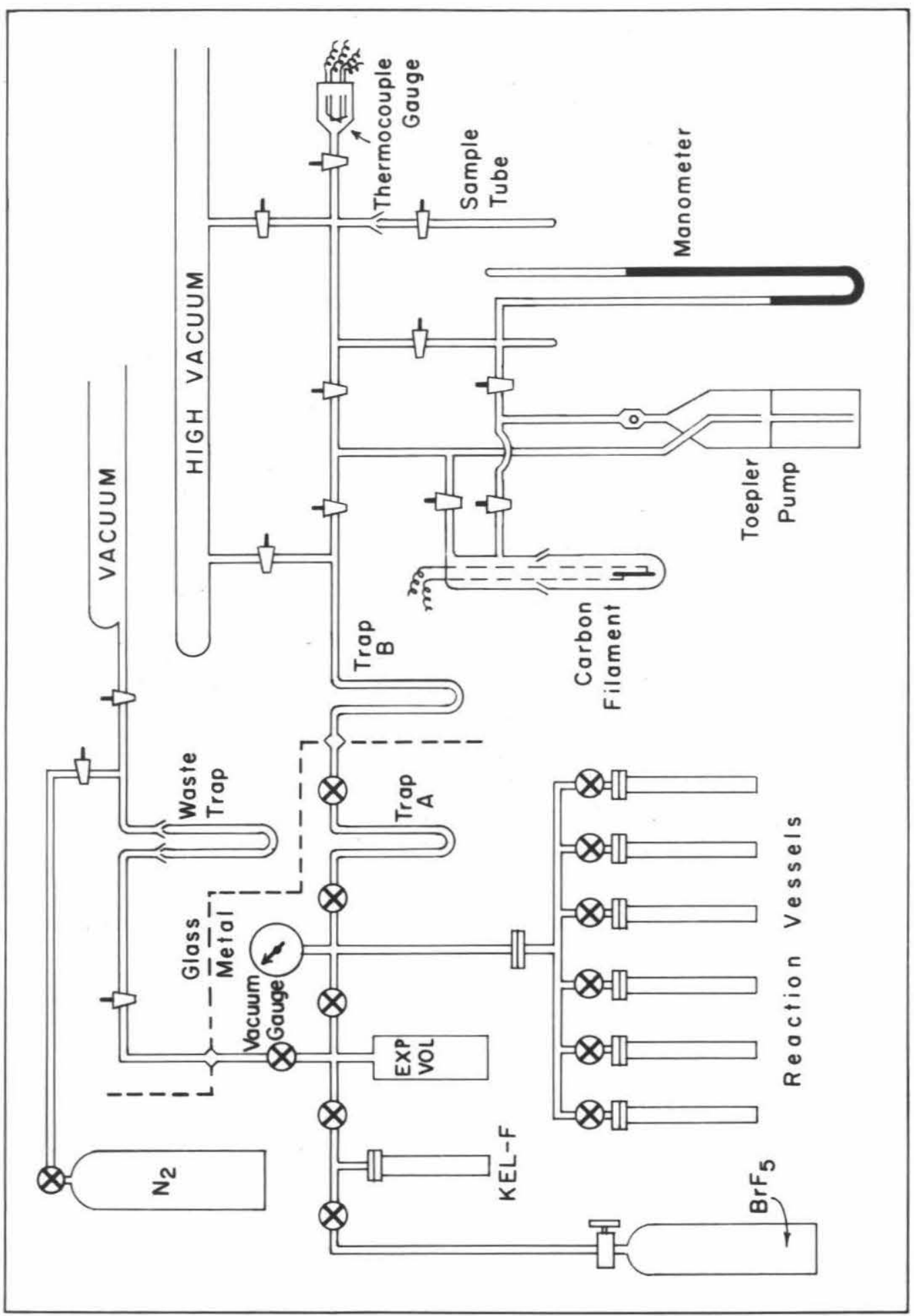

Figure 2 
is dried by circulation over powdered phosphorus pentoxide. When the humidity is near zero each reaction vessel is opened, the residue from the previous sample is gently tapped out, and a new sample is introduced with long forceps to guarantee its placement near the bottom of the tube. The weighing pan is withdrawn and is later reweighed if any powder remains attached to it. The quantity of sample introduced is chosen to yield about 500 micromoles of oxygen and ranges from about $30 \mathrm{mgm}$ of quartz to $60 \mathrm{mgm}$ of magnetite. After the vessels are securely bolted back onto the manifold, they are returned to the vacuum line and evacuated. The metal line, excluding the reaction vessels, is refluorinated at $80^{\circ} \mathrm{C}$ for 5 minutes, after which the reaction vessels are evacuated under high vacuum at $90^{\circ} \mathrm{C}$ for 30 minutes.

Prefluorination of the reaction vessels was avoided because feldspars and certain hydrous silicates react at temperatures less than $100^{\circ} \mathrm{C}$, and once a procedure suitable for all minerals was established, departures from this procedure were maintained at a minimum.

Following the outgassing period, the manifold valves are closed, the reaction vessels are cooled with liquid nitrogen, and 5 millimoles of bromine pentafluoride, representing a 5-fold stoichiometric excess, are frozen into each reaction vessel. This is achieved by expanding the reagent from the Kel-F reservoir into an expansion volume of $280 \mathrm{cc}$, until a pressure of $30 \mathrm{~cm} . H \mathrm{Hg}$ is obtained on the vacuum gauge, after which one of the reaction vessel valves is opened. 
The system is opened to high vacuum briefly, in order to remove any traces of non-condensible gas, before each reaction vessel is finally closed.

The reaction vessels are individually heated with wire-wound electric resistance furnaces to $550^{\circ} \mathrm{C}$ or $620^{\circ} \mathrm{C}$, as measured by Chromel-Alumel thermocouples in light contact with the lower portions of the reaction tubes. A temperature of $620^{\circ} \mathrm{C}$ is required for the fluorination of magnetite; $550^{\circ} \mathrm{C}$ is sufficient for the other materials used in this study. Above $620^{\circ} \mathrm{C}$, decrepitation of the nickel fluoride coating takes place and the consumption of reagent by the reaction vessels is excessive.

The Teflon gaskets are maintained at a temperature of about $50^{\circ} \mathrm{C}$ during the reaction by a constant flow of water through copper coils soldered to the vessels just below the flanges.

The fluorination of most minerals is quantitative after 8 hours, though magnetite usually requires approximately 15 hours for complete reaction. Prior to collection of the oxygen, the reaction vessels are allowed to cool to room temperature. The reaction products in one tube are expanded into the section of line containing the vacuum gauge and the resulting pressure is noted. (The presence of excess reagent at this time is essential.) The Monel valves to the right of the vacuum gauge are then opened sufficiently to permit the gas mixture to flow slowly through the two liquid-nitrogen traps and into the Toepler pump. Oxygen, with a vapor pressure of $170 \mathrm{~mm} . \mathrm{Hg}$ at $-195.8^{\circ} \mathrm{C}$, is the only gas to reach the Toepler pump. The reaction 
products and excess reagent have vapor pressures of less than $10^{-6} \mathrm{~mm} . \mathrm{Hg}$ at the temperature of liquid nitrogen, and remain in the metal trap. The amount of oxygen entrained in the metal trap was checked, and found to be less than one micromole, even when the reaction products were frozen in an environment of oxygen at a pressure of $2 \mathrm{~cm} \cdot \mathrm{Hg}$. The Toepler pump transfers the oxygen directly to a vessel containing a red-hot, resistance-heated, graphite filament. The $0.3 \mathrm{~cm}$ diameter graphite filament is attached to platinum electrodes which are silver-soldered to tungsten rods passing through the glass envelope. The glass tube enclosing the graphite filament is cooled with liquid nitrogen and condenses the carbon dioxide resulting from the combustion of the graphite, thus forcing the reaction to completion. Taylor (73) showed that a kinetic fractionation accompanies the conversion of oxygen to carbon dioxide, and is of a magnitude in keeping with the expectation that the various isotopic molecules are converted in proportion to their frequency of collision with the graphite. The last oxygen to be converted is enriched in the heavy isotope in accordance with the Rayleigh equation:

$$
\frac{0^{18} / 0^{16}\left(\text { Residual } \mathrm{O}_{2}\right)}{0^{18} / 0^{16}\left(\text { Initial } \mathrm{O}_{2}\right)}=(\text { Fraction remaining })^{\alpha-1} \text {, }
$$

where

$$
\alpha=\sqrt{32 / 34} \text {. }
$$

However, this effect is not a problem because the conversion of oxygen to carbon dioxide is carried to completion and the final vacuum is always checked with a Tesla-coil discharge. 
Collection of the oxygen from the reaction vessel is complete within 30 minutes, the Monel valve between the metal and glass traps having been progressively opened as the gas pressure decreased. The conversion of oxygen to carbon dioxide is accomplished during collection. Once the oxygen is converted to carbon dioxide, the graphite filament is cooled to about $100^{\circ} \mathrm{C}$, the glass envelope is warmed, and the gas is refrozen into the manometer.

While the manometer is warming to room temperature, the metal line is opened to the high vacuum in preparation for the next extraction routine.

The glass tube in which the carbon dioxide samples are transferred to the mass spectrometer are outgassed for at least 30 minutes before being refilled.

The contents of the metal trap are removed to the waste trap after three extractions, in order to prevent its blockage.

The graphite filament is renewed after 12 samples, and is outgassed at about $800^{\circ} \mathrm{C}$ for 5 minutes before use.

\subsection{Analytical precautions}

a. Quartz

Serious errors can occur when the oxygen yields from a mineral are not quantitative. Of those minerals studied, quartz was found to be the most susceptible to this kind of error.

Low yields caused by inadequate reaction temperatures or reaction times result in anomalously low $0^{18} / 0^{16}$ ratios. Low yields 
caused by insufficient reagent result in anomalously high $0^{18} / 0^{16}$ ratios. Data pertaining to the relationship between oxygen yield and isotopic composition are presented in table 3 and figure 3 . The two points marked by squares in figure 3 were accurately checked by material-balance calculations, based on the quantity and composition of oxygen obtained after refluorinating the reaction vessels with excess reagent. Since refluorination liberates the remaining oxygen, it is evident that it resides in the reaction vessels in forms with negligible vapor pressures at room temperature.

Yields were noticeably deficient when the final mole-ratio of excess reagent to liberated oxygen fell below 1.5. See table 4 . The residual amounts of $\mathrm{BrF}_{5}$ reported in the table were calculated from the observed pressures of the reaction gases after cooling and expansion into the manifold. $\mathrm{Br}_{2}$ was assumed to be absent, $\mathrm{SiF}_{4}$ and $\mathrm{O}_{2}$ were assumed to be present in equal mole proportions, and the vapor pressure of $\mathrm{BrF}_{3}$ was taken to be $0.5 \mathrm{~cm} . \mathrm{Hg}$ at room temperature.

Quantitative yields from ilmenite were obtained when the final mole ratio of $\mathrm{BrF}_{5}$ to $\mathrm{O}_{2}$ was as low as $0.03 \pm 0.03$. Perhaps the phenomenon of low oxygen yields in the presence of $\mathrm{BrF}_{5}$ is dependent upon the presence of silicon.

Taylor (personal communication) has investigated the relationship between measured $0^{18} / 0^{16}$ ratios and oxygen yields obtained from quartz using fluorine. The isotopic effects of using insufficient fluorine are about a tenth as large as the effects resulting from the use of insufficient $\mathrm{BrF}_{5}$. 
TABIE 3

Isotopic effects of low oxygen yields from quartz

\begin{tabular}{|c|c|c|c|c|c|c|}
\hline $\begin{array}{l}\text { Quartz } \\
\text { Sample }\end{array}$ & $\begin{array}{l}\text { Grain } \\
\text { Size } \\
\text { Microns }\end{array}$ & $\begin{array}{l}\text { Reaction } \\
\text { Temp. } \\
\text { Deg. Cent. }\end{array}$ & $\begin{array}{l}\text { Reaction } \\
\text { Time } \\
\text { Hours }\end{array}$ & $\begin{array}{l}\text { Oxygen } \\
\text { Yield } \\
\text { Percent }\end{array}$ & $\begin{array}{c}\delta \\
\text { Permil }\end{array}$ & Comment s* \\
\hline D52 & 250 & 550 & 12 & 100 & +11.7 & $\mathbb{N}$ \\
\hline$"$ & $"$ & $"$ & 18 & 92 & +13.6 & R \\
\hline$"$ & $"$ & $"$ & 8 & 8 & -10.3 & S \\
\hline SPS & $"$ & $"$ & 20 & 92 & +12.7 & $\mathrm{R}$ \\
\hline$"$ & 50 & $"$ & 15 & 85 & +14.0 & $\mathrm{R}$ \\
\hline$"$ & 250 & $"$ & $"$ & 65 & +20.0 & R \\
\hline$n$ & $"$ & 500 & 20 & 52 & +28.1 & $\mathrm{R}$ \\
\hline$"$ & $"$ & 400 & 15 & 65 & +4.1 & $\mathrm{~T}$ \\
\hline$"$ & $"$ & 500 & 8 & 35 & +23.4 & $\mathrm{~S}$ \\
\hline$"$ & 250 & 400 & 15 & 82 & +5.7 & $\mathrm{~T}$ \\
\hline Pot.ss. & 50 & $"$ & 10 & 87 & +9.7 & $\mathrm{~T}$ \\
\hline$"$ & $"$ & $"$ & $n$ & 83 & +8.4 & T \\
\hline$"$ & $"$ & $"$ & $"$ & 81 & +8.0 & $\mathrm{~T}$ \\
\hline$"$ & $"$ & $"$ & 1 & 72 & +8.2 & $T \& R$ \\
\hline$"$ & $"$ & 350 & 14 & 53 & +6.8 & $\mathrm{~T}$ \\
\hline
\end{tabular}

${ }^{*} \mathbb{N}=$ normal run

$R=$ deficient reagent

$T$ = inadequate time or temperature

$\mathrm{S}=$ second reaction to check residual oxygen 
$-41-$

FIGURE 3

Isotopic effects of deficient oxygen yields from quartz when using $\mathrm{BrF}_{5}$ as reagent 


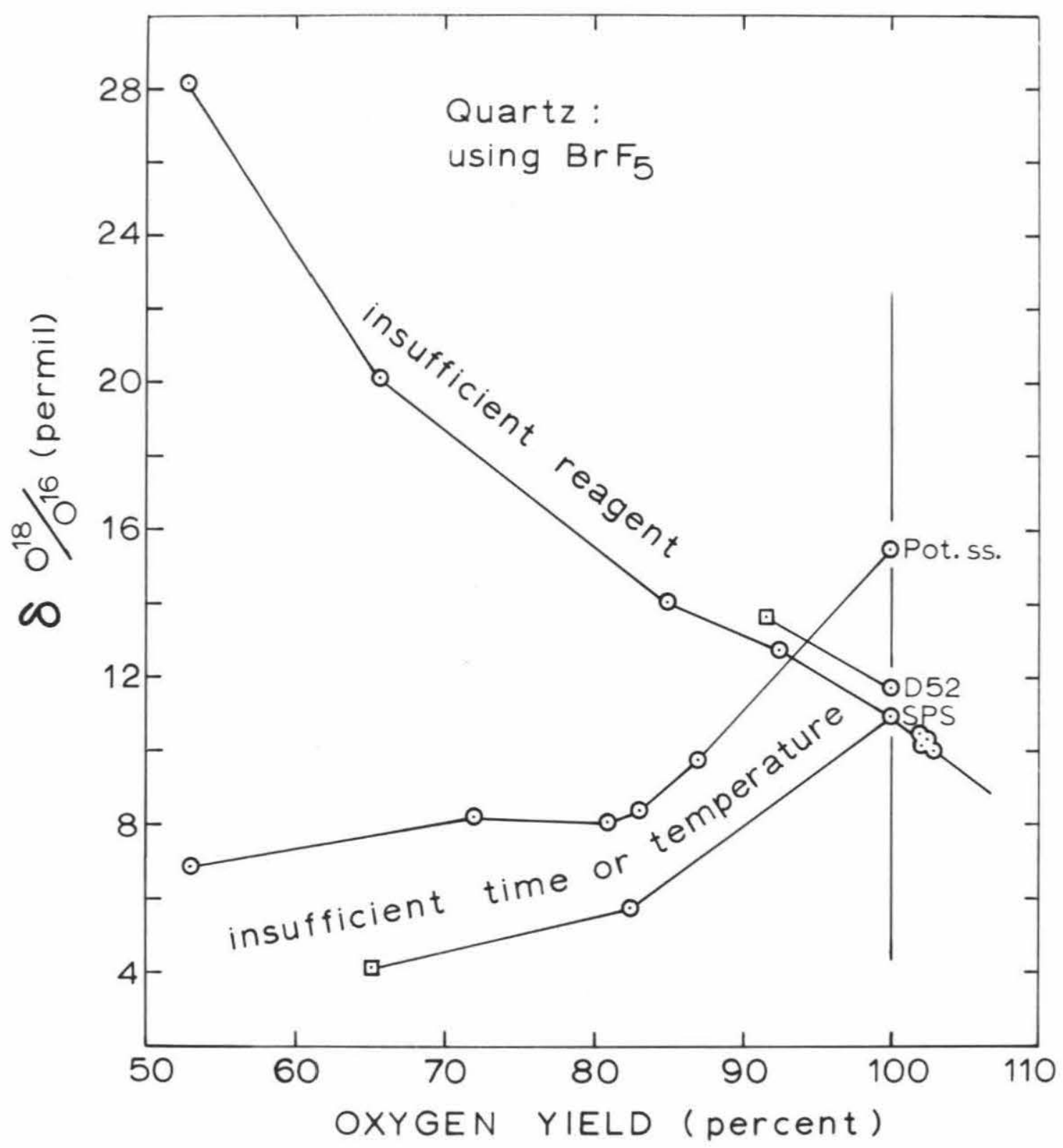

Figure 3 
TABIE 4

oxygen yields related to reagent excess

\begin{tabular}{lcc}
\hline \hline $\begin{array}{c}\text { Run } \\
\text { Number }\end{array}$ & $\begin{array}{c}\text { Oxygen Yield, } \\
\text { of Theoretical }\end{array}$ & $\begin{array}{c}\text { Final } \\
\mathrm{BrF}_{5} / \mathrm{O}_{2} \text { Ratio }\end{array}$ \\
\hline 505 & 100.4 & 1.5 \\
615 & 95.5 & 1.3 \\
817 & 91.2 & 0.2 \\
\hline
\end{tabular}

The consumption of bromine pentafluoride by the nickel reaction tubes is largely unpredictable, and increases markedly with temperature. Therefore, an initial excess of reagent does not insure a complete oxygen yield. It is advisable to check the content of reagent in the reaction products before collection and conversion of the oxygen.

Low yields due to inadequate temperatures were not a problem during the routine stage of this research. But low yields due to insufficient reagent recurred on several occasions, particularly after cleaning and polishing the interiors of the reaction vessels, and before a stable coating of nickel fluoride was re-established.

\section{b. Garnet}

Unfused garnets require high temperatures in the vicinity of $600^{\circ} \mathrm{C}$, for complete fluorination, but do not cause undue difficulties. Under identical conditions, fused garnets are noted to yield more oxygen than unfused garnets, but the resulting analyses are similar: 


\section{TABIE 5}

Comparison of isotopic analyses and oxygen yields

from fused and unfused garnet

\begin{tabular}{lcccr}
\hline \hline $\begin{array}{c}\text { Garnet } \\
\text { Condition }\end{array}$ & $\begin{array}{c}\text { Reaction } \\
\text { Temp. } \\
\text { Deg. Cent. }\end{array}$ & $\begin{array}{c}\text { Reaction } \\
\text { Time } \\
\text { Hours }\end{array}$ & $\begin{array}{c}\text { Yield } \\
\text { micromoles } \\
\text { per mgm }\end{array}$ & permil \\
\hline $\begin{array}{c}\text { unfused } \\
50\end{array}$ & 550 & 20 & 7.0 & +10.75 \\
$\begin{array}{c}\text { unfused } \\
50\end{array}$ & 575 & 20 & 9.6 & +10.70 \\
fused & 50 & 20 & 12.6 & +10.81 \\
50 & 575 & & & \\
\hline
\end{tabular}

The theoretical yield, calculated from a wet chemical analysis, is 12.5 micromoles per milligram.

In another run on the fused garnet sample the reagent was deficient, having reacted with the nickel reaction vessel. The resulting analysis was reminiscent of quartz analyses associated with deficient yields caused by deficient reagent. The oxygen yield was $69 \%$ of the theoretical yield and the $\delta$ value of the oxygen was 3.7 permil larger than normal. This error is half that expected for a relative yield of similar magnitude from quartz.

\section{c. Magnetite}

Magnetite is rather resistant to complete decomposition with bromine pentafluoride, even when ground to less than 50 microns and reacted at $600^{\circ} \mathrm{C}$ for 18 hours. The isotopic fractionations resulting from deficient oxygen-yields were therefore investigated. 
TABLE 6

Isotopic effects of low oxygen yields from magnetite

\begin{tabular}{lcccc}
\hline \hline $\begin{array}{c}\text { Run } \\
\text { No. }\end{array}$ & $\begin{array}{c}\text { Yiela } \\
\% *\end{array}$ & permil & $\begin{array}{c}\text { Quartz \& Blank } \\
\text { Contamination } \\
\text { Correction** }\end{array}$ & $\begin{array}{c}\text { Difference: } \\
\Delta_{\mathrm{b}}^{*}\end{array}$ \\
\hline la & 87 & +5.3 & -0.1 & +0.2 \\
$1 \mathrm{~b}$ & $\frac{12}{99}$ total & +5.0 & 0 & \\
$2 \mathrm{a}$ & 63 & +5.4 & -0.1 & +0.6 \\
$2 \mathrm{~b}$ & $\frac{33}{96}$ total & +4.7 & 0 & \\
$3 \mathrm{a}$ & 57 & +5.2 & -0.1 & +0.2 \\
$3 \mathrm{~b}$ & $\frac{21}{78}$ total & +4.9 & 0 & \\
\hline
\end{tabular}

*Theoretical oxygen yield $=8.62 \mu$ moles per mgm.

**oxygen from quartz impurities and reaction vessel walls is assumed to contaminate only the first collection of oxygen.

From the data in table 6 it appears that the isotopic composition of oxygen derived from magnetite becomes lighter as the reaction progresses; however, the effect is small, and may be neglected if yields are greater than $95 \%$ of theoretical.

\section{d. Reactivity of minerals}

Low reaction rates with minerals such as magnetite, olivine, kyanite, garnet, epidote, and chloritoid have been attributed to the armoring effect of nonvolatile iron, magnesium, aluminum, and calcium 
fluorides [Taylor and Epstein (74)]. Crystal structure may also be important in determining the reactivity of the minerals [Sharma (70)]. All the silicates listed above contain isolated silica tetrahedra, rather than the chain, sheet, and network structures which occur in less refractory minerals. On the other hand, Taylor and Epstein point out that sphene and zircon, having structures of independent silica tetrahedra, are not difficult to react.

\section{e. Excessive yields}

Excessive oxygen yields were obtained if the relative humidity in the glove-box was not near zero during the loading operation. Fluoride coatings on silver solder were observed to be very hygroscopic, and the solder between the flange and monel valve is the probable location of the absorbed water. Table 7 and figure 3 show the effect of excess yield on the isotopic composition of the oxygen collected. The samples used in the compilation are all quartz samples with compositions within 2 permil of SPS. The anomalous analyses were omitted in calculating the $\delta$ (average) values. The gradient of $\delta$ versus yield indicates an isotopic composition for the absorbed water of -20 permil relative to ocean water. 
TABIE 7

Analytical errors resulting from excessive oxygen yields

\begin{tabular}{|c|c|c|c|c|}
\hline $\begin{array}{c}\text { Oxygen Yield } \\
\text { percent }\end{array}$ & $\delta$ (average) & \multicolumn{3}{|c|}{ Comments } \\
\hline 102.0 & -0.5 & moist & glove & box \\
\hline 102.5 & -0.9 & $"$ & $"$ & $"$ \\
\hline 102.5 & -0.7 & $"$ & $"$ & $"$ \\
\hline 103.0 & -0.9 & $"$ & $"$ & $"$ \\
\hline
\end{tabular}

\section{f. Yield corrections}

A few quartz analyses were salvaged by applying a correction for anomalous yields within 1.0 percent of the theoretical yield. The magnitudes of these corrections as determined by the slopes of the appropriate curves in figure 3 are:

$$
\begin{aligned}
& -0.2 \text { permil per } 1 \% \text { oxygen deficiency; } \\
& +0.3 \text { permil per } 1 \% \text { oxygen excess. }
\end{aligned}
$$

\subsection{Relative merits of $\mathrm{BrF}_{5}$ and $\mathrm{F}_{2}$}

Oxygen-extraction techniques employing fluorine or bromine pentafluoride have been found to be the most successful for oxides and silicates.

The advantages of using $\mathrm{BrF}_{5}$ rather than $\mathrm{F}_{2}$ have been discussed by Clayton and Mayeda (16), and will not be repeated here.

The use of $\mathrm{BrF}_{5}$ has one serious disadvantage in that large analytical errors accompany incomplete oxygen yields from quartz. 
$-48-$

Precautions must therefore be taken to insure complete fluorination. The most important requirement, as discussed previously, is a large excess of reagent. 


\subsection{Concept of metamorphic grade}

Since we are concerned with the isotopic behavior of oxygen in metamorphic rocks and minerals, it is advisable to review briefly the terminology and petrogenetic theory applied to such rocks.

Metamorphic rocks are graded according to the mineral facies concept of Eskola (29). A mineral facies is bounded by isograds. An isograd may be defined as a surface in the earth's crust on which one degree of freedom in choosing the intensive variables, pressure ( $P$ ), temperature ( $T$ ), and the chemical potentials of the mobile components $\left(\mu_{m_{i}}\right)$, has been lost as a result of the appearance of an additional stable phase, termed an index mineral. Within the volume bounded by such isograds, $f=2+m$, and Korzhinsky's phase rule holds: $p=c-m$, where $f$ is the number of degrees of freedom, $p$ is the number of phases present, $\mathrm{m}$ is the number of components whose chemical potentials are externally controlled, and $c$ is the total number of independent components necessary to specify the chemical composition of the rock. The number 2 signifies that pressure and temperature are independent variables within the volume.

The classification of a rock into a particular grade or facies presumes that mineralogical equilibrium was attained under a particular set of conditions. 
Following the terminology of Bowen (10) and Thompson (77), the curves of univariant equilibrium on a P, T diagram may be regarded as a "petrogenetic grid" defining the mineral facies for a given petrologic system.

\subsection{Equilibrium mineral assemblages}

Since the majority of rocks examined in this work are pelitic schists containing muscovite and quartz, the use of Thompson projections (78) to represent the phase equilibria is convenient. Rock compositions are plotted in a tetrahedron with respect to the four critical components, $\mathrm{Al}_{2} \mathrm{O}_{3}, \mathrm{~K}_{2} \mathrm{O}, \mathrm{FeO}$, and $\mathrm{MgO}$, denoted by "A-K-F-M." The point corresponding to muscovite is then used as a source from which to project the rock composition onto the "A-F-M" face and its extension. Examples of the resulting diagrams are given in the appendix of rock descriptions. The topology and distribution of the stability fields of the various minerals in such diagrams are determined in large part by $P, T$ and $\mu_{\mathrm{H}_{2}} \mathrm{O}$.

Phase assemblages which appear to be incompatible with the phase diagram are occasionally observed in a single hand specimen. For example, quartz, muscovite, garnet, staurolite, chlorite, and biotite are found within a few millimeters of one another in rock AH2096, the probable phase relations of which are shown in the appendix. Such anomalies may result from one or more of the following conditions: 
1. The rock is chemically inhomogeneous on a scale larger than that in which mineralogical equilibrium is achieved.

2. The rock crystallizes at the particular $P, T$ and $\mu_{\mathrm{H}_{2} \mathrm{O}}$ corresponding to a reaction surface.

3. The rock is closed to water, and thus invalidates the assumption that the chemical potential of water is extemally controlled.

4. The additional phase is stabilized by a component or components other than those already considered.

5. The distribution of the five-phase stability fields vary during crystallization due to changes in $P, T$, or $\mu_{\mathrm{H}_{2}} \mathrm{O}$, and early-formed assemblages are preserved in the presence of laterformed assemblages.

If the first condition obtains, and if one wishes to analyze an equilibrium assemblage, one should separate the minerals from as small a volume as possible. If the explanation lies in the last possibility, the rock is everywhere out of mineralogical equilibrium, and isotopic equilibrium will be least likely to prevail. The remaining possibilities do not constitute threats to the achievement and retention of isotopic equilibrium.

\subsection{Preservation of high-temperature assemblages}

The retention of isotopic compositions in the minerals of regionally metamorphosed rocks is dependent on the persistence of high-temperature assemblages during the temperature decline following 
the peak of metamorphism. Fortunately, extensive retrograde effects are seldom seen in the mineralogy of rocks which have experienced only one episode of metamorphism.

The apparent stability of high-temperature assemblages is in part due to the increase in grain size accompanying metamorphism. Because solid-state diffusion is generally a slow process, the rates of inhomogeneous reactions are often proportional to the surface area available for reaction, and the increase in grain size reduces the surface area of the minerals.

Perhaps the most important factor preventing retrogradation is the loss of water during progressive metamorphism. Dehydration reactions are, of course, irreversible in the absence of water. Moreover, water is not only an essential ingredient in many metamorphic reactions, but also plays the vital role of solvent. Other factors of possible significance in preserving the high-temperature assemblages are discussed by Fybe and Verhoogen (32). Two processes of retrogradation should be distinguished:

1. Reactions that change the kinds of phases present;

2. Recrystallization of existing phases. The first type of retrogradation can often be recognized in thin section, but recrystallization may pass unnoticed and lead to confused interpretations of the isotopic data. 


\section{CHAPTER V}

\section{GEOLOGY AND ISOTOPIC RESULTS OF INDIVIDUAL AREAS}

\subsection{Dutchess County, southeasterm New York}

\section{a. Metamorphic geology}

The metamorphism and structure of the rocks in Dutchess County, southeastern New York, have been described by Barth (5) and Balk (4), respectively. Their geological map has been slightly revised by Carroll (12) and Rodgers et al. (63). The following description is largely based upon the published work of Barth.

Early Paleozoic argillaceous sediments, interbedded with lenses of conglomerate, arkose, greywacke and thick carbonate units, strike north-south and exhibit an increasing metamorphic grade when traced across strike from west to east. The sequence is intermpted by one major north-south thrust fault, the Chestnut Ridge fault, located between Clove Valley and Harlem Valley. Average grain size increases from west to east, experiencing an abmut change across the Chestnut Ridge fault. The biotite, garmet, and sillimanite isograds are shown in figure 4.

Black or olive-grey argillites near the western edge of the map grade eastward into lustrous phyllites containing recrystallized muscovite. Continuing eastward, one finds phyllites containing biotite in addition to muscovite. All rocks are entirely recrystallized on the high grade site of the biotite isograd. Muscovite and biotite remain stable and abundant up to the highest grades of metamorphism. 
FIGURE 4

Map showing the metamorphic geology and sample locations in Dutchess County and vicinity. [After Balk (4), Barth (5), Carrol (12), and Rodgers et al. (63)]. 


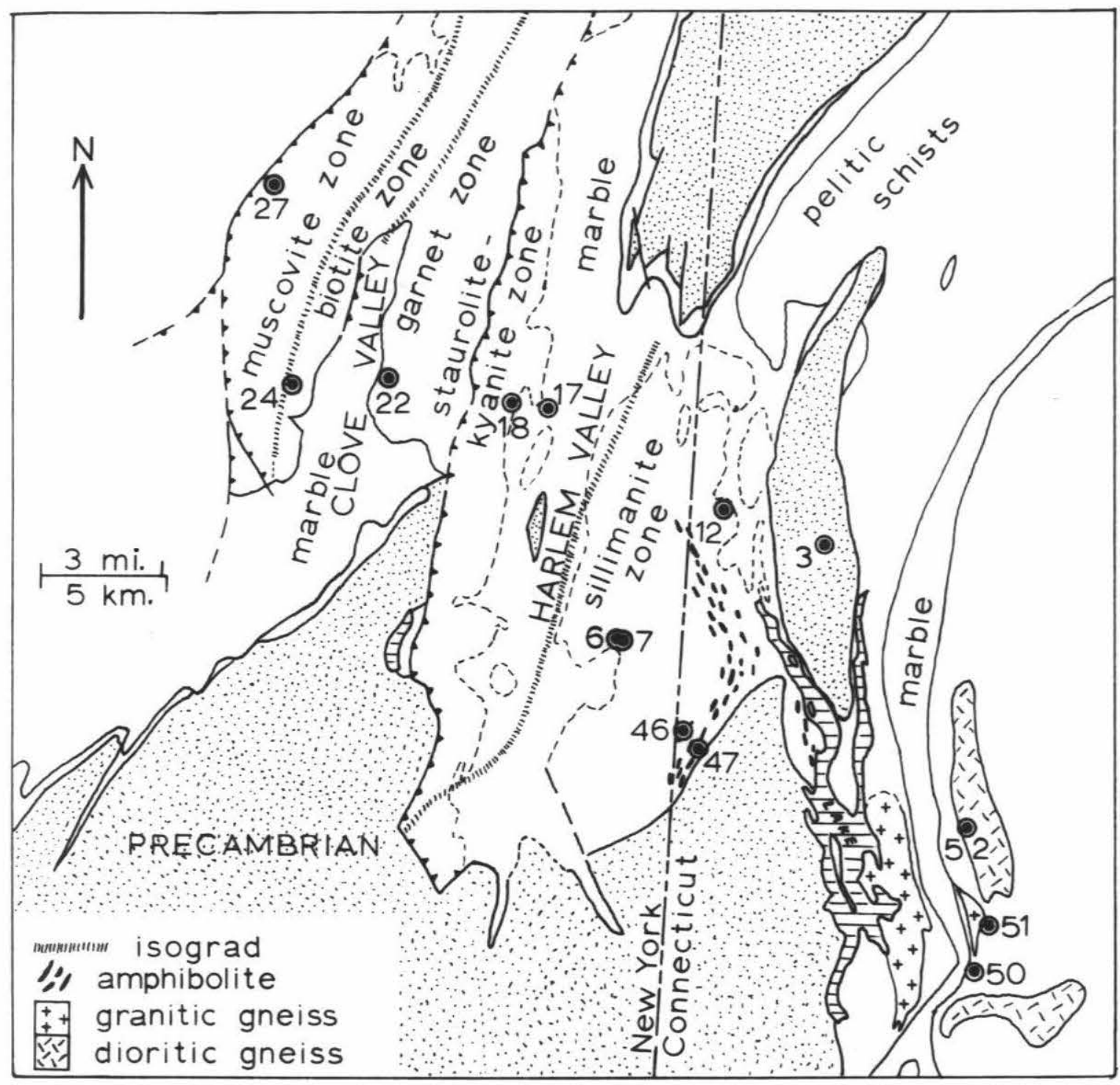

Figure 4 
The biotite exhibits colorless to reddish-brown pleochroism, and there is no apparent systematic change in color with increasing metamorphisms. Nine chemical determinations, reported by Barth, of the iron to magnesium ratio also fail to reveal any systematic change with grade.

Immediately to the east of Clove Valley the schists contain porphyroblasts of almanditic garnet, and garnet persists to the highest grades of metamorphism.

Metacrysts of staurolite and kyanite appear a few kilometers east of the gamet isograd. Staurolite is abundant between the Chestnut Ridge fault and Harlem valley, but kyanite is fairly rare. Chloritoid is found on the east slope of clove Valley where it replaces staurolite, the ragged remnants of which can often be observed in thin section.

The sillimanite isograd, representing the transition of kyanite to sillimanite, is drawn just east of Harlem Valley in the north and just west of the valley in the south. Staurolite persists some distance into the sillimanite zone and has been observed $2.5 \mathrm{~km}$. east of the sillimanite isograd in rocks D6 and D7. Rock D12 contains sillimanite and gamet, but not staurolite. The high-temperature stability limit of staurolite thus appears to lie between D7 and D12.

Sillimanite is found at scattered localities east of the sillimanite isograd, and in some thin sections appears to be replacing muscovite. However, coexisting sillimanite and K-feldspar have not 
been reported in the Paleozoic rocks. Thus, there is no definite evidence that the temperature range of muscovite has been exceeded.

Plagioclase is an important mineral in most of the rocks. The composition varies widely from almost pure albite to almost pure anorthite (ca. An 90 ) and shows little correlation with grade. Barth states that east of the biotite isograd anorthite-plagioclase is as common as oligoclase. Zoisite is rare. Hydrothermal quartz veins intersecting the schists commonly contain a little albite. The pegmatites usually contain oligoclase.

K-feldspar is absent from most of the Paleozoic rocks except those adjacent to feldspathic intrusives east of the Precambrian basement anticline. K-feldspar is also absent from pegmatites penetrating the schists. Microcline is common within the Precambrian basement rocks, usually accompanied by muscovite.

In many metamorphic terrains, chlorite is stable at grades lower than the biotite isograd, and persists into the kyanite zone. In Dutchess County, however, primary chlorite is largely restricted to a small area of quartz-garmet-chlorite phyllites just east of Clove Valley. Although a few of the biotite and staurolite metacrysts in specimen D18 are partially rimmed by a thin zone of chlorite, which may be of secondary origin and represent minor retrogradation, secondary chlorite is rare in Dutchess County.

Clove Valley and Harlem Valley are largely underlain by limestone and marble. 
The region west of the New York-Connecticut boundary is free of igneous intrusions. The region between the state boundary and the Precambrian basement contains numerous amphibolite lenses which probably represent metamorphosed gabbroic dikes and sills. The amphibolites have been folded with the schists, and the lineation and foliation within the amphibolites are concordant with those in the schists.

The locations from which rocks were collected are shown in figure 4. Petrographic descriptions of the rocks are given in appendix 1 .

\section{b. Isotopic results (Dutchess County)}

The oxygen isotopic analyses of coexisting minerals from several rocks collected from Dutchess County and vicinity are shown in figure 5 and appendix 2. (All the rocks are pelitic schists unless otherwise labelled.) The distances between the schists and veins or pegmatites represented in figure 5 are generally a few meters. Schist D51 was collected within one meter of a rock which may be classified as a pegmatitic granite or a granite-pegmatite. The rocks are arranged in order of their occurrence from west to east, which also corresponds to their order of increasing metamorphic grade. The apparent stability ranges of selected index minerals are plotted at the base of the figure.

In each mineral assemblage, the $\delta$ values invariably increase in the following sequence: magnetite - ilmenite-biotite - muscovite feldspar - quartz. 
$-59-$

FIGURE 5

Isotopic analyses of minerals in rocks from Dutchess County and vicinity. 


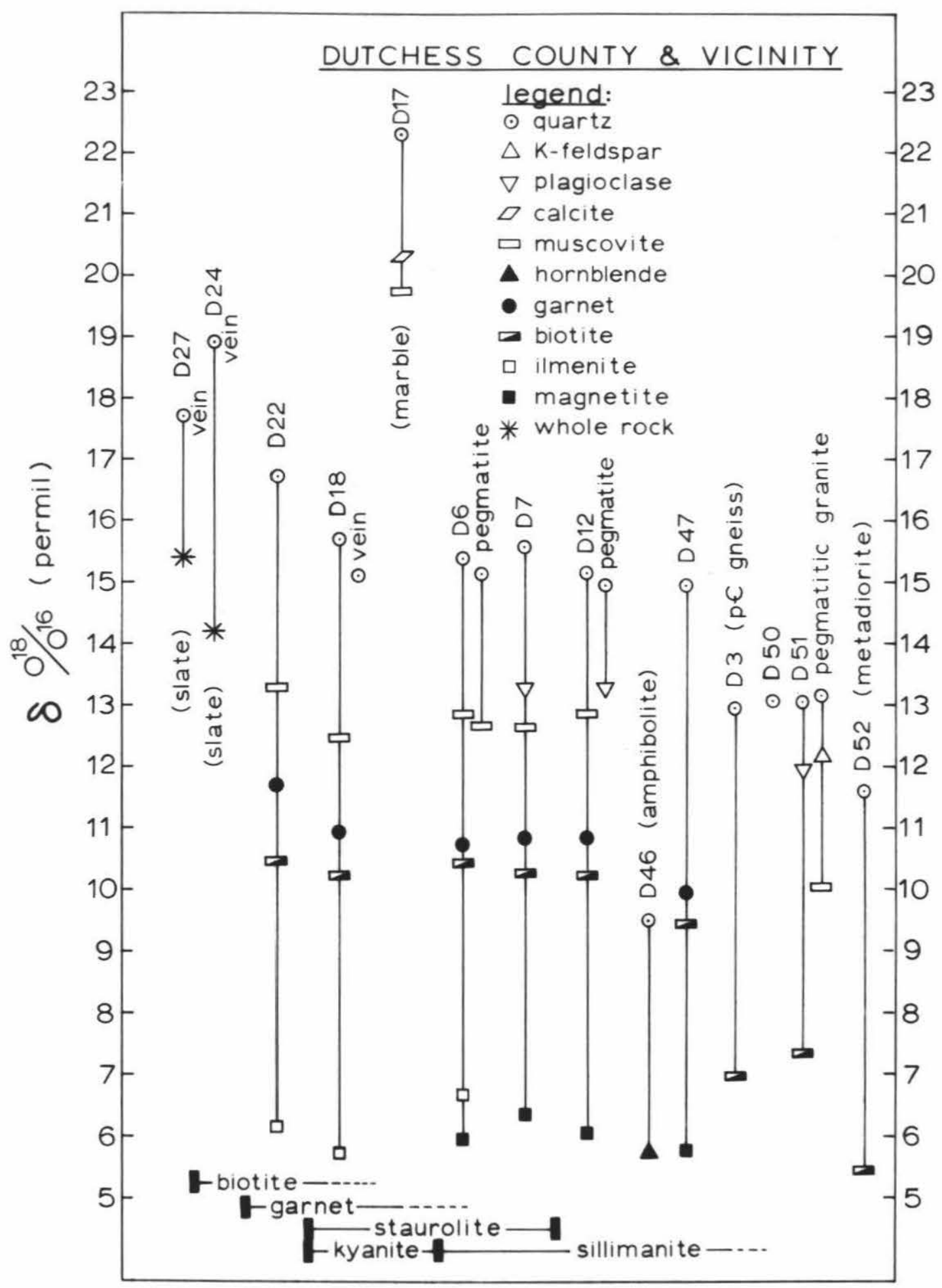

Figure 5 
Without exception, the measured quartz-magnetite, quartzilmenite, and garnet-ilmenite fractionations decrease with increasing grade. Isotopic fractionations between other mineral pairs show small varlations, but do not decrease monotonically with increasing grade. These observations are discussed in chapter 7 .

The approximate uniformity of isotopic fractionations among the coexisting minerals of these rocks suggests that conditions in Dutchess County were favorable for the attainment of isotopic equilibrium between phases and the retention of isotopic compositions during the temperature decline following metamorphism. It should be noted that appreciable mineralogical retrogradation is absent from Dutchess County rocks, unless the apparent replacement of staurolite by chloritoid near D22 can be construed as such.

The similarity of the isotopic patterns in D22 and D18 suggests that grain size is of little consequence in determining the relative isotopic compositions of minerals. The average grain sizes in D22 and D18 are roughly $0.1 \mathrm{~mm}$ and $0.7 \mathrm{~mm}$, respectively.

The $\delta$ values of most minerals in the pelitic schists, veins, and pegmatites tend to decrease with increasing grade. This is particularly true of quartz, the $\delta$ values of which range from 19 permil in the biotite zone to 13 permil in the sillimanite zone. The analyses of quartz from veins and pegmatites are similar to quartz analyses in the adjacent schists, and are plotted in figure 6. These relationships suggest that the processes determining the isotopic compositions of quartz in the veins, pegmatites, and schists were not independent. 
$-62-$

FIGURE 6

Isotopic analyses of vein-quartz, pegmatitic quartz, and whole rocks from Dutchess County and vicinity, arranged in order of increasing metamorphic grade. 
$-63-$

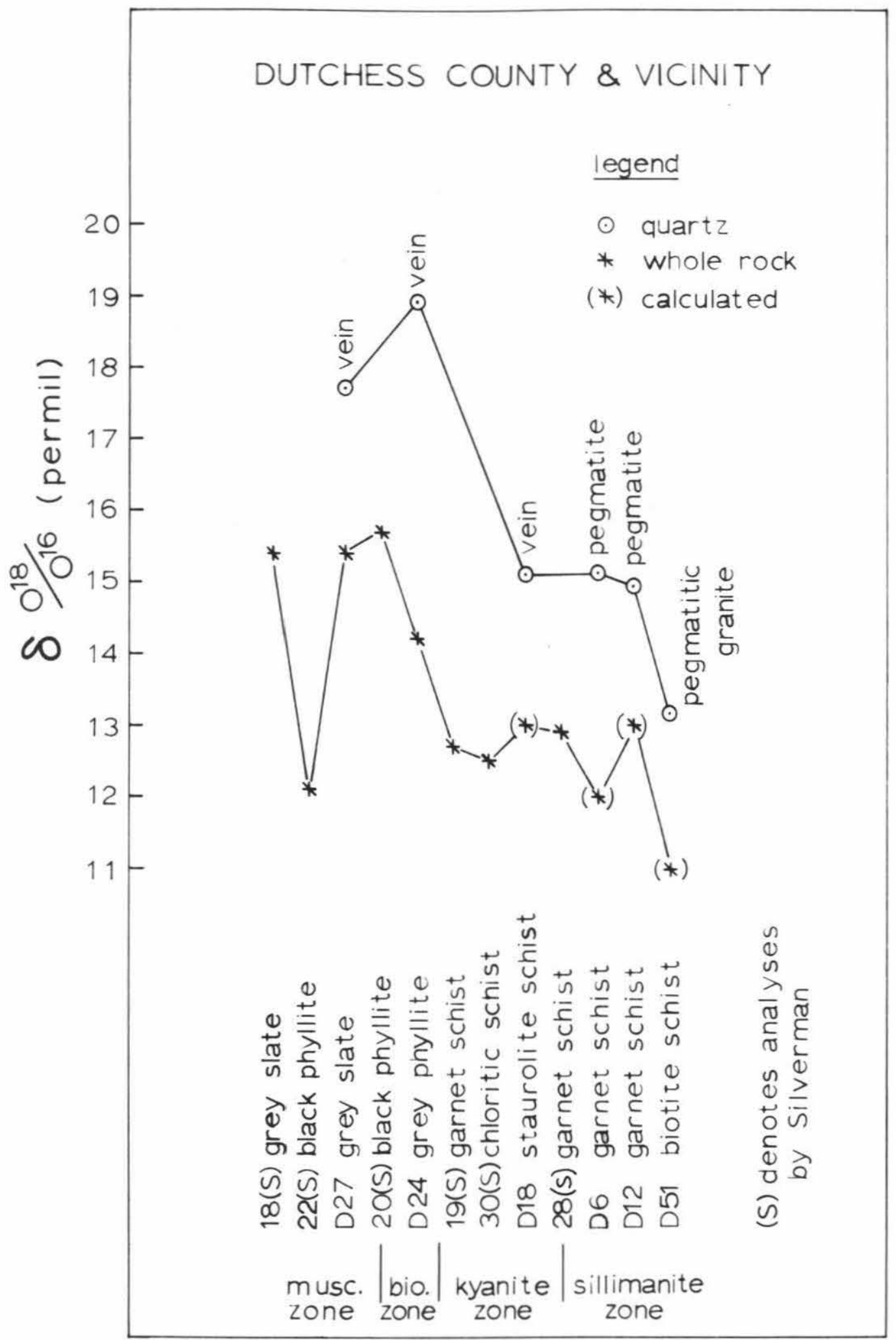

Figure 6 
The veins and pegmatites may have crystallized during the regional metamorphism from solutions in isotopic communication with the schists. It is also possible that the solutions were sufficiently copious to be isotopically insensitive to exchange with the schists, and that the variations in isotopic composition of quartz in veins and pegmatites reflect variations in temperature. If water were in equilibrium with these quartz samples at the time of crystallization, its isotopic composition could have been the same in all cases $(+11$ permil), providing temperature varied from $300^{\circ} \mathrm{C}$ to $600^{\circ} \mathrm{C}\left[0^{\prime} \mathrm{Neil}\right.$ and Clayton (60)].

The whole-rock isotopic compositions of pelitic rocks also show a general decrease in $0^{18} / 0^{16}$ values with increasing grade. The whole-rock analyses of Silverman (71) are shown in figure 6, together with the whole-rock compositions obtained from this work. This trend suggests that the metasedimentary rocks have undergone isotopic exchange with pore-fluids in communication with, or derived from plutonic rocks. This interpretation is tentative because the pre-metamorphic isotopic compositions of the rocks cannot be determined. The variations in isotopic composition are within the range expected in a sedimentary column composed of shales and greywackes [Taylor and Epstein (89)].

The similarity in isotopic composition among schists, such as D18, D6, D12, and D47, of varying chemical composition suggests that their isotopic compositions were homogenized, presumably through the mechanism of isotopic equilibration with mobile pore-fluids. Inter- 
communication was probably facilitated by fluid-bearing fissures now occupied by quartz veins and pegmatites.

One exception to the isotopic homogeneity discussed above concerns D17, a coarse-grained silicate segregation in marble. The $\delta$ value of quartz in DI7 is 7 permil larger than that of quartz in D18, a schist $1.5 \mathrm{~km}$ farther west. The quartz-muscovite fractionations in D17 and D6 are similar, suggesting that D17 is not of low-temperature post-metamorphic origin. It appears that isotopic communication between the schist and silicate segregation was not sufficient to homogenize their isotopic compositions. The extent of isotopic exchange between the marble and adjacent schists is not known. If the marble were originally a marine limestone and if the calcite in DI7 were typical of the present isotopic composition of the marble, a lowering of the $\delta$ value from +30 to +20 permil would be indicated. However, this change may have occurred before regional metamorphism, and there is no evidence of a complementary increase in the $\delta$ values of adjacent schists. It would be interesting to analyze samples taken at intervals across the marble-schist contacts.

Another rock isotopically discordant with its environment is D46, an amphibolite. The $\delta$ value of quartz in this amphibolite is typical of igneous quartz [Taylor and Epstein (75)], but 5.5 permil lower than the $\delta$ value of quartz in $D 47$, a pelitic schist one $\mathrm{km}$ to the southeast. Barth (5) cites evidence that the amphibolites represent mafic igneous rocks emplaced prior to the metamorphism. The isotopic data are compatible with an igneous origin for the amphi- 
bolites, and suggest that little isotopic exchange occurred between the meta-igneous and metasedimentary rocks. The absence of major exchange may be a consequence of low permeability in the massive amphibolites, but the problem is complex and calls for a more detailed study.

\subsection{Addison County, central Vermont}

\section{a. Metamorphic geology}

The area of interest in central Vermont extends a few kilometers to the east and west of the northernmost exposure of the Precambrian core of the Green Mountain anticlinorium. The area has been mapped and described by Cady, Albee and Murphy (11). Their map showing the metamorphic zones of the region and the locations from which rocks were taken is reproduced in figure 7 .

The Paleozoic sequence of metasediments, chiefly belonging to the Cambrian Camels Hump group, strike north-south. The grade of metamorphism increases from west to east. The Paleozoic rocks are devoid of igneous intrusions.

Rock C518 represents a fine-grained, poorly foliated, quartzitic schist from the biotite zone. C518 is the lowest-grade rock from which mineral separates were analyzed in this survey. Under the microscope all the minerals, with the exception of detrital zircon, appear to be completely recrystallized.

LA71 was collected just west of the Precambrian exposure, and represents a well-foliated muscovite-schist. The garnet isograd 
FIGURE 7

Generalized map showing the metamorphic geology and sample locations in a part of Addison County, central Vermont. [After Cady et al. (11).]

FIGURE 8

Observed mineral assemblages in the rocks from Mount Grant

(central Vermont) shown on a Thompson projection. [After Albee (1).] 


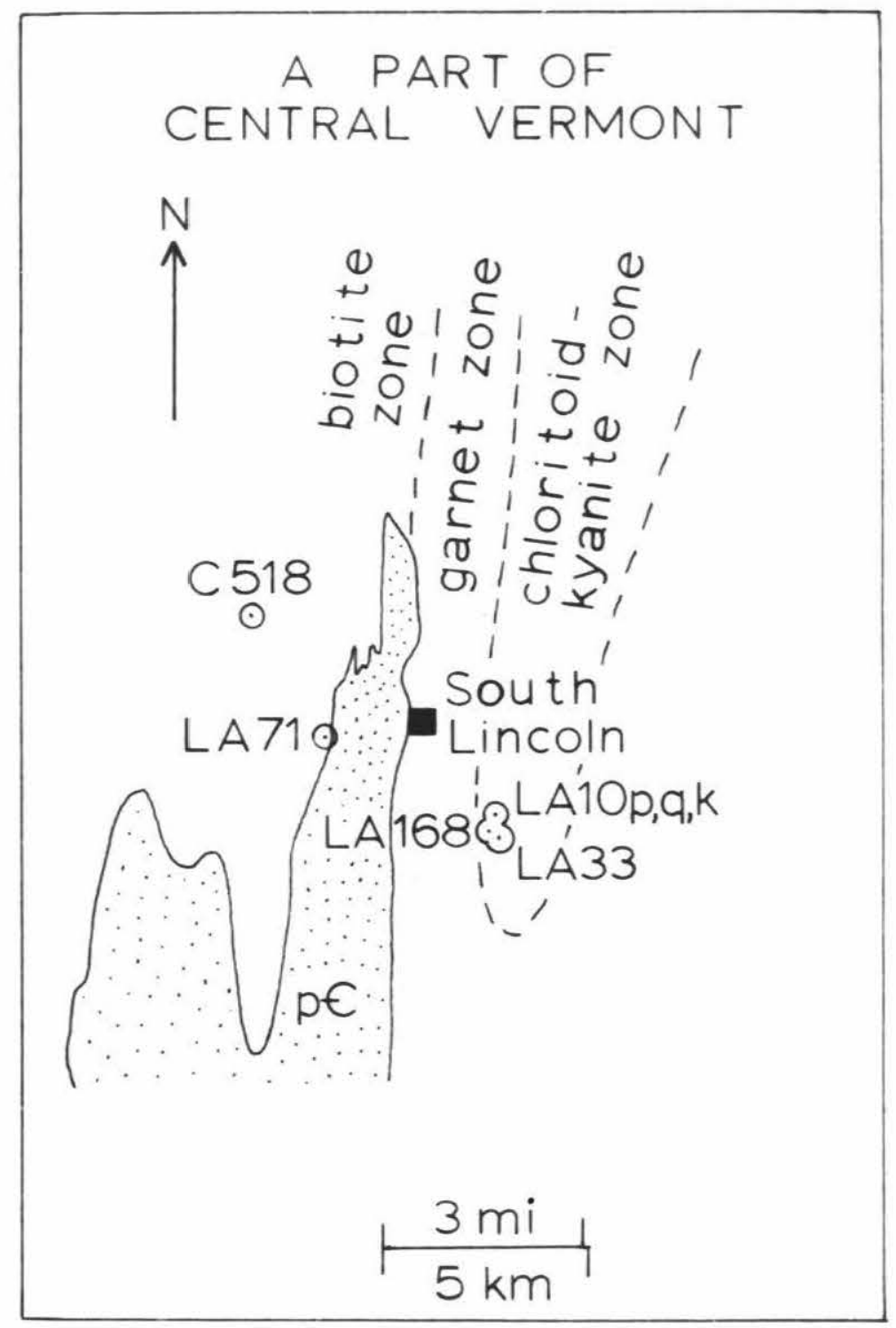

Figure 7 


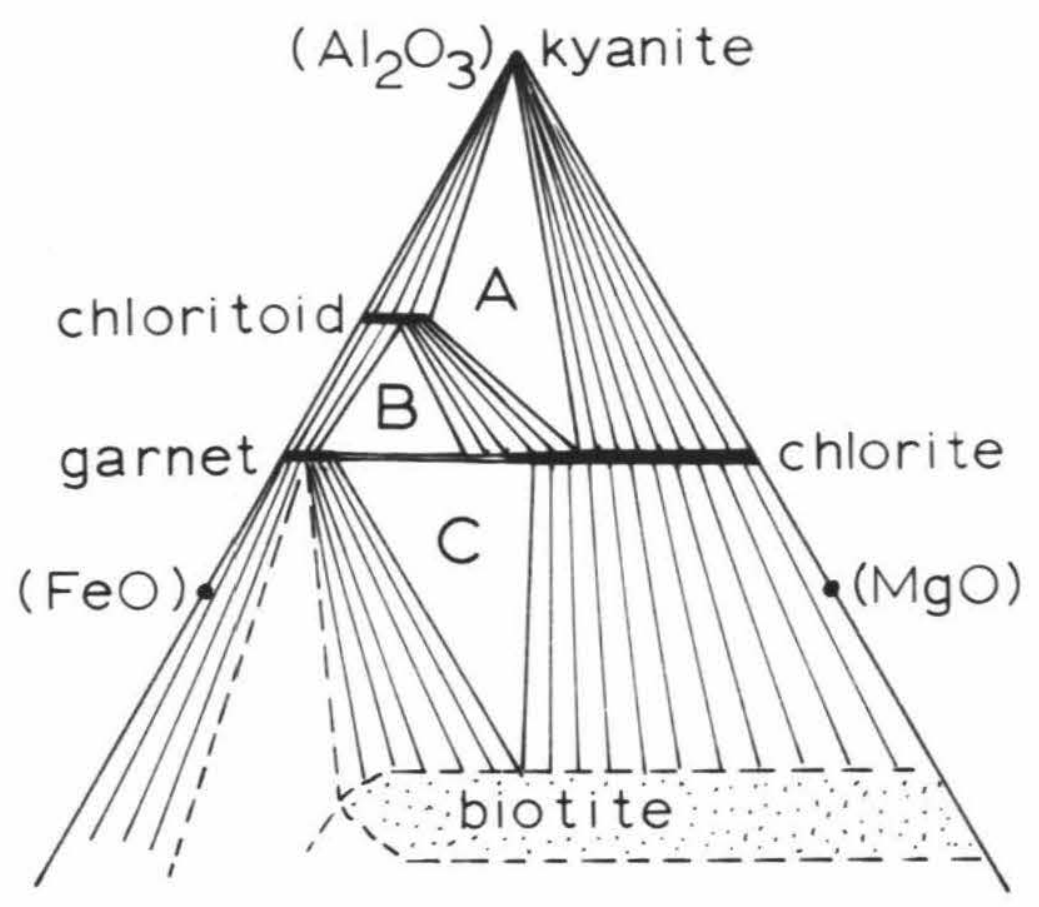
A : LA10K
$B: L A 10 p, L A 33$
C: LA10q, LA168

Figure 8 
occurs a little east of IA71 and coincides with the axis of the Green Mountain anticlinorium.

The maximum metamorphic grade in the area is represented by the chloritoid-kyanite zone approximately located between 2 and $4 \mathrm{~km}$ east of the Precambrian exposure. The occurrence of chlorite in association with kyanite is interpreted to mean that the chemical potential of water prevailing during the crystallization of these rocks was uncommonly high [Albee (1)]. Samples LAI68, IA33, LAIOp, q, and $\mathrm{k}$ were collected within a few hundred meters of one another from the chloritoid-kyanite zone near Mount Grant. The mineral assemblages in these rocks are shown on a Thompson projection in figure 8 . These rocks are assumed to be of identical metamorphic grade. The three assemblages represent compatible assemblages in rocks of different chemical composition. Minor chloritization of garnet in LAl68 is the only evidence of retrogradation observed in these rocks.

\section{b. Isotopic results (central Vermont)}

The rocks investigated from central Vermont are described in appendix 1; the isotopic analyses are presented in appendix 2 and figure 9. The isotopic analyses of minerals from rocks LAlop, $q, k$, and $t$, reported by Taylor, Albee and Epstein (76), are included.

On the basis of isotopic analyses of various minerals from rocks IAlOp, $\mathrm{q}$, and $\mathrm{k}$ of differing chemical composition, Taylor et al. concluded that isotopic equilibrium was established within each rock during metamorphism and was attained at the same temperature for all three rocks, and that oxygen-isotopic exchange occurred between all 
$-71-$

FIGURE 9

Isotopic analyses of minerals in rocks from Addison County, central Vermont. 
$-72-$

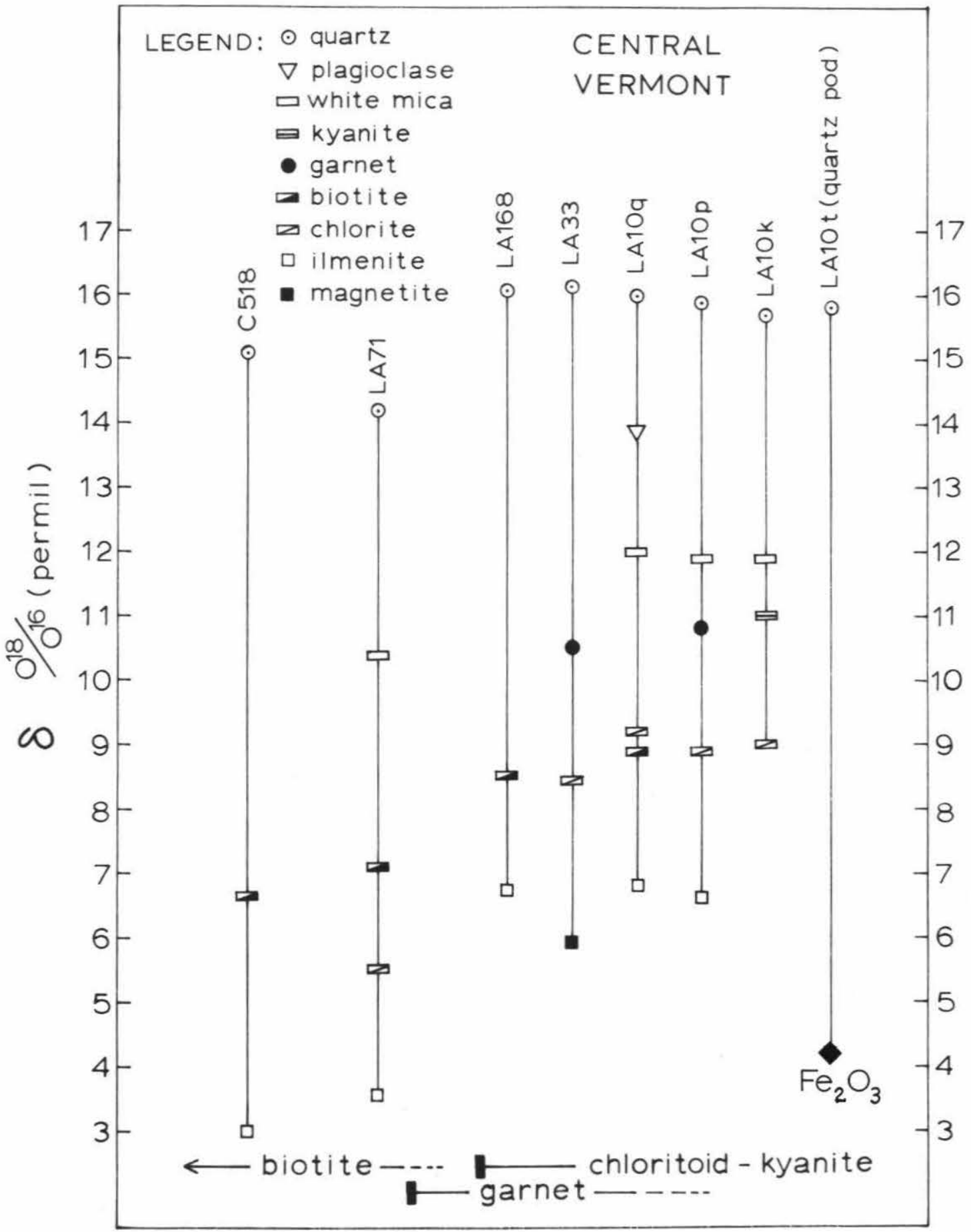

Figure 9 
three rocks. The additional analyses of minerals in IA33 and LAI68 and the analysis of garnet from IAIOp, substantiate the findings of Taylor et al. The quartz, garmet, and biotite compositions determined in LAl68 and IA33 are, within analytical precision, identical with those determined in IAIOp, $q$, and $\mathrm{k}$. Chlorite is the only mineral that has yielded appreciably different $\delta$ values in the different assemblages.

Isotopically, the magnetite in LA33 appears to be one permil lighter than ilmenite in IAI68, LAlOp and $q$. This difference probably represents the equilibrium isotopic fractionation of oxygen between magnetite and ilmenite at the temperature of formation of these rocks. (An ilmenite-magnetite fractionation of 0.7 permil was obtained in a sillimanite-grade schist from Dutchess County.)

I.Alot is a sample taken from a concordant quartz lens adjacent to IAlOk, and analyzed by Taylor et al. The quartz in the lens appears to be in isotopic equilibrium with the quartz in adjacent schists. If the hematite in the lens were also equilibrated with the schists, its isotopic composition would indicate that hematite concentrates $0^{16}$ relative to magnetite at the temperature of formation of these rocks.

The isotopic homogeneity described above does not extend to rocks several kilometers to the west. The $\delta$ values of minerals in IA71 and C518 from the biotite zone are a few permil less than those of similar minerals in rocks from the chloritoid-kyanite zone. It appears that interlithic isotopic exchange in this region was not pervasive over distances measured in kilometers. 
Quartz-ilmenite, quartz-biotite, and biotite-ilmenite fractionations decrease as one progresses from C518 through LA71 to LAl68, 33 and 10. This order corresponds to that of increasing metamorphic grade. The correlation of isotopic fractionations with metamorphic grade suggests that isotopic equilibrium was attained in coexistent quartz, biotite and ilmenite during the metamorphism, and that the records were fairly well preserved during the temperature decline following metamorphism.

The isotopic behavior of chlorite is irregular. Chlorite in LA71 is 1.6 permil lighter than coexistent biotite, whereas chlorite and biotite appear to have similar isotopic compositions in the Mount Grant rocks. In neither case is there definite petrographic evidence that the chlorite is secondary in origin. The isotopic records in chlorite may be more sensitive than those in quartz, biotite, and ilmenite to the post-metamorphic histories of the rocks.

\subsection{Southern Vermont}

\section{a. Metamorphic geology}

The geology of southerm Vermont has been described by Thompson (80). The map in figure 10 is reproduced from that compiled by Doll

et al. (22), and shows the metamorphism and Precambrian exposures of the area. The locations from which the analyzed rocks were collected are also shown in the figure.

The Chester and Athens gneiss domes east of the Green Mountain anticlinorium are mantled by metamorphic strata of early Paleozoic age. The Paleozolc rocks are intensively deformed as a result of the doming. 
FIGURE 10

Map showing the metamorphic geology and sample locations in central and southern Vermont. [After Doll et al. (22).] 
CENTRAL AND $\stackrel{-76-}{ }$ SOUTHERN VERMONT

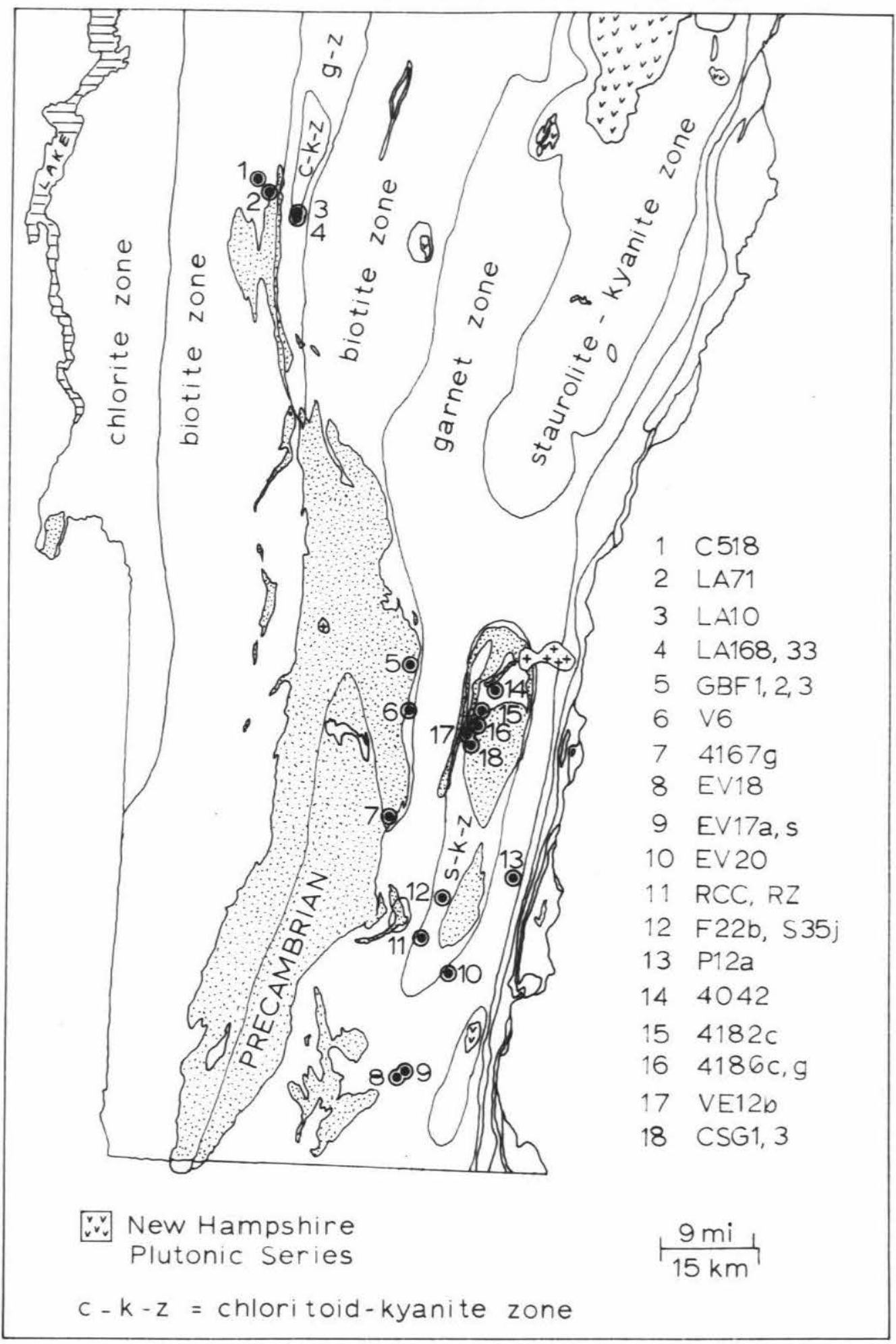


The rocks exposed in the anticlinorium and domes are predominantly Precambrian gneisses but include schists and marbles of the Cavendish Formation, which is possibly early-Cambrian in age.

The zones of regional metamorphism are roughly concentric about the domes, with the highest grades (staurolite-kyanite) attained near the centers. Garnet porphyroblasts containing spirally-arranged inclusions indicate the deformation and metamorphism to be essentially contemporaneous. Farther south, metamorphic grade increases towards a granitic body of the New Hampsire plutonic series, which was probably emplaced during the metamorphism. The metamorphism is considered to be Devonian in age.

A few mafic and ultramafic intrusions have been metamorphosed within the Paleozoic strata. The only plutonic rocks that postdate the metamorphism are small alkalic stocks, the largest of which is the Ascutney complex in the northeasterm part of the Chester dome.

Rocks GBF1, GBF2, and GBF3 represent a pegmatite, a quartz-lens in schist, and a quartzite, respectively, collected within a few meters of one another from the Green Mountain Precambrian exposure. The quartzite was probably metamorphosed to the sillimanite grade before the Cambrian, and later subjected to a lower-grade Paleozoic metamorphism of biotite grade.

V6 is a quartz-mica-schist collected from the Tyson formation in the biotite zone near the garnet isograd.

$4167 g$ is a Precambrian gneiss from the Green Mountains. The presence of chlorite and unchloritized euhedral garnet in $4167 \mathrm{~g}$ suggests 
that this rock was metamorphosed to the garmet grade. In that case, the garnet isograd as mapped is about $1 \mathrm{~km}$. in error at this locality. EV18, EV17s, and EV2O are mica schists collected south of the Athens dome in the garmet zone. The garmets in these rocks are largely replaced by chlorite. EVI8 contains abundant sodic plagioclase. EVI7a is a chlorite--and epidote--bearing amphibolite collected within a few meters of EVI7s.

$\mathrm{P} 12 \mathrm{a}$ is a "rolled" garnet porphyroblast collected from the calcareous Waits River formation in the garnet zone east of the Athens dome.

RZ is a pelitic schist from the staurolite-kyanite zone just west of the Athens dome. It contains slightly-chloritized gamet porphyroblasts a few centimeters in diameter. RCC is a finely laminated calcite-bearing amphibolite collected within a few meters of RZ.

F22b and $S 35 j$ represent adjacent garnet- and staurolite-bearing schists near the westerm edge of the Athens dome. F22b also contains kyanite. Garnets are unchloritized.

VEI2b is a sample of Gassetts schist (Cavendish formation) from the western edge of the Chester dome. Garnets are partially rimmed by chlorite. $4182 \mathrm{c}$ and 4042 represent the Cavendish formation north of $V E I 2 b$. $4186 \mathrm{c}$ is a xenolith of Cavendish formation found in a small stock of trondjemite (4186g) located in the gneiss-core of the Chester dome.

CSGI and CSG3 are samples of the Reading gneiss and a granitic dyke, respectively, located in the core of the Chester dome. 
Petrographic descriptions of the above rocks are given in appendix 1 .

\section{b. Isotopic results (southern Vermont)}

Isotopic analyses of minerals from the rocks described above are shown in figure 11. The rocks were collected from a region $60 \mathrm{~km}$ long and $20 \mathrm{~km}$ wide. A large variety of rock types and metamorphic grades are represented. Therefore, it is not surprising that simple correlations between the $\delta$ values and metamorphic grade are not observed.

One prominent feature of the results is the unusually low $\delta$ values in the 3 schists (EVI8, EVI7s, and EV2O) from the garmet zone south of the Athens dome. The $\delta$ values of these rocks are similar to those of igneous rocks, and suggest that they have undergone isotopic exchange with isotopically light pore fluids possibly in communication with, or derived from, plutonic or igneous rocks. It is interesting to note that the only synmetamorphic granite in southern Vermont also occurs in the region south of the Athens dome. EV18, EVI7s, and EV20 contain garnets which have been extensively chloritized, but the low $\delta$ values and retrogradation need not be genetically related.

The $\delta$ values in $\mathrm{P} 12 \mathrm{a}$ are slightly larger than those typical of other schists analyzed. This may be a consequence of the presence of calcite in $\mathrm{P} 12 \mathrm{a}$.

The isotopic compositions of minerals in F22b are, within analytical precision, the same as those of similar minerals in $535 \mathrm{j}$, an adjacent rock. This homogeneity is presumably a consequence of 
FIGURE 11

Isotopic analyses of minerals in rocks from southern Vermont.

Legend:

$\odot \quad$ quartz

$\square$ muscovite

$\Delta$ hormblende

- garnet

biotite

$\square$ chlorite

ㅁ ilmenite

- magnetite

- hematite 
- 81 -

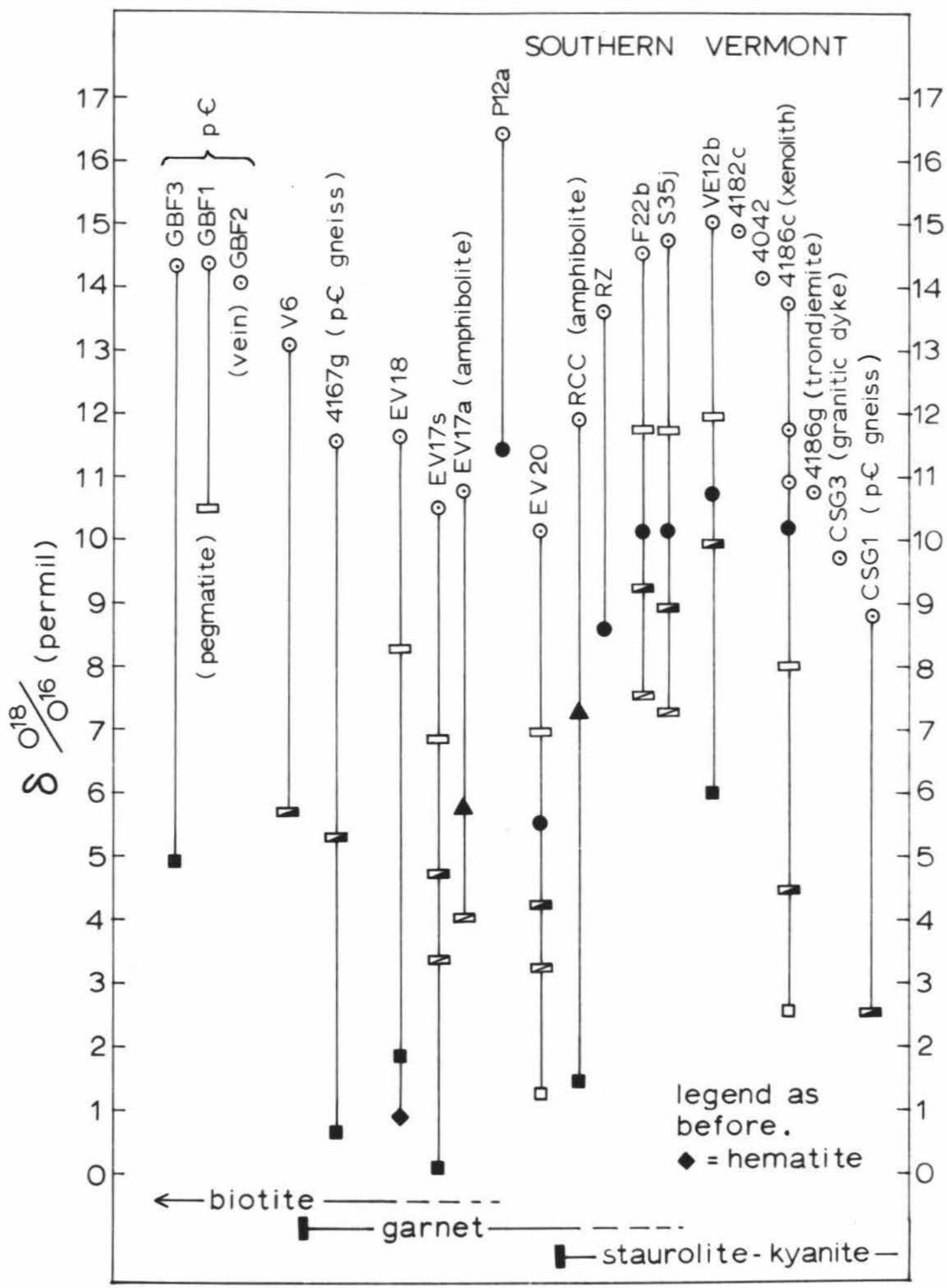

Figure 11 
isotopic communication between the two schists during metamorphism, because their chemical compositions are not equivalent. Another example of isotopic homogeneity is found in GBFI, 2 and 3, a pegmatite, quartz vein, and adjacent Precambrian quartzite. The isotopic compositions of quartz in these rocks are identical within analytical precision. Isotopic equilibrium between the quartz in metasedimentary rocks and adjacent veins or pegmatites was also found in Dutchess County.

Of the two amphibolites analyzed, EVI7a appears to be in approximate isotopic equilibrium with an adjacent schist (EVI7s), whereas the $\delta$ of quartz in RCC is nearly 2 permil smaller than that of quartz in an adjacent schist ( $R Z)$. The $\delta$ values of quartz in igneous rocks are commonly about +10 permil [Taylor \& Epstein (75)], so the $\delta$ values of quartz in EVI7a and RCC are roughly 1 and 2 permil larger than those expected in igneous rocks. Of course, their whole-rock isotopic compositions may be similar to those of typical mafic igneous rocks. The isotopic composition of the Reading gneiss in the Chester dome is similar to that of igneous rocks, but this should not be constmued as evidence that the Reading gneiss is an ortho-gneiss. Extreme or repeated metamorphism may homogenize the isotopic compositions of metasedimentary and igneous rocks.

Isotopic fractionations among the coexisting minerals of these rocks exhibit certain consistencies which are discussed in chapter 7. Isotopic fractionations which appear to be incongruous with metamorphic grade include: 
1. The quartz-magnetite fractionation in GBF3, a Precambrian quartzite with a complex metamorphic history;

2. The quartz-biotite fractionation in CSGI, a gneiss in the core of the Chester dome;

3. The fractionations in 4186c, a xenolith.

The anomalous $\delta$ values of minerals in the xenolith--4186care evidently a consequence of isotopic exchange between the xenolith and the trondjemite--4186g. The xenolith is believed to have originated from the Cavendish formation, and its minerals probably had isotopic compositions similar to those in VEl2b. A detailed discussion of this case is given in section 6.3 .

It is clear that this preliminary survey of the isotopic behavior of oxygen in the metamorphic rocks of southern Vermont exposes more problems than it solves. However, the data do suggest which mineral assemblages achieved isotopic equilibrium, and which rocks experienced isotopic exchange with their environments. This information bears upon the crystallization histories of the mineral assemblages, and may be of significance in determining the extent to which the rocks were "open" to mobile components during metamorphism.

\subsection{Central Connecticut}

a. Metamorphic geology

The area of interest in Connecticut follows the gneiss-dome terrain from the Massachusetts border to the mouth of the Connecticut River. The metamorphic petrology of the southern region has recently 
been described by Lundgren $(54,55)$, but the metamorphism of the northern region is not well documented. Figure 12 is a geological map of central Connecticut compiled from those of Rodgers et al. (63), Rosenfeld and Eaton (65), and Lundgren (55).

The grade of metamorphism generally increases towards the axes of the anticlines and towards the gneiss-domes but also shows a progressive increase towards the south. The kyanite and sillimanite isograds are usually gradational. Fine-grained sillimanite is often found in the transition zones as pseudomorphs after kyanite porphyroblasts.

Rock A66a was collected from the Clough quartzite in the Bolton syncline, from an area in which staurolite has been reported by Collins (17). Rock A57d was collected from the same horizon some $30 \mathrm{~km}$. farther south. Rosenfeld and Eaton report the presence of staurolite and kyanite in adjacent rocks. No isograds can be located between A66a and A57a on the basis of published information.

A56 $\mathrm{j}$ is a sample of schist from the Brimfield formation just north of the Haddam gneiss-dome, and contains both sillimanite and staurolite. Al5h4 is an amphibolite occurring a few hundred meters northeast of $\mathrm{A} 56 \mathrm{j}$. Kyanite-bearing rocks are mapped by Rosenfeld and Eaton about $1 \mathrm{~km}$. to the west of $\mathrm{A} 56 \mathrm{j}$ and $\mathrm{Al} 15 \mathrm{~h} 4$.

In the vicinity of the mouth of the Connecticut River, Lundgren has located an isograd representing the decomposition of muscovite, in the presence of quartz, to sillimanite and orthoclase. Rock A64g was collected from the Brimfield formation within the sillimanite-orthoclase zone. The presence of migmatites in the area of A64g suggests 
a. Map showing the metamorphic geology and sample locations in central Connecticut. [After Rodgers et al. (63), Rosenfeld and Eaton (65), and Lundgren (55).]

b. Isotopic analyses of minerals in rocks from central Connecticut. 


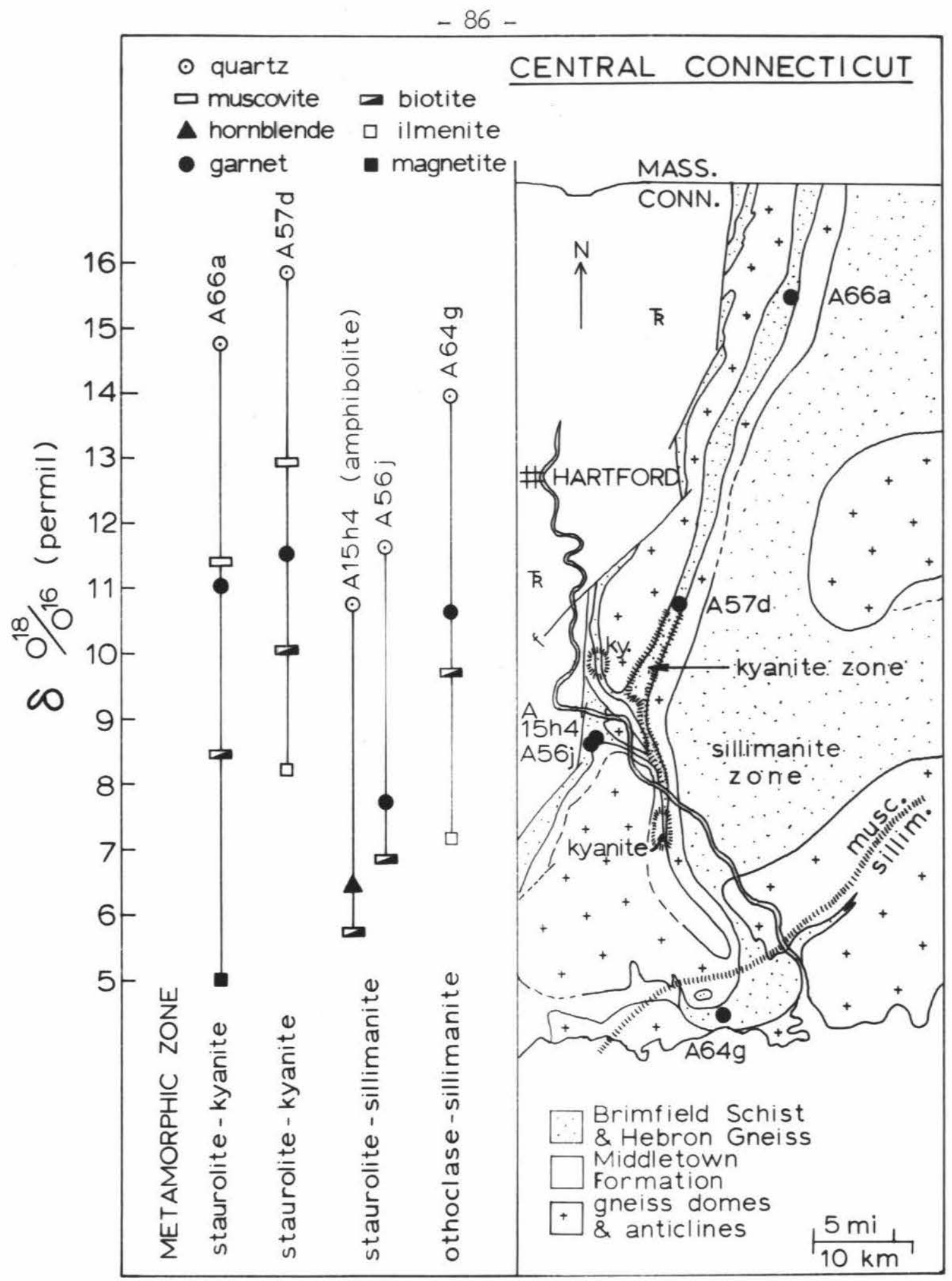


that the temperature was close to that required for the incipient fusion of the gneisses. Pegmatites are abundant in the neighborhood of $\mathrm{A} 64 \mathrm{~g}$.

\section{b. Isotopic results (central connecticut)}

The isotopic analyses of minerals from the 5 rocks collected in central Connecticut are shown in figure 12 .

The $\delta$ values of quartz from the quartzites are several permil larger than those typical of igneous quartz, though not unlike those of metamorphosed pelitic rocks. This may mean that the precursor sandstones were not derived from source areas dominated by igneous rocks, but there are too many variables to allow a definite interpretation.

The $\delta$ value of quartz in the amphibolite (AI5h4) is approximately one permil smaller than that of quartz in a nearby schist (A56j), and about one permil larger than that typical of igneous quartz. However, the whole-rock isotopic compositions of $\mathrm{Al} 5 \mathrm{~h} 4$ and mafic igneous rocks may be similar.

Although A64g represents the highest metamorphic grade investigated, and was collected from an area of abundant pegmatites, the isotopic composition of this schist is typical of other pelitic schists analyzed. See figure 22.

Quartz-biotite fractionations have been determined in all 5 rocks, and decrease monotonically with increasing metamorphic grade. Quartz-garnet fractionations show little variation, and do not vary systematically with grade. 
The quartz-biotite fractionations are similar in Al5h4 and A56j. The hornblende-biotite fractionation in Al5h 4 is similar to the garnet-biotite fractionation in $A 56 j$. These observations suggest that garnet and hormblende do not fractionate the isotopes of oxygen with respect to one another under the conditions of formation of these rocks.

\subsection{Northern Idaho}

a. Metamorphic geology

The metamorphism of the Belt series northwest of the Idaho batholith, in Shoshone and Clearwater counties, has been described in a. number of papers by Hietanen $(37,38,39,40)$, and the following summary is based on these publications.

The Belt series metasediments of Precambrian age consist of interbedded pelitic schists, quartzites, granofelses, and diopside- or biotite-bearing gneisses. Folding and metamorphism took place during the Nevadan orogeny in the Jurassic, and was followed by the intrusion of the Idaho batholith during the early Cretaceous. The intensity of folding increases toward the southwest in the area shown in figure 13. The metamorphism increases from north to south, from chlorite to sillimanite grade, in a distance of about $50 \mathrm{~km}$. The biotite, garnet, staurolite-kyanite, and sillimanite isograds are shown in the figure.

Coexisting kyanite, andalusite, and sillimanite are found in cordierite-bearing mica schists in the central regions of the map, adjacent to anorthosite bodies. Hietanen reports petrographic evidence that the following inversions took place: 1) sillimanite to 
FIGURE 13

Map showing the metamorphic geology and sample locations in parts of Cle arwater and Shoshone Counties, northern Idaho. [After Hietanen (39).] 
$-90-$

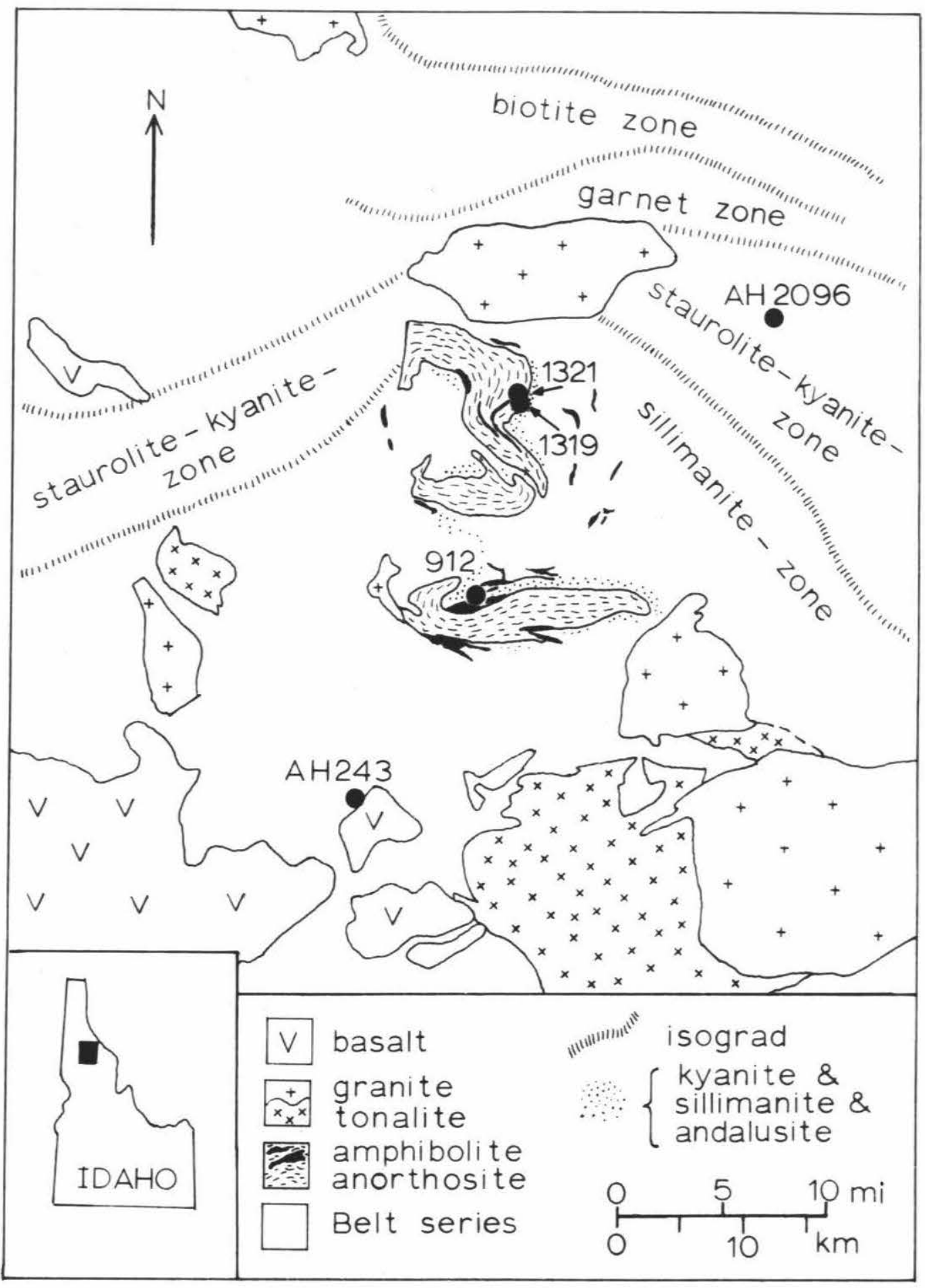


kyanite, 2) sillimanite to andalusite, 3) kyanite to andalusite, 4) kyanite to sillimanite, 5) andalusite to sillimanite. These observations suggest that the rocks crystallized close to the triple point of the polymorphic aluminum silicate, $\mathrm{Al}_{2} \mathrm{SiO}_{5}$.

The bodies of anorthosite are roughly concordant, and have gradational contacts with the schists. The anorthosite is composed of small grains of bytownite and later, larger grains of andesine. Neither plagioclase is zoned. Hietanen considers the anorthosite to be a metasomatized shaley limestone, in which bytownite crystallized during the regional metamorphism and andesine formed later as a result of the introduction of sodium.

Small bodies of garmet amphibolite occur in the schist near the anorthosite masses and some are included in the anorthosite. Farther south, along the northwestem contact zone of the batholith, Hietanen reports evidence that $\mathrm{Ca}, \mathrm{Fe}, \mathrm{Mg}$, and locally $\mathrm{Na}$, have been introduced, and that $\mathrm{K}$ and $\mathrm{Si}$ have been removed. K-feldspar is very scarce in the basified aureole, which is about $15 \mathrm{~km}$ wide, and also in a zone about $10 \mathrm{~km}$ wide, outside it.

The locations from which 5 rocks were collected are shown in figure 13. AH2096 and AH243 are pelitic schists. 1321 is a garnetbearing amphibolite. 1319 contains garmet, quartz, kyanite, chlorite, and plagioclase, and occurs as an inclusion, with dimensions of a few meters, in anorthosite. 912a is a quartz-plagioclase-mica schist containing kyanite, sillimanite, and magnesium-rich biotite. The rocks are described in more detail in appendix 1. 


\section{b. Isotopic results (northern Idaho)}

The isotopic analyses of minerals in 5 rocks from northern Idaho are shown in figure 14.

The whole-rock isotopic compositions of AH2096 and AH243 are similar to those of other analyzed pelitic schists. Quartz-ilmenite and biotite-ilmenite fractionations are smaller in AH243 (sillimanite grade) than in AH2096 (kyanite grade), but the quartz-biotite fractionations are approximately the same in both rocks.

The remaining 3 rocks were collected from an unusual setting in which kyanite, andalusite, and sillimanite coexist in schists adjacent to anorthosites. The $\delta$ values of quartz in 1319 and $912 a$, which are considered to be metasedimentary rocks, are several permil smaller than those typical of quartz in pelitic schists, and are even slightly smaller than those typical of igneous quartz. The implication is that 1319 and 912 a experienced considerable isotopic exchange with environments impoverished in $0^{18}$ relative to those previously encountered in metamorphic rocks. Since 1319 represents a lens of schist enclosed in anorthosite, the $\delta$ (quartz) value of +8.7 permil in this schist suggests that the $0^{18} / 0^{16}$ ratios of minerals in the anorthosite are no greater than those commonly found in igneous minerals.

1321 is a garnet amphibolite located in anorthosite near 1319. The $\delta$ value of quartz in the amphibolite is +9.2 . This value is compatible with an igneous ancestry for the amphibolite, but other origins are not excluded. 
$-93-$

FIGURE 14

Isotopic analyses of minerals in rocks from northern Idaho. 
- $94-$

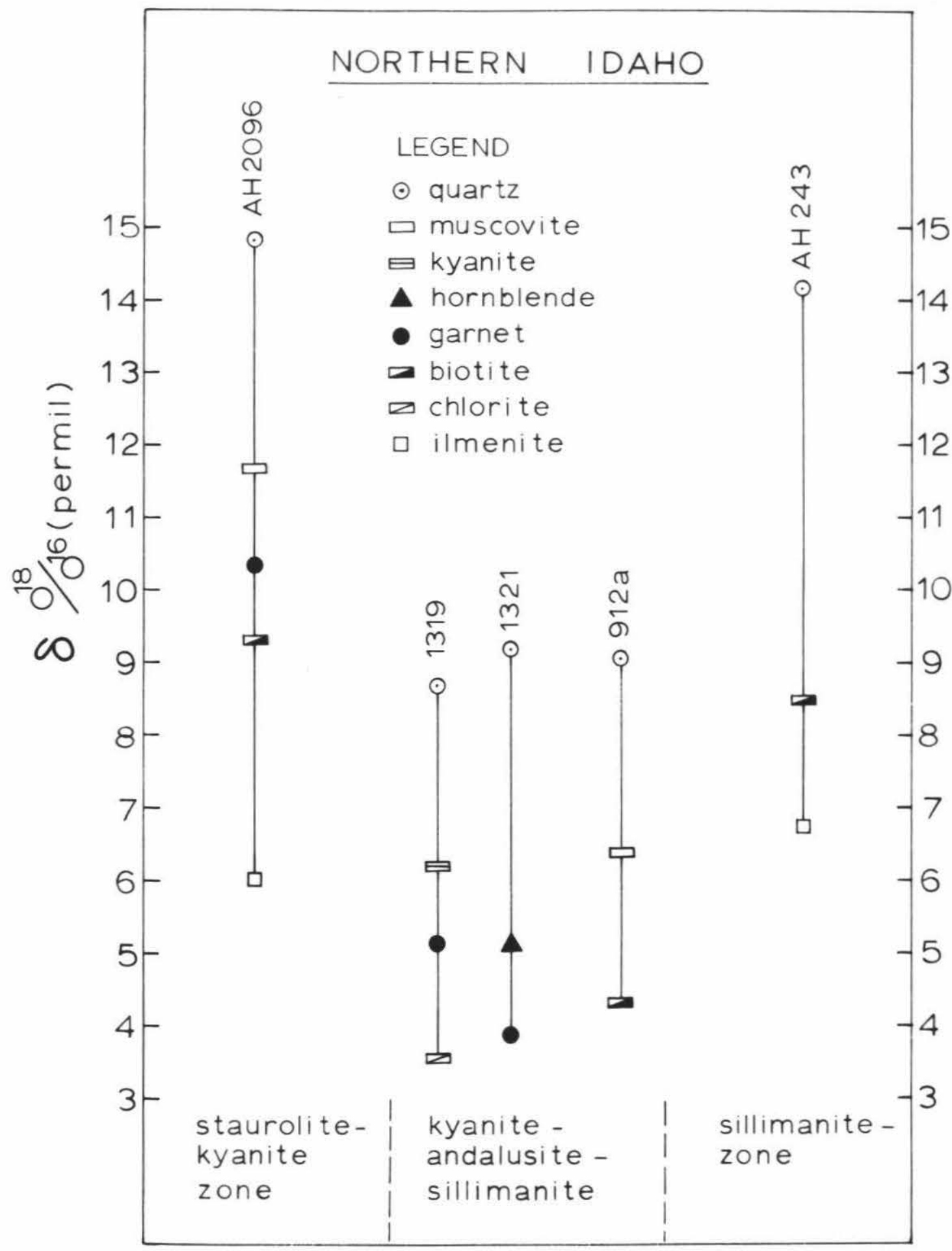

Figure 14 
The isotopic fractionations among the coexisting minerals of 1319, 1321, and 912a are rather chaotic. For example, the quartzgarnet fractionations in 1319 and the nearby amphibolite, 1321, are 3.6 and 5.3 permil, respectively. Geological evidence suggests that these rocks have had complex metamorphic histories, probably involving metasomatism [Hietanen (37)]. A $9 \mathrm{~cm}$ porphyroblast of garnet from 1319 was analyzed with the purpose of investigating the possibility that isotopic effects of its complex history were preserved in the form of isotopic zoning. However, isotopic zoning in the garmet was found to be negligible. The results are described in more detail in section $6.3 \mathrm{c}$. 
CHAPTER VI

\section{GENERAL DISCUSSION OF RESULTS}

\subsection{Relative $0^{18} / 0^{16}$ ratios in coexisting minerals}

On the basis of the analyses presented in Chapter V, it is possible to list the minerals in order of their relative tendency to concentrate $0^{18}$ in metamorphic rocks:

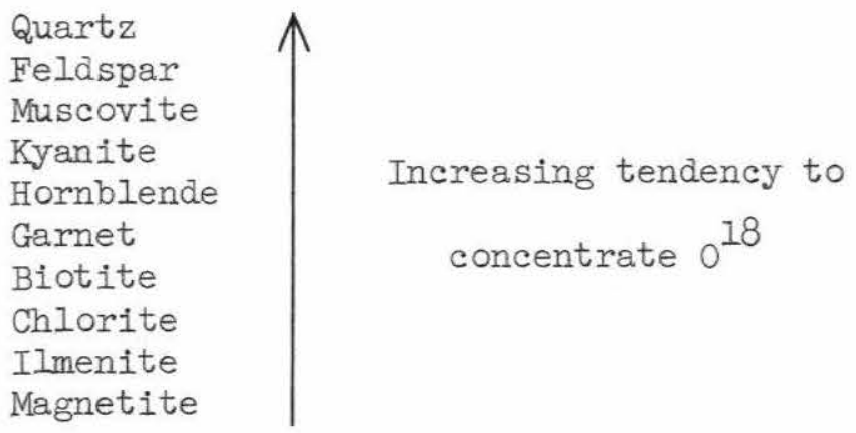

This sequence is identical with that reported by Taylor et al. (76) except that garnet and magnetite have been added and the relative positions of chlorite and biotite have been changed. Since kyanite and hormblende were not analyzed in the same assemblage, the relative positions of these two minerals in the above list are not definitely established. Euhedral hematite was analyzed in one rock (EVI8) and found to be about 0.5 permil lighter than coexisting subhedral magnetite, but James and Clayton (44) have found that hematite is commonly enriched in $0^{18}$ relative to coexistent magnetite in the iron formations near Lake Superior. 
Although about 5 minerals in each of 20 metamorphic rocks were analyzed, only one rock was found to contain a set of minerals which did not follow the sequence listed above. The anomalous rock is a xenolith of schist occurring in a trondjemite stock. The xenolith has obviously undergone partial isotopic exchange with the trondjemite.

The prevalence of the above sequence in metamorphic rocks leads one to assume that it is the sequence of isotopic compositions obtained at equilibrium.

An interesting empirical elucidation of this sequence is that of Taylor and Epstein (75). Noting a correlation between the predominant type of bonding in minerals and their isotopic compositions in igneous rocks, Taylor and Epstein assumed the following equilibrium relations at igneous temperatures:

$\begin{array}{cc}\text { Bond Type } & \text { Relative } \delta \\ \text { Si-O-Si } & 10 \\ \text { Si-O-AI } & 8 \\ \text { Si-O-M } & 6\end{array}$

The $\mathrm{M}$ denotes $\mathrm{Mg}$, $\mathrm{Fe}$ or Ca.

On the basis of kyanite and magnetite analyses reported in this work, it is suggested that this list be expanded as follows: 


$\begin{array}{lcc}\text { Bond Type } & \text { Relative } & \text { B-Parameter } \\ \text { Si-O-Si } & 10 & 1.0 \\ \text { Si-O-AI } & 8 & 0.7 \\ \text { Al-O-AI } & 6 & 0.4 \\ \text { Si-O-M } & 6 & 0.4 \\ \text { M-O-M } & 3 & 0.0\end{array}$

The $\beta$-parameter, defined by

$$
\beta(\text { mineral } A)=\frac{\text { In } \alpha_{\text {Magnetite }}^{\mathrm{A}}}{\ln q_{\text {Magnetite }}^{\text {Quartz }}} \approx \frac{\triangle_{\text {Magnetite }}^{\mathrm{A}}}{\Delta_{\text {Magnetite }}^{\text {Quartz }}}
$$

has the advantage over the relative $\delta$-notation of readily permitting comparisons between assemblages having crystallized at different temperatures. The temperature dependence of $\beta$-parameters in metamorphic rocks is discussed in section 7.6 ; there is no evidence in the present data to indicate marked variations with temperature.

From the $\beta$-parameters assumed for the various bond types, $\beta$ parameters can be calculated for certain coexisting igneous and metamorphic minerals as shown in table 8 .

The $\beta$-parameters calculated for hypothetical anhydrous biotite and hornblende are decidedly higher than the $\beta$-parameters derived from isotopic analyses of naturally occurring biotite and hornblende. The difference suggests that the isotopic composition of oxygen in the hydroxyl groups is lighter than that of oxygen in the other lattice sites. 


\section{TABIE 8}

Model for the prediction of equilibrium $\beta$-parameters in igneous and metamorphic rocks

\begin{tabular}{|c|c|c|c|c|c|c|}
\hline Mineral & $\begin{array}{r}\text { Per } \\
\text { Si-0-Si }\end{array}$ & $\begin{array}{l}\text { ent of Bo } \\
\text { Si-O-AI }\end{array}$ & $\begin{array}{l}\text { d Type in } \\
\text { AI-O-AI }\end{array}$ & $\begin{array}{c}\text { Structure } \\
\text { Si-0-M }\end{array}$ & $\mathrm{M}-\mathrm{O}-\mathrm{M}$ & $\begin{array}{c}\beta_{-} \\
\text {Parameter }\end{array}$ \\
\hline Quartz & $\underline{100}$ & 0 & 0 & 0 & 0 & 1.00 \\
\hline K-Feldspar & 50 & 50 & 0 & 0 & 0 & 0.85 \\
\hline Albite & 50 & 50 & 0 & 0 & 0 & 0.85 \\
\hline Labradorite & 25 & 75 & 0 & 0 & 0 & 0.78 \\
\hline Anorthite & 0 & 100 & 0 & 0 & 0 & 0.70 \\
\hline Biot. (Anh.) & 30 & 30 & 0 & 40 & 0 & $(0.67)$ \\
\hline Hormb. (Anh.) & 45.5 & 0 & 0 & 54.5 & 0 & $(0.67)$ \\
\hline Kyanite & 0 & 66.7 & 33.3 & 0 & 0 & 0.60 \\
\hline Pyroxene & 33.3 & 0 & 0 & 66.7 & 0 & 0.60 \\
\hline Garnet & 0 & 40 & 0 & 60 & 0 & 0.52 \\
\hline Corundum & 0 & 0 & 100 & 0 & 0 & 0.40 \\
\hline Olivine & 0 & 0 & 0 & 100 & 0 & 0.40 \\
\hline Magnetite & 0 & 0 & 0 & 0 & 100 & 0.00 \\
\hline
\end{tabular}


Whether or not this type of compilation proves useful in predicting isotopic fractionations remains to be seen. The agreement between the predicted value of 0.52 for the $\beta$-parameter of garnet and the average measured value of 0.53 (see figure 30) is encouraging. Naturally-occurring corundum has not yet been analyzed, and may provide one test of the method. It is predicted to have a $\beta$-parameter of 0.4 .

\subsection{Isotopic fractionations related to chemistry}

a. Diffusion and recrystallization

Since the diffusion of oxygen in the solid state is an exceedingly slow process (see section 2.6), the establishment of isotopic equilibrium in a mineral assemblage is probably dependent upon the simultaneous crystallization or recrystallization of the constituent minerals. The recrystallization of an assemblage should also lead to "mineralogical" equilibrium. Thus, if mineralogical equilibrium were not achieved, isotopic equilibrium would not be expected. However, it is possible that minerals could crystallize in an environment which readily permits the exchange of oxygen but not some other critical component. It is also conceivable that metastable minerals could crystallize in isotopic equilibrium with their environments. For example, the oxygen-isotopic compositions of both calcite and its metastable polymorph--aragonite--have been successfully used in paleotemperature studies, suggesting that aragonite can equilibrate isotopically with water.

Because the largely-covalent $\mathrm{SI}-0$ and $\mathrm{Al}-0$ bonds are the strongest bonds in silicates, the coefficients of diffusion of oxygen 
in silicates are likely to be smaller than those of the common cations. We may thus expect that once equilibrium has been obtained, the isotopic partition of oxygen will be less amenable to later reorganization than the partition of cations. The observations of Lowenstam (53) afford an example of the relative permanence of cationic and isotopic records in carbonates. From a comparison of $\mathrm{Mg} / \mathrm{Ca}$ and $0^{18} / 0^{16}$ ratios in the calcite shells of recent and fossil brachiopods, Lowenstam concluded that the cation ratios are usually altered during diagenesis, whereas the oxygen-isotope ratios in the same shells are usual1y preserved.

The above considerations are pertinent to the use of oxygenisotopes in determining whether a rock represents an equilibrium mineral assemblage and whether recrystallization has taken place. However, these guides may not be of general validity, and each case should be treated individually.

\section{b. Isotopic and chemical compositions of biotite}

Factors other than temperature and pressure which may influence the equilibrium isotopic fractionation of oxygen between minerals include :

1) The chemical compositions of members of isomorphous chemical series such as garnet, muscovite, biotite, hornblende, and chlorite;

2) The substitution of fluorine for hydroxyl groups in hydrous minerals such as muscovite, biotite, hormblende, and chlorite. 
An examination of the isotopic data in figures 5 to 14 will show that the isotopic compositions of biotites relative to those of anhydrous minerals are quite variable, and can seldom be correlated with metamorphic grade. This behavior is discussed in greater detail in section 7.5 , where isotopic fractionations are compared with metamorphic grade. To examine the possibility that the cationic compositions of the biotites influence their isotopic compositions, the iron to magnesium ratios of several biotites were determined by emission spectroscopy. The $\mathrm{Fe} / \mathrm{Mg}+\mathrm{Fe}$ ratios were then compared with the $\beta$-parameter of the biotites and with the garnet-biotite fractionations. ( $\beta-$ parameters were employed in order to reduce temperature-dependent variations. The $\beta$-parameters of biotites from rocks containing ilmenite instead of magnetite were calculated in accordance with the method outlined in section 7.6.$)$

These comparisons are shown in figure 15. There are no definite systematic correlations between the isotopic and chemical data. Although fractionations between anhydrous and hydrous minerals are irregular, those between muscovite and biotite are relatively uniform (see figure 29). Substitution of $\mathrm{F}$ for $\mathrm{OH}$ is one possible mechanism that may be invoked to explain this behavior. Fluorine content was determined by emission spectroscopy, using the molecular band emission of calcium fluoride. A plot of fluorine content versus biotite-garmet fractionations and the $\beta$-parameter for several biotites is presented in figure 16. It is seen that all the fluorine contents are very low, 
$-103-$

FIGURE 15

$\frac{\mathrm{Fe}}{\mathrm{Mg}+\mathrm{Fe}}$ ratios of biotites compared with isotopic fractionations between the biotites and other minerals 

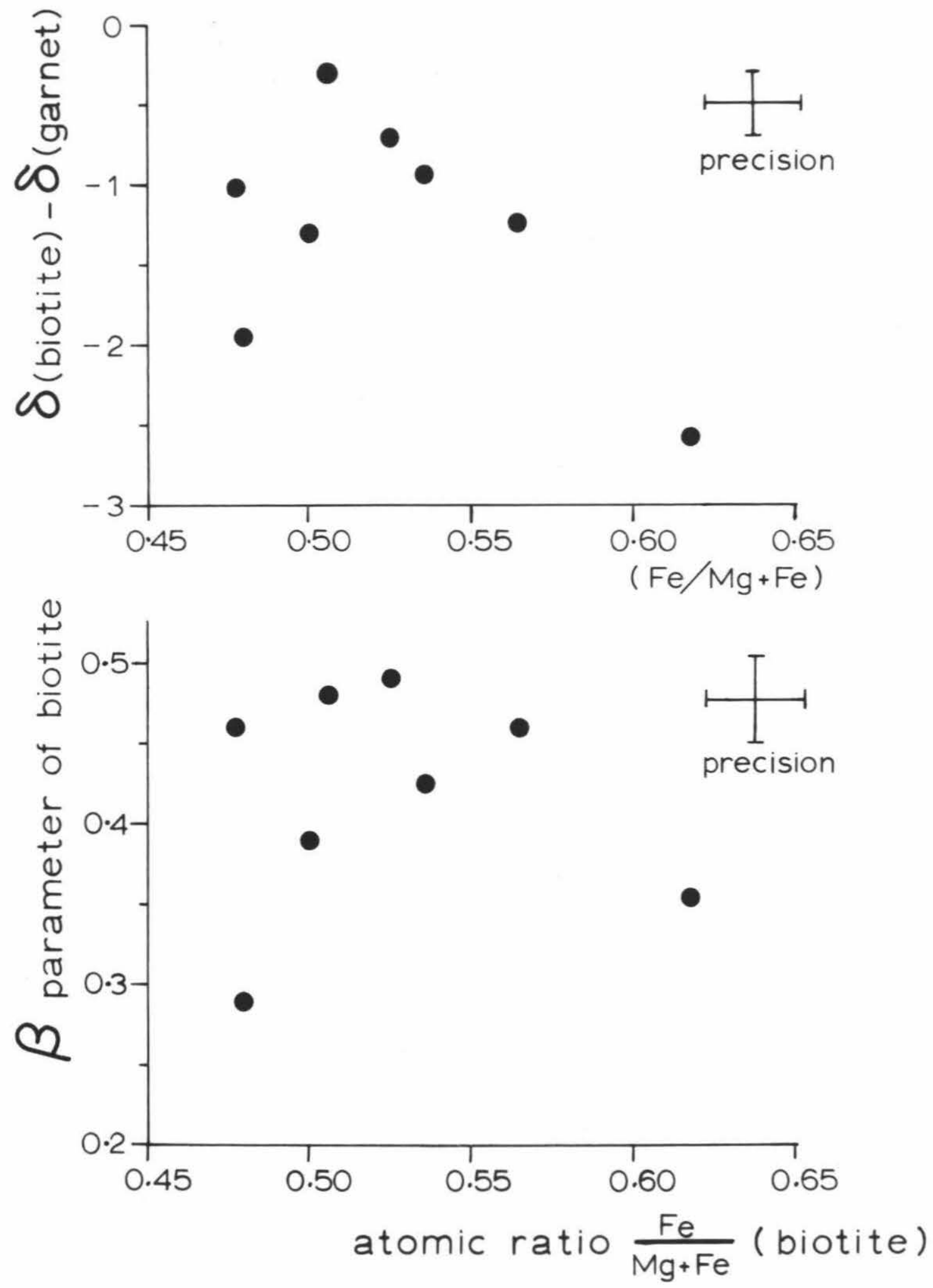
$-105-$

FIGURE 16

Fluorine contents of biotites compared with isotopic fractionations between the biotites and other minerals 

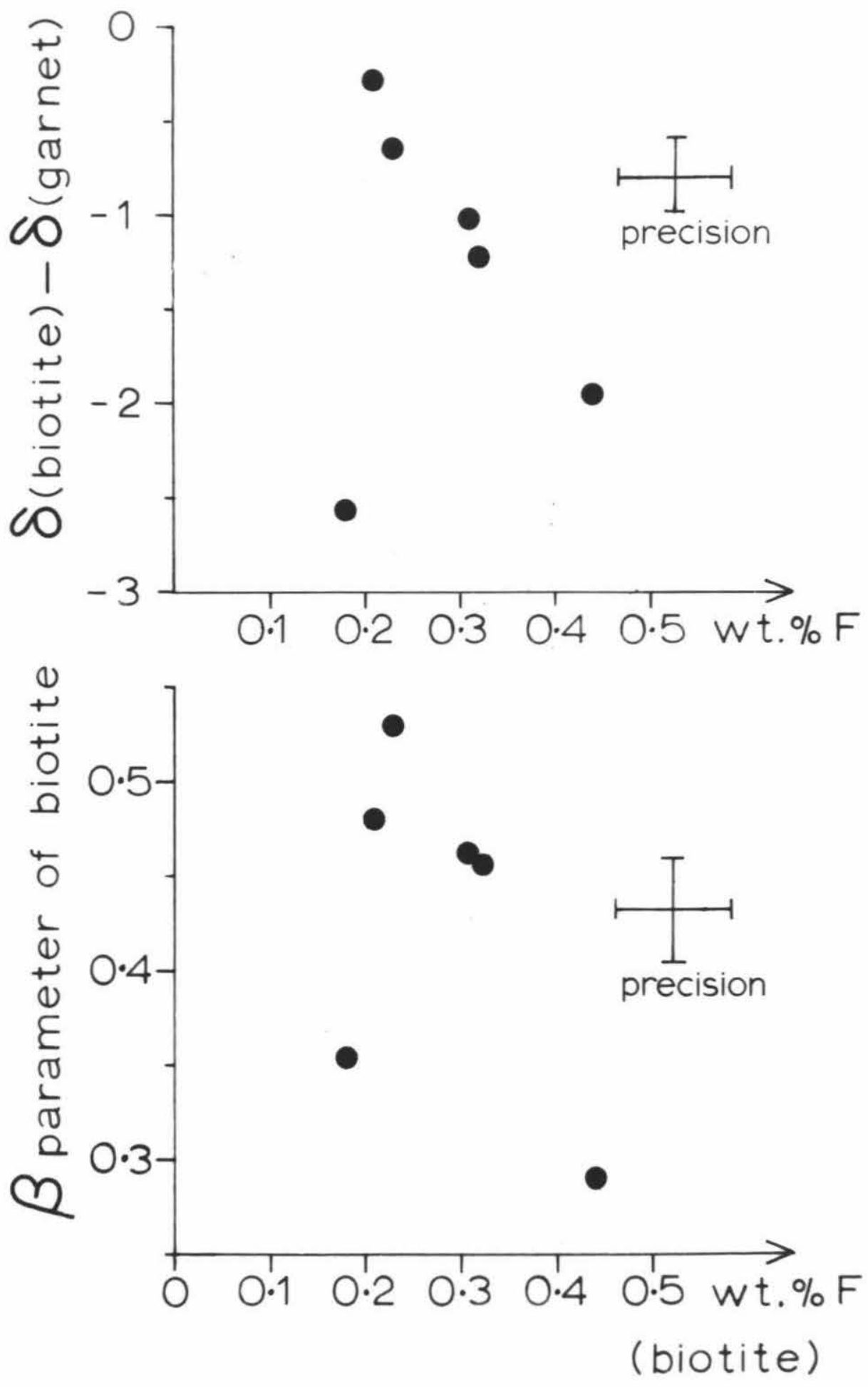

Figure 16 
and there is no definite systematic correlation between the isotopic and chemical data.

We have not considered all the possible variations in chemistry that may influence the isotopic composition of biotite relative to other minerals, but the failure to correlate $\mathrm{Fe} / \mathrm{Mg}$ and $\mathrm{F} / \mathrm{OH}$ ratios with isotopic fractionations encourages us to search for alternative explanations of the erratic isotopic behavior of biotite.

\subsection{Problems of non-equilibrium}

a. General statement

One of the objectives of this investigation is to disentangle equilibrium from disequilibrium effects in the observed fractionations between coexisting minerals.

Three conditions which prevent the observation of equilibrium fractionations among metamorphic minerals should be distinguished:

1) Equilibrium is attained at the thermal maximum, but the isotopic records of equilibrium are not preserved to the present time;

2) Surface equilibrium is maintained between phases during crystallization, but the early-formed cores do not readjust to a changing isotopic or thermal environment at the phase boundaries;

3) Equilibrium is not attained due to the absence of effective exchange mechanisms.

\section{b. Cases of partial isotopic exchange}

One example of the non-preservation of isotopic records established in a schist at the time of regional metamorphism is afforded by 
the case of partial isotopic exchange between a xenolith of schist and an intrusive trondjemite.

The trondjemite occurs as a stock about 150 meters in diameter intruding Precambrian Reading gneiss located within the Chester dome of southern Vermont. The xenolith is one or two meters in diameter, and was presumably derived from the Cavendish formation which is possibly of early Cambrian age. From the geometrical relations between the trondjemite stock and the Cavendish formation, Thompson (79) has estimated that the xenolith descended a distance of 400 meters or more through the magma chamber.

The results of isotopic analyses on three quartz fractions, muscovite, garnet, biotite, and ilmenite are presented in figure 17, where they are compared with analyses of minerals from the Cavendish formation to the north and the Gassetts schist (VE12b), a member of the Cavendish formation, to the southwest.

The isotopic composition of the garnet in the xenolith, assuming that it was originally identical to that in the Gassetts schist, has changed by only 0.5 permil. The other minerals in the xenolith-quartz, muscovite, biotite, and ilmenite--have undergone extensive isotopic exchange with the surrounding trondjemite. Three quartz separates from a kilogram-specimen of the xenolith yielded three quite different isotopic analyses. Quartz separate No. 1 was obtained from mica-rich lenses and has suffered the least exchange of the three. Quartz separates No. 2 and No. 3, hand-picked from $0.3 \mathrm{~cm}$-wide quartz lenses, have experienced more exchange. 
FIGURE 17

Isotopic analyses of minerals from the Cavendish formation compared with those of similar minerals in a xenolith of the Cavendish formation within a stock of trondjemite.

Legend:

๑ quartz

$\triangle \quad K$-feldspar

$\nabla \quad$ plagioclase

$\square$ muscovite

- garnet

biotite

$\square \quad$ ilmenite

- magnetite 


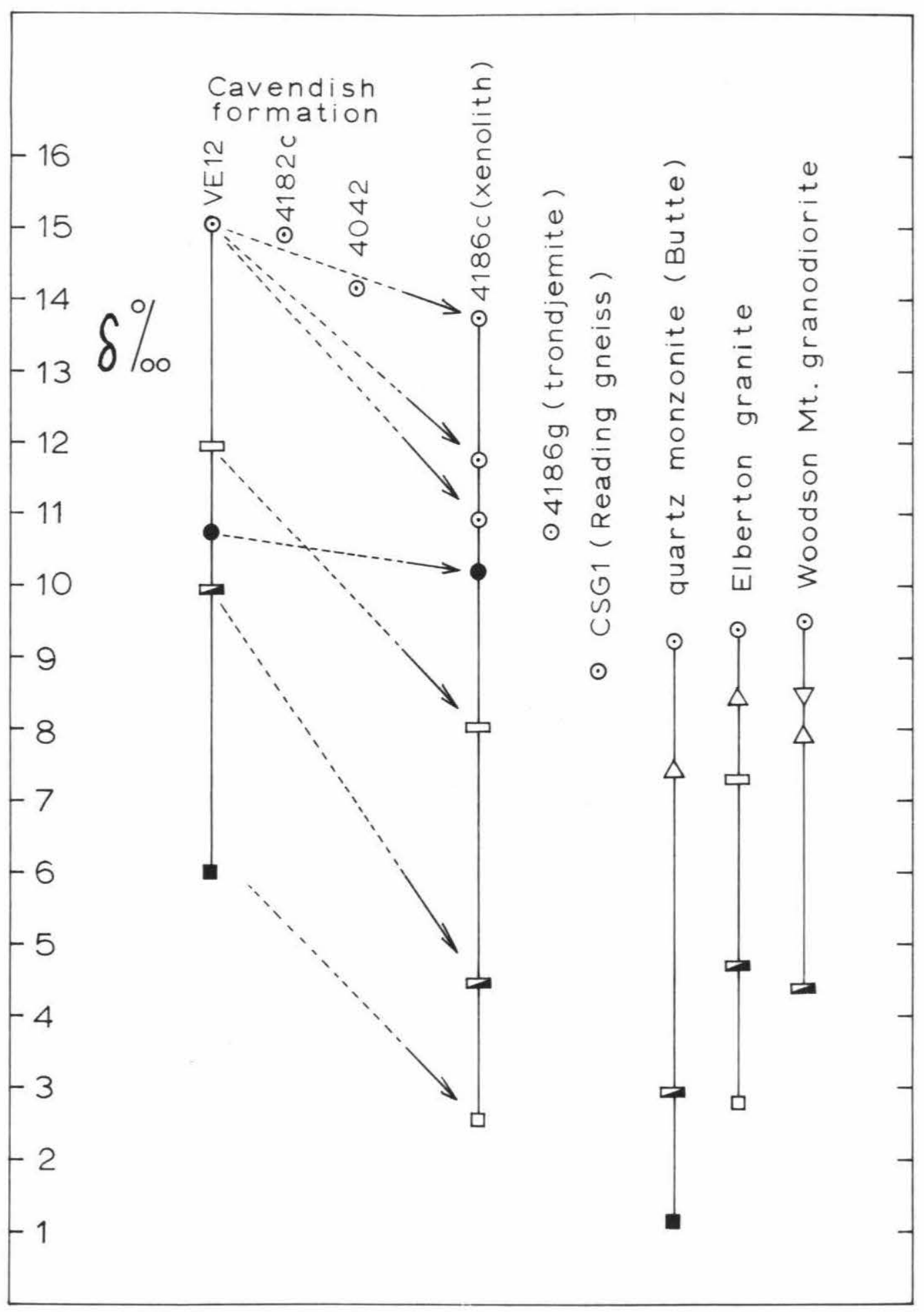


Both macroscopically and under the microscope, the xenolith is similar to the Gassetts schist, except that staurolite is absent, and the quartz shows undulatory extinction under crossed polarizers. Ilmenite occurs as $0.1 \mathrm{~mm}$ grains; the other minerals mentioned have dimensions of about $0.5 \mathrm{~mm}$ to $3 \mathrm{~mm}$. The extent of recrystallization in the xenolith is difficult to ascertain. The muscovite is welloriented, and sweeps around the garnet crystals in a manner characteristic of dynamically metamorphosed schists. This texture is not expected in minerals having crystallized under the approximately hydrostatic conditions prevailing in a magma chamber. It is conceivable, however, that the original orientation, established during regional metamorphism, is preserved after almost complete recrystallization by the seeding influence of the original crystals.

Regardless of the mechanism of exchange, the above observations permit a tentative ordering of the minerals according to their relative ability to resist isotopic exchange under certain magmatic conditions:

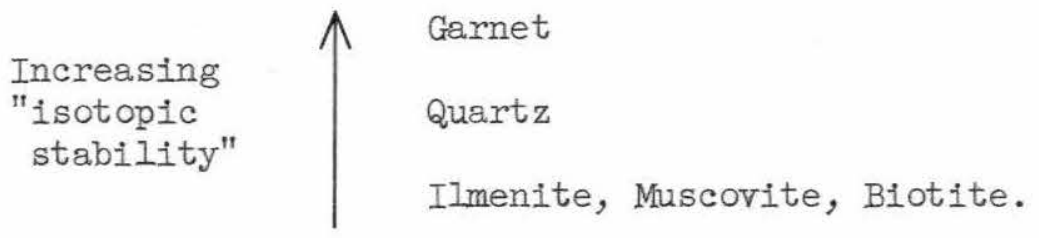

The trondjemite appears to be slightly enriched in $0^{18}$ relative to the isotopic composition of acid igneous rocks, as shown in figure 17. The reason for the enrichment of $0^{18}$ in the trondjemite is not known. The exposed xenoliths are not abundant enough to influence the isotopic composition of the trondjemite. 
Further evidence bearing on the relative resistance of minerals to isotopic exchange is obtained from a study of the wallrock alteration zone adjacent to a hydrothermal quartz-rhodochrosite vein at Butte, Montana. The geology of this region has been described by Sales and Meyer (67). The quartz-rhodochrosite veins are surrounded by sericitic and argillic alteration envelopes. The widths of the alteration envelopes vary with the widths of the veins, and generally become wider as the center of the ore-district is approached.

Figure 18 shows the analyses of quartz and microperthitic microcline from the unaltered quartz-monzonite country-rock compared with the same minerals hand-picked from a sericitic alteration envelope accompanying a quartz-rhodochrosite vein in the Emma Mine. The $0^{18} / 0^{16}$ ratio in quartz from this vein is several permil smaller than the ratios in the quartz and feldspar of the fresh quartz-monzonite. The microcline has experienced much isotopic exchange with the isotopically light hydrothermal fluids, whereas the quartz is unaffected by the alteration process within analytical precision. All the other minerals in the quartz-monzonite have been altered to sericite, quartz, and pyrite. The quartz grains are severely strained, but not obviously recrystallized. The microcline is optically indistinguishable from that in the fresh quartz-monzonite, and both have optic angles of about $55^{\circ}$. However, incipient alteration is evident along cracks in the exchanged microcline. The X-ray diffraction patterns for the fresh and exchanged microcline are identical within analytical error. Careful comparisons with the principal reflection of potassium bromate, 
$-113-$

FIGURE 18

Comparison of isotopic compositions of quartz and microcline from fresh and hydrothermally altered quartz monzonite at Butte, Montana. 


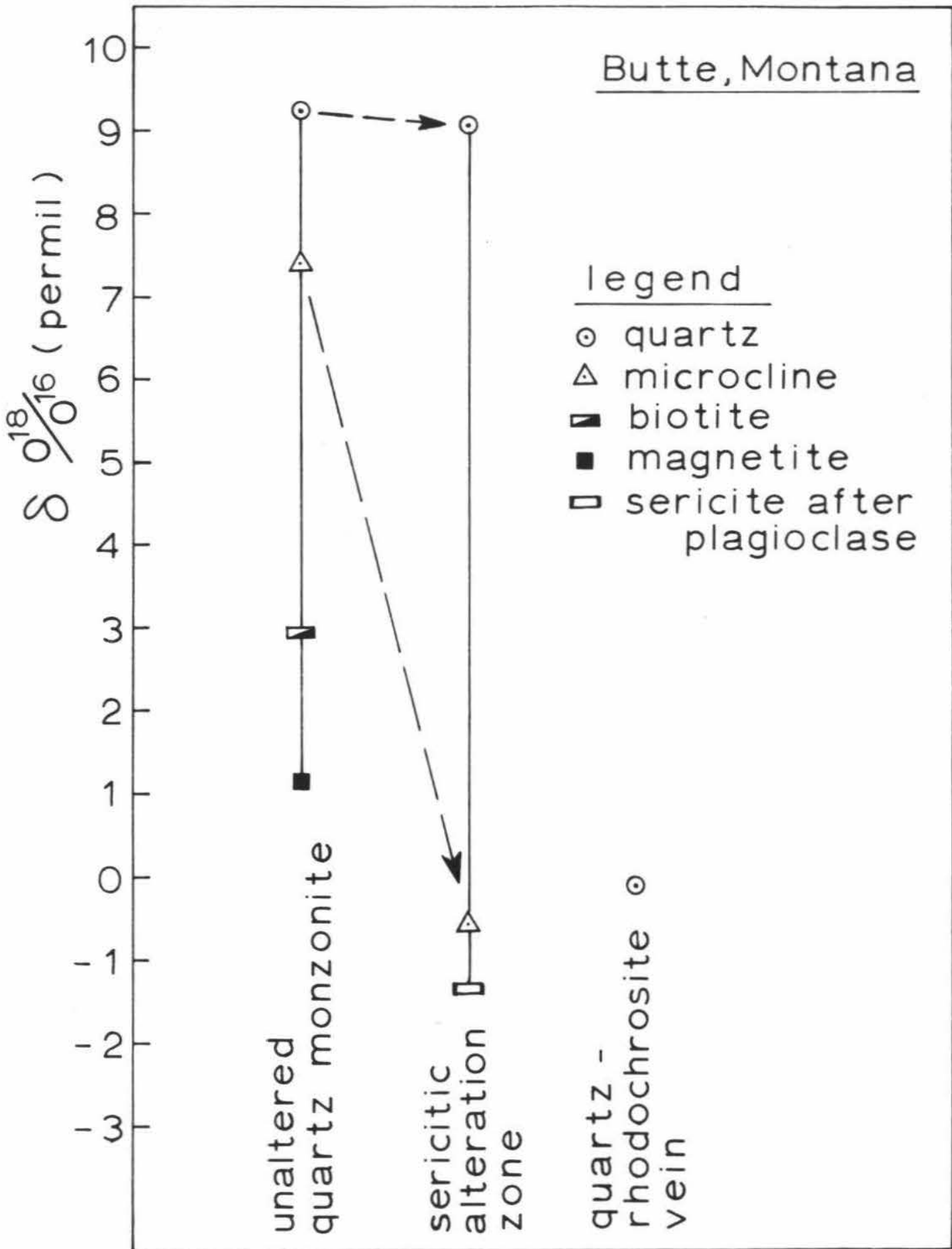


in accordance with the method described by orville (61), failed to reveal any change in the potassium to sodium ratio. The X-ray patterns correspond to those of microcline, though the characteristic microcline twinning is absent in both the fresh and exchanged feldspar. Reflections corresponding to orthoclase and oligoclase were identified in both samples. Non-isotopic evidence for the recrystallization of the exchanged microcline is thus lacking. Whether microcline is stable or metastable in the sericitic alteration envelope is not known, but it is altered to sericite and quartz in similar envelopes within the central regions of the district.

In summary, the data suggest that microcline may experience extensive oxygen-isotopic exchange without showing other evidence of recrystallization, and that isotopic records are more permanent in quartz than in microcline under hydrothermal conditions.

\section{c. Isotopic zoning in garnet}

The crystallization of phases during changing conditions, with incomplete reaction of the early-formed cores with the changing surface conditions, can result in chemically and isotopically zoned metacrysts.

Two large porphyroblasts of gamet--P12a and 1319--were selected as convenient crystals in which to search for isotopic zoning.

Pl2a was collected by J. I. Rosenfeld from the carbonate-bearing Waits River formation east of the Athens dome, Vermont. Garnet and included quartz from three concentric zones were cut from the P12a metacryst as shown in figure 19. The geometry of spirally-arranged 
FIGURE 19

Sketches of a section through garnet porphyroblast P12a showing mineralogy and sample locations.

FIGURE 20

Sections through garnet porphyroblast 1319 showing mineralogy and sample locations.

\section{FIGURE 21}

Isotopic analyses of samples taken from garnet porphyroblasts $\mathrm{P} 12 \mathrm{a}$ and 1319. 


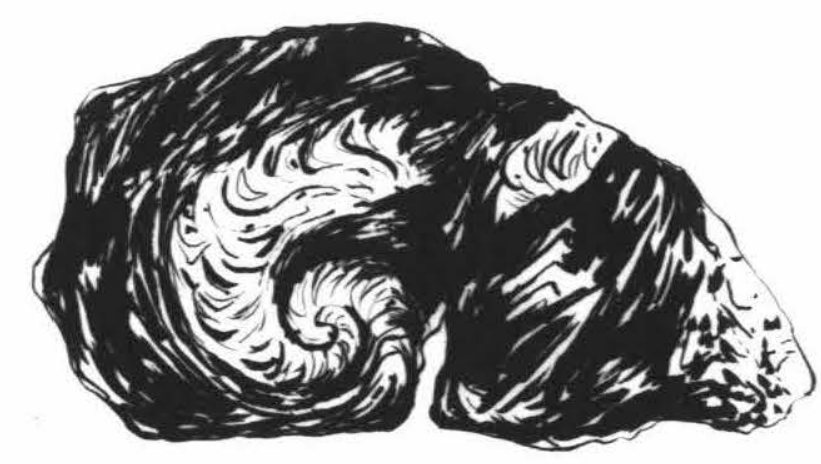

$$
\begin{aligned}
& \text { black = garnet } \\
& \text { white }=\text { quartz }
\end{aligned}
$$

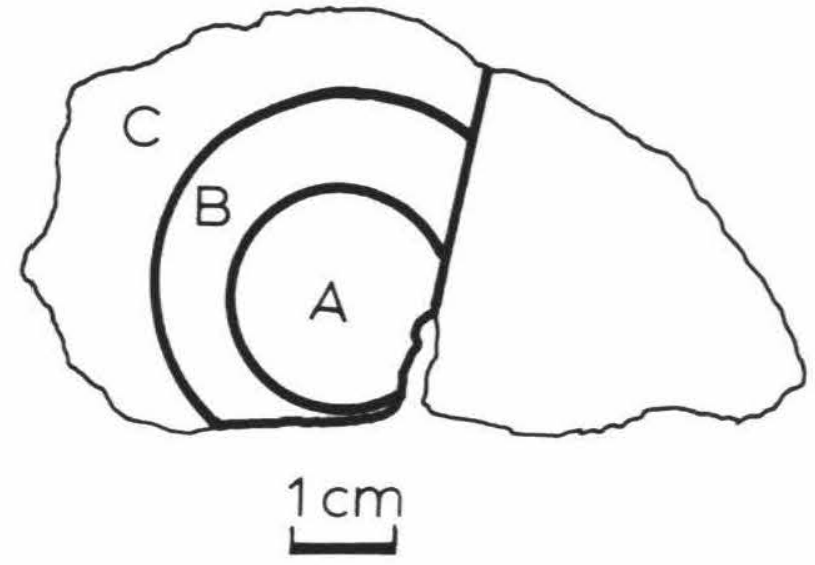

Sketches of $5 \mathrm{~mm}$-thick slice through garnet porphyroblast No. P12a showing mineralogy and sample locations 
Sketches of garnet porpyroblast \# 1319 showing mineralogy and sample locations

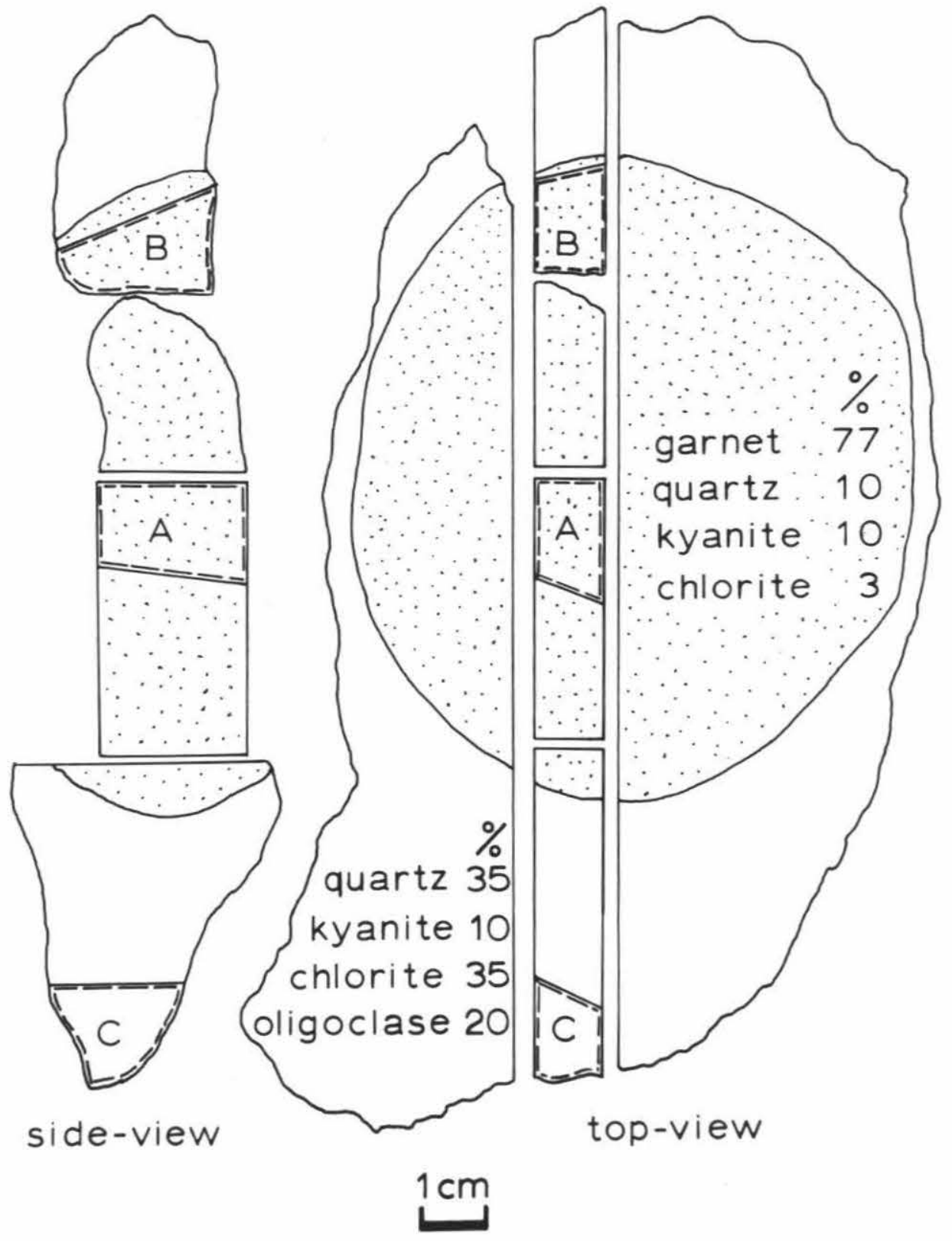


- 119 -

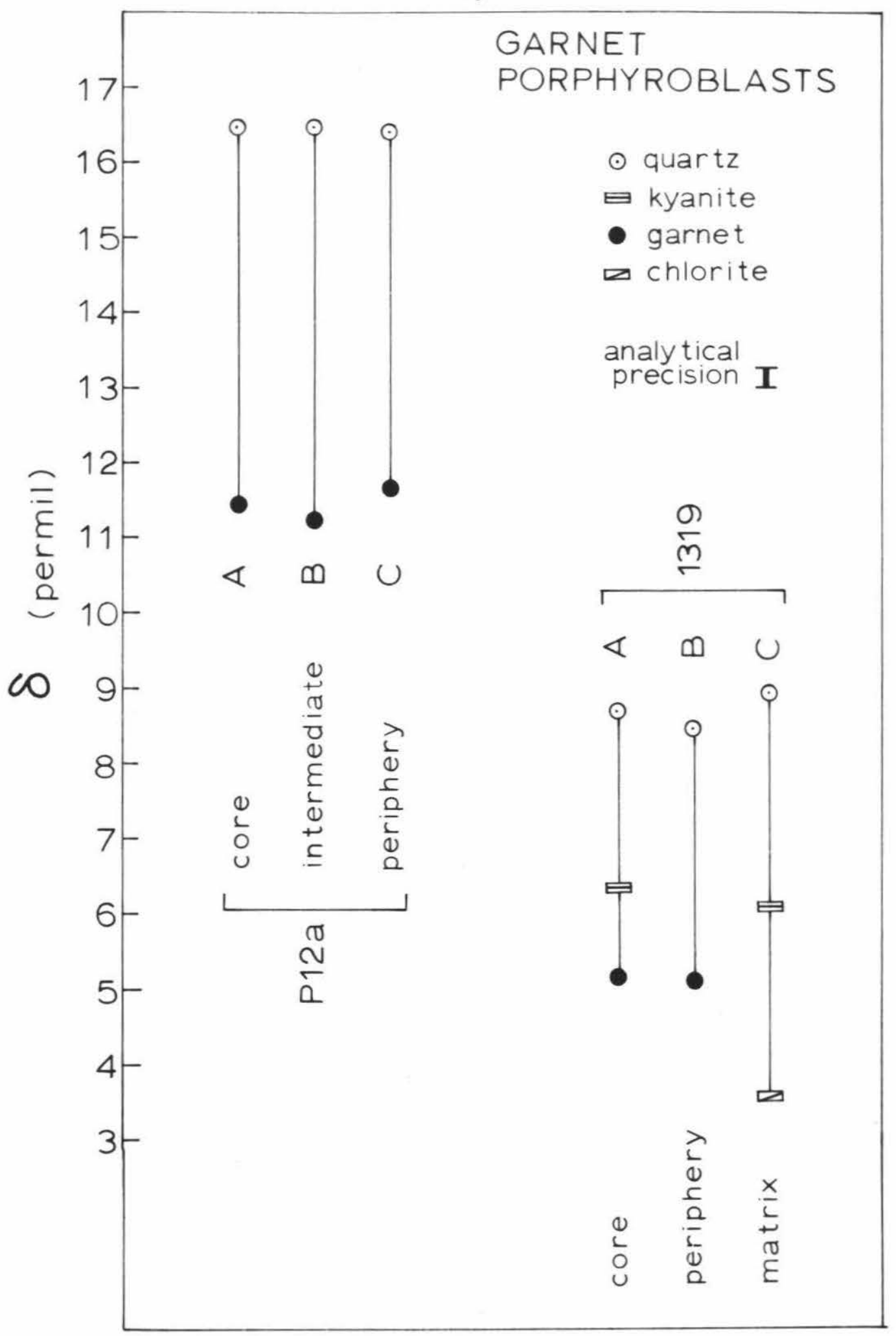

Figure 21 
inclusions in P12a, which reflects the growth stages of the crystal, was used as a guide in sampling the crystal. The pattern of the inclusions indicates that the rock was intensely sheared during the growth of the garnet.

Specimen 1319 was collected by A. Hietamen in Boehls Butte quadrangle, Idaho, from an inclusion of plagioclase-chlorite-kyanitequartz-garnet schist in anorthosite of possible metasomatic origin. The crystal was sampled as shown in figure 20. Garnet samples from the core and periphery of the metacryst were analyzed by emission spectroscopy for iron, magnesium, manganese, and titanium. The only variation detected was a decrease in manganese content from $1.2 \%$ in the core to $0.6 \%$ in the periphery.

Isotopic analyses of these samples from P12a and 1319 are plotted in figure 21. It is seen that isotopic zoning is negligible in both cases. Although a more comprehensive search for isotopic zoning is called for, we will make the interim assumption that the mineral grains in regionally metamorphosed rocks are isotopically homogeneous.

With regard to the determination of isotopic fractionations between isotopically zoned minerals, it should be noted that if the fractionation between mineral surfaces remained constant during crystallization, the fractionation can be readily measured providing the minerals crystallized simultaneously at rates proportional to their final abundances. 


\subsection{Regional homogenization of isotopic composition}

The isotopic analyses of a particular mineral separated from pelitic schists collected within a few hundred meters of one another are usually found to be quite similar, suggesting that isotopic compositions are locally homogenized. Minerals from the following groups of rocks illustrate this behavior:

1) D6 and D7 (Dutchess County);

2) IAI68, LA33, IAIOp, $q$, and $k$ (central Vermont):

3) EVI7s, EVI7a (southern Vermont);

4) F22b and $S 35 j$ (southern Vermont).

When the distances between the rocks are greater, the isotopic compositions are less alike. Lithologic similarity between rocks can also be expected to vary inversely with distance. In certain cases, however, isotopic homogeneity is independent of lithologic uniformity. For example, the rocks from the chloritoid-kyanite zone of central Vermont represent three distinct mineral assemblages, but the isotopic composition of a particular mineral is, within experimental error, the same regardless of which assemblage it occurs in [Taylor et al. (76)]. Another example is the isotopic similarity in quartz from EVI7s, a schist, and EVI7a, an amphibolite, collected within a few meters of one another in southern Vermont.

The progressive dehydration of pelitic sediments during metamorphism liberates water which undoubtedly serves as a medium of exchange between the rocks. If this water were supplemented by "juvenile" water from depth, one would possibly find a decline in the $0^{18} / 0^{16}$ 
ratios of high-grade metasedimentary rocks, because plutonic rocks have $\delta$ values considerably smaller than those of common sedimentary rocks. Of course, equilibrium relationships between the isotopic compositions of rocks and hydrothermal solutions are complicated by temperature. The data of $\mathrm{O}^{\mathrm{I}} \mathrm{Ne} i \mathrm{l}$ and Clayton (60), reproduced in figure 23, are pertinent to this problem.

The dehydration process itself is not expected to have a large effect on the whole-rock isotopic compositions of pelitic schists. At the temperatures of interest, ranging from $400^{\circ} \mathrm{C}$ to $600^{\circ} \mathrm{C}$, water at equilibrium with quartz has $\delta$ values which are 5 to 2 permil smaller than those of the quartz. (See figure 23.) The whole-rock isotopic composition of a typical quartz-garmet-mica schist is also a few permil lighter than its quartz. Thus, the escaping water would probably have an isotopic composition similar to that of the parent rock.

Silverman (71), Schwander (68), and Taylor et al. (75) have reported evidence that the metasedimentary rocks in certain areas have undergone isotopic exchange during metamorphism so as to approach the isotopic compositions of igneous rocks. Further evidence of such a process is found in Dutchess County, and is discussed in section 5.1b. In order to ascertain whether a tendency towards the homogenization of metasedimentary and igneous compositions can be observed on a wider scale, the analyses of minerals from a variety of rocks and metamorphic provinces are compiled in figure 22. The rocks are arranged in approximate order of increasing metamorphic grade. The analyses of minerals from a quartz monzonite (Butte, Montana) are shown for compari- 
FIGURE 22

Isotopic analyses of minerals from metasedimentary rocks representing various provinces. The rocks are arranged in approximate order of increasing metamorphic grade.

Legend:

O quartz

$\square$ muscovite

- garnet

$\square$ biotite

$\square \quad$ ilmenite

- magnetite 


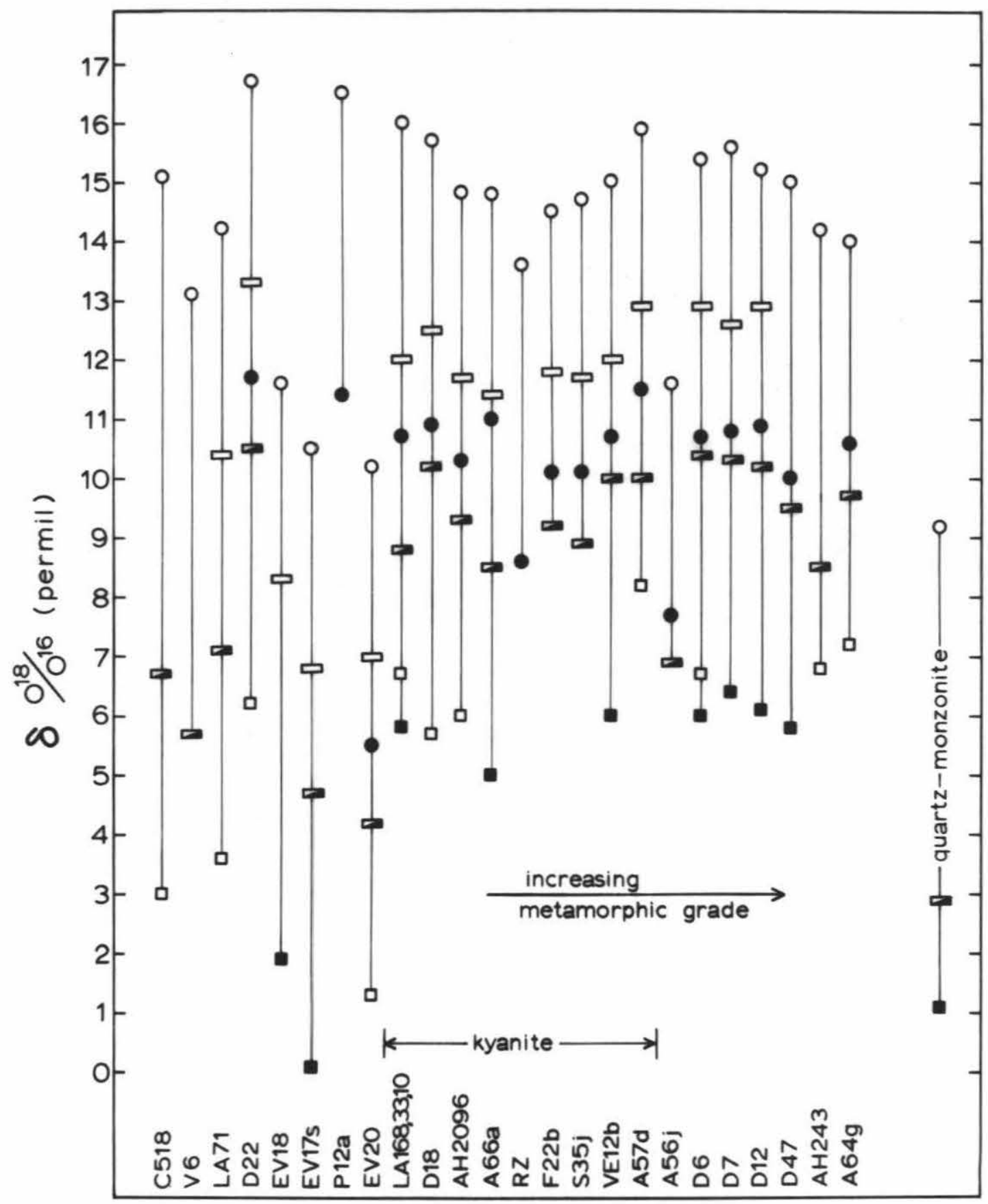

Figure 22 
son. Amphibolites, Precambrian basement gneisses, and schists in immediate contact with igneous rocks are omitted from the compilation. The Precambrian gneisses are excluded because it is often difficult to distinguish paragneisses from orthogneisses in such rocks.

One may have anticipated a tendency for higher-grade rocks to display a smaller range of $\delta$ values and to approach the isotopic compositions typical of igneous rocks. However, no definite trend in the $0^{18} / 0^{16}$ ratios with increasing grade can be discerned, other than the decrease in isotopic fractionations between coexisting minerals. The decrease in overall varlability with increasing grade suggested by the plot may simply reflect the circumstance that 4 of 7 sillimanitegrade rocks were collected from a relatively small region of Dutchess County in which isotopic compositions are fairly uniform. IAl68, IA33, LAIOp, $q$ and $k$ represent another set of adjacent schists with similar isotopic compositions, but have been plotted as one rock. "IA168,33,10" is a hypothetical assemblage of minerals for which isotopic compositions were derived by averaging the measured compositions in LAI68, LA33, LAIOp and q.

Evidence in figure 22 for a general decrease in $\delta$ values with increasing grade is lacking, but the degree of homogenization between metamorphic and igneous rocks need not be proportional to grade. The unusually low $\delta$ values in the schists--EVI8, EVI7s, and EV20--collected from the garnet zone south of the Athens dome in southern Vermont may be a result of isotopic exchange with fluids in communication with, or derived from, igneous rocks. 
This is an exploratory attempt at determining the extent of interlithic isotopic exchange during metamorphism, and its greatest value may be as a guide to further work. However, the evidence does suggest that the isotopic compositions of particular minerals in highgrade rocks are sensibly homogenized over distances measured in hundreds of meters, and that a regional depression of $0^{18} / 0^{16}$ ratios accompanies homogenization in some areas.

\subsection{Amphibolites}

The amphibolites found in metamorphic rocks may originate from different parent rocks via different processes [Engel and Engel (25)].

1) Primary crystallization of hydrous, mafic melts;

2) Metamorphism of mafic, intrusive or extrusive rocks;

3) Metasomatism of carbonate sediments;

4) Metamorphic differentiation. Amphibolites derived from igneous rocks are termed ortho-amphibolites; those derived from sedimentary rocks are termed para-amphibolites. The $0^{18} / 0^{16}$ ratios in amphibolites are potentially useful in determining their origins. For example, the oxygen in ortho-amphibolites is likely to be impoverished in $0^{18}$ relative to the oxygen in surrounding metasediments. Amphibolites developed during metamorphism as a result of segregation should be in isotopic equilibrium with their host rocks.

Whether amphibolites derived from carbonate sediments will be isotopically heavier or lighter than surrounding metasediments cannot be predicted because of the large number of variables involved. In 
particular, the preferential loss of $0^{18}$ accompanying decarbonation may have an unpredictable effect on the isotopic composition of the residual solids.

$\delta$ values of quartz from five amphibolites are shown in table 9, together with the isotopic compositions of quartz from adjacent schists.

TABIE 9

Isotopic compositions of quartz from amphibolites and adjacent schists

\begin{tabular}{lrcc}
\hline \hline & $\begin{array}{c}\text { Amphibolite } \\
\text { No. }\end{array}$ & Pelitic schist \\
(quartz) & No. \\
\hline D46 & 9.5 & 15.0 & D47 \\
EV17a & 10.8 & 10.5 & EV17s \\
RCC & 11.9 & 13.6 & RZ \\
A15h4 & 10.8 & 11.6 & A56j \\
1321 & 9.1 & $(14.8$ & AH2096) \\
\hline
\end{tabular}

The isotopic data are compatible with igneous ancestries for all these amphibolites, though other origins are not excluded. The isotopic compositions of quartz in EVI7a and EVI7s appear to have been homogenized, but the $\delta$ value of EVI7a is similar to that of igneous rocks.

Since rock No. 1321 (Shoshone County, Idaho) is surrounded by anorthosite possibly of matasomatic origin, it is not very meaningful to compare its isotopic composition with that of metasediment. However, the isotopic composition of this amphibolite and the field relationships are consistent with an origin involving igneous rocks. 


\section{CHAPTER VII}

GEOTHERMOMETRY

\subsection{Introduction}

Before the isotopic fractionations in natural assemblages can be used to indicate temperatures of formation, criteria must be available whereby the attainment and retention of equilibrium can be verified, and the equilibrium fractionation factors must be known as functions of temperature. The latter information is obtained in the laboratory by equilibrating synthetic or natural minerals with one another or with common exchange-media.

Equilibrium in natural systems is assumed to have obtained if the fractionations between different mineral pairs from the same assemblage yield the same temperature on the basis of experimentally determined fractionations. However, the experimental data required by this approach are not available. The only minerals pertinent to this work which have been adequately studied in the laboratory are quartz and magnetite. Therefore, assumptions regarding the attainment and retention of equilibrium isotopic distributions rest upon the observations of systematic isotopic variations from mineral to mineral and on their compatibility with geological and theoretical considerations.

\subsection{Temperature dependence of quartz-magnetite fractionations}

Because isotopic fractionations between quartz and magnetite are commonly larger than those between any other analyzed mineral pair, 
with the possible exception of quartz and hematite, the quartz-magnetite geothermometer is potentially the most temperature-sensitive. The suitability of the quartz-magnetite geothermameter is further enhanced by the occurrence of these minerals throughout a wide range of geological conditions.

The experimental determinations of quartz-water and magnetitewater fractionations reported by 0 'Neil and Clayton (60) are presented In figure 23. Analyses of quartz crystals synthesized from quartzseeded silica gel in 0.8 molar sodium fluoride solutions are shown as circled points. The arrows at $500^{\circ} \mathrm{C}$ and $350^{\circ} \mathrm{C}$ indicate the suspected directions from which equilibrium was approached. The arrows and bars associated with the quartz curve at $600^{\circ} \mathrm{C}, 700^{\circ} \mathrm{C}$, and $800^{\circ} \mathrm{C}$ represent the approaches to equilibrium achieved with powdered quartz as starting material.

The magnetite was synthesized by decomposing ferrous carbonate in water at high temperature. The arrows under the magnetite curve indicate the directions from which equilibrium was approached. The curve is extrapolated towards the measured composition of magnetite obtained from the radulae of chitons grown in ocean water at $9^{\circ} \mathrm{C}$.

The solid curve in figure 25 is derived from figure 23 and represents quartz-magnetite fractionations as a function of temperature.

It should be noted that $0^{\prime} \mathrm{Ne} 11$ and Clayton continue to investigate the quartz-magnetite system in the laboratory, and the present calibration may be refined when more data become available. 
$-130-$

FIGURE 23

Experimental wuartz-water and magnetite-water fractionations as functions of temperature. [0'Neil and Clayton (60).] Ilmenite-water fractionations are inferred from analyses of quartz, ilmenite, and magnetite in natural assemblages. 
- 131 -

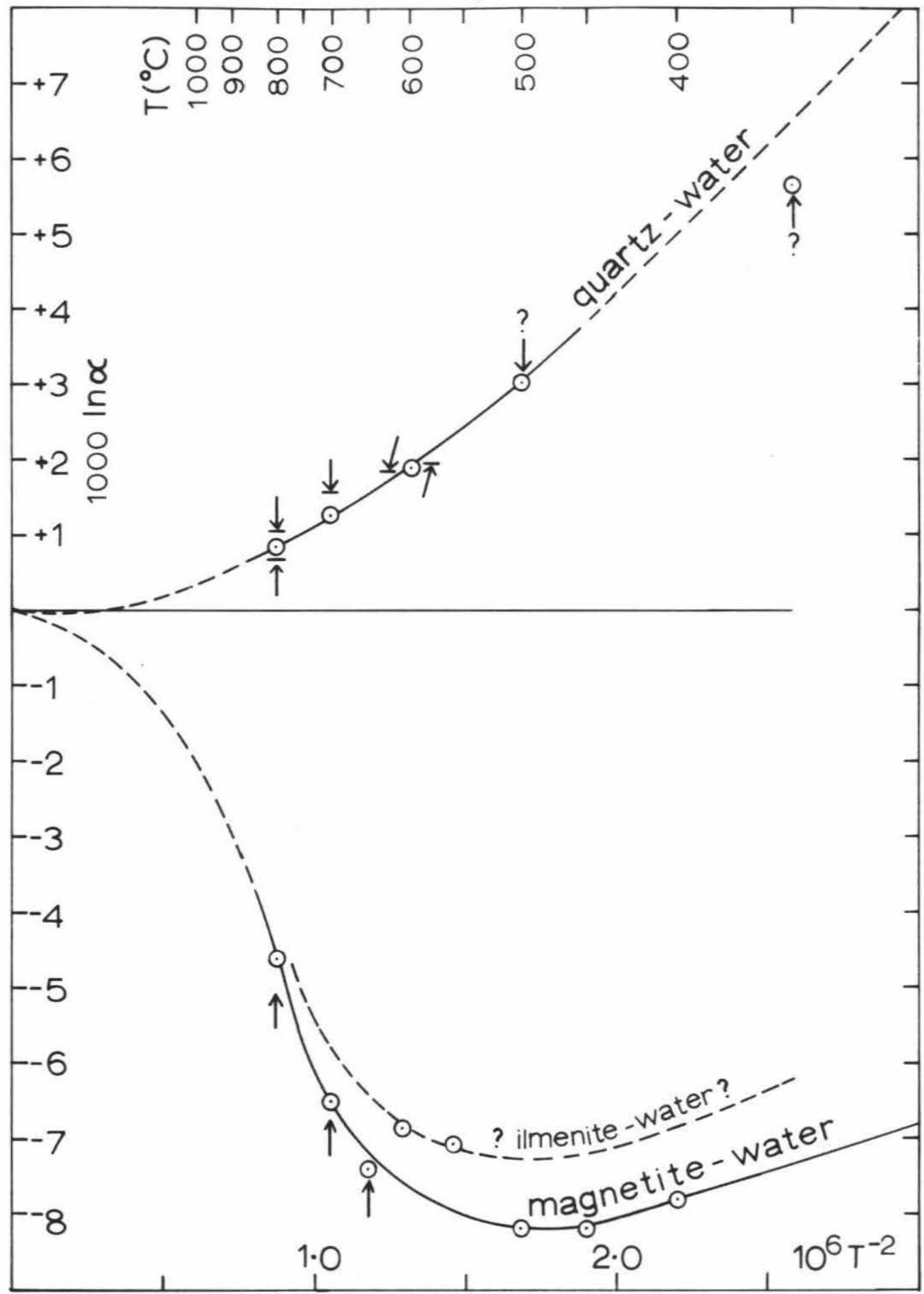

Figure 23 


\subsection{Temperature dependence of quartz-ilmenite}

fractionations

In those rocks that contain very little magnetite, it is often more convenient to analyze ilmenite. An attempt was therefore made to determine quartz-ilmenite fractionations as a function of temperature by comparing them with quartz-magnetite fractionations measured in rocks with similar thermal histories. Rock D6, from the staurolitesillimanite zone of Dutchess County, is suited to this purpose because it contains both ilmenite and magnetite in discrete grains. This rock yielded quartz-ilmenite and quartz-magnetite fractionations of 8.7 and 9.4 permil, respectively. Rock D7, occurring one hundred meters to the east of D6, yielded a quartz-magnetite fractionation of 9.3 permil, in good agreement with the fractionation in D6. A second comparison was obtained from two rocks separated from one another by 230 meters, but occurring in a terrain of uniform metamorphic grade and isotopic homogeneity (see section 5.2 ). These rocks represent the chloritoidkyanite grade, and were collected near Mount Grant, Addison County, central Vermont. The quartz-ilmenite fractionation of 9.3 permil in rock LAl68 and the quartz-magnetite fractionation 10.2 permil in rock LA33 are assumed to represent the same temperature of formation. Quartzilmenite fractionations of 9.3 and 9.2 permil measured by Taylor et al. (76) in rocks LAIOp and IAIOq attest to the isotopic consistency in the area.

On the basis of these two comparisons, quartz-ilmenite fractionations are assumed to be $92 \%$ as large as quartz-magnetite fractiona- 
tions throughout the temperature range of interest, and the dashed curves of figures 23 and 25 are constructed. In other words, the $\beta$ parameter for ilmenite is assumed to be constant and equal to 0,08 .

A sufficient condition for the assumption of constant $\beta$-parameter to be valid is that the logarithm of each fractionation factor be proportional to the same function of temperature for each mineral pair:

$$
\begin{aligned}
& \text { In } \alpha_{M}^{I}=C_{1} f(T) \\
& \text { In } \alpha_{M}^{Q}=C_{2} f(T),
\end{aligned}
$$

where $I, M$, and $Q$ denote ilmenite, magnetite, and quartz, and $C_{1}$ and $C_{2}$ are constants. Then,

$$
\beta(\text { ilmenite })=\frac{\text { In } \alpha_{M}^{I}}{\ln \alpha_{M}^{Q}}=\frac{C_{1}}{C_{2}} .
$$

The assumption of a constant $\beta$-parameter for ilmenite is a temporary measure intended to extend the temperature-calibration of quartz-magnetite fractionations to quartz-ilmenite fractionations.

\subsection{Retention of isotopic records}

The application of isotopic techniques to geological thermometry is dependent upon the preservation of isotopic records established in minerals during their formation.

The resistance of quartz to isotopic exchange under magmatic and hydrothermal conditions has been discussed in section 6.3. Quartz appears to be less disturbed by certain changes in environment than 
microcline, muscovite, biotite, and ilmenite, but more disturbed than garnet.

The laboratory experiments of $0^{\prime} \mathrm{Neil}$ and Clayton (60) with powdered natural minerals suggest that quartz exchanges with water more readily than magnetite, but neither exchange rate is appreciable over periods of a few days at temperatures below $600^{\circ} \mathrm{C}$. The rates of exchange in these experiments may be roughly proportional to the recrystallization rates. However, complete exchange with powdered, natural magnetite was not achieved in any of the experiments, although significant recrystallization was observed at $800^{\circ} \mathrm{C}$. Equilibrium could only be approached with the use of finely divided magnetite prepared from powdered ferrous carbonate by decomposition in water at high temperatures.

The observations mentioned above suggest that the isotopic records in quartz, garnet, and magnetite are more permanent than those in muscovite, biotite, feldspar, and ilmenite. Of course, exchange rates will vary with environment, so the above conclusions are tentative.

Observed regularities in the isotopic fractionations between ilmenite, quartz, and garnet indicate that the isotopic records established in ilmenite are as well-preserved as those in quartz and garnet. For example, the average value of the ratio ( $\left.\delta_{\text {garnet }}{ }^{-\delta_{\text {ilmenite }}}\right) /$ $\left(\delta_{\text {quartz }}-\delta_{\text {ilmenite }}\right)$, obtained from 8 rocks (the xenolith, $4186 \mathrm{c}$, is not included), in which these minerals were analyzed, is 0.52 , and the average deviation from this value is only 0.025 . This variation is within the limits of analytical precision. 


\subsection{Indicated temperatures of metamorphism}

The validity of the isotopic thermometry described here depends upon the accuracy of the experimental data, the assumption that pressure effects are negligible, and the assumption that isotopic equilibrium was attained among certain minerals at a single temperature in rocks with long thermal histories. The absolute temperatures quoted in this section are therefore uncertain, but many of the conclusions reached are valid if the measured isotopic fractionations are considered to yield relative temperatures only.

Before the quartz-magnetite and quartz-ilmenite fractionations are used to rank the rocks according to their indicated temperatures of formation, it is instructive to rank them, as best we can, by means of the available geological information. The isotopic fractionations between quartz and other minerals in 14 regionally metamorphosed rocks are arranged according to relative metamorphic grade in figure 24. Rocks in which neither magnetite nor ilmenite were analyzed are not considered.

Four rocks showing mineralogical evidence of retrogradation are omitted from the compilation, and are plotted separately in figure 29. These include EV17s, EV18, and EV2O, in which garnets are extensively replaced by secondary chlorite. EVI2b is omitted because it contains magnetite intimately associated with ilmenite and rutile, and shows some chloritization of garmet and biotite. Also excluded is a Precambrian quartzite (GBF3), from the Green Mountains (southern Vermont) which was probably metamorphosed before the Cambrian to the sillimanite 
$-136-$

FIGURE 24

Isotopic fractionations between quartz and other minerals in rocks arranged in approximate order of increasing metamorphic grade. 
$-137-$

Isotopic fractionations between quartz and:

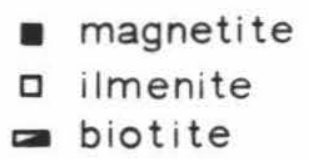

- garnet

$\square$ ilmenite
$\square$ biotite muscovite

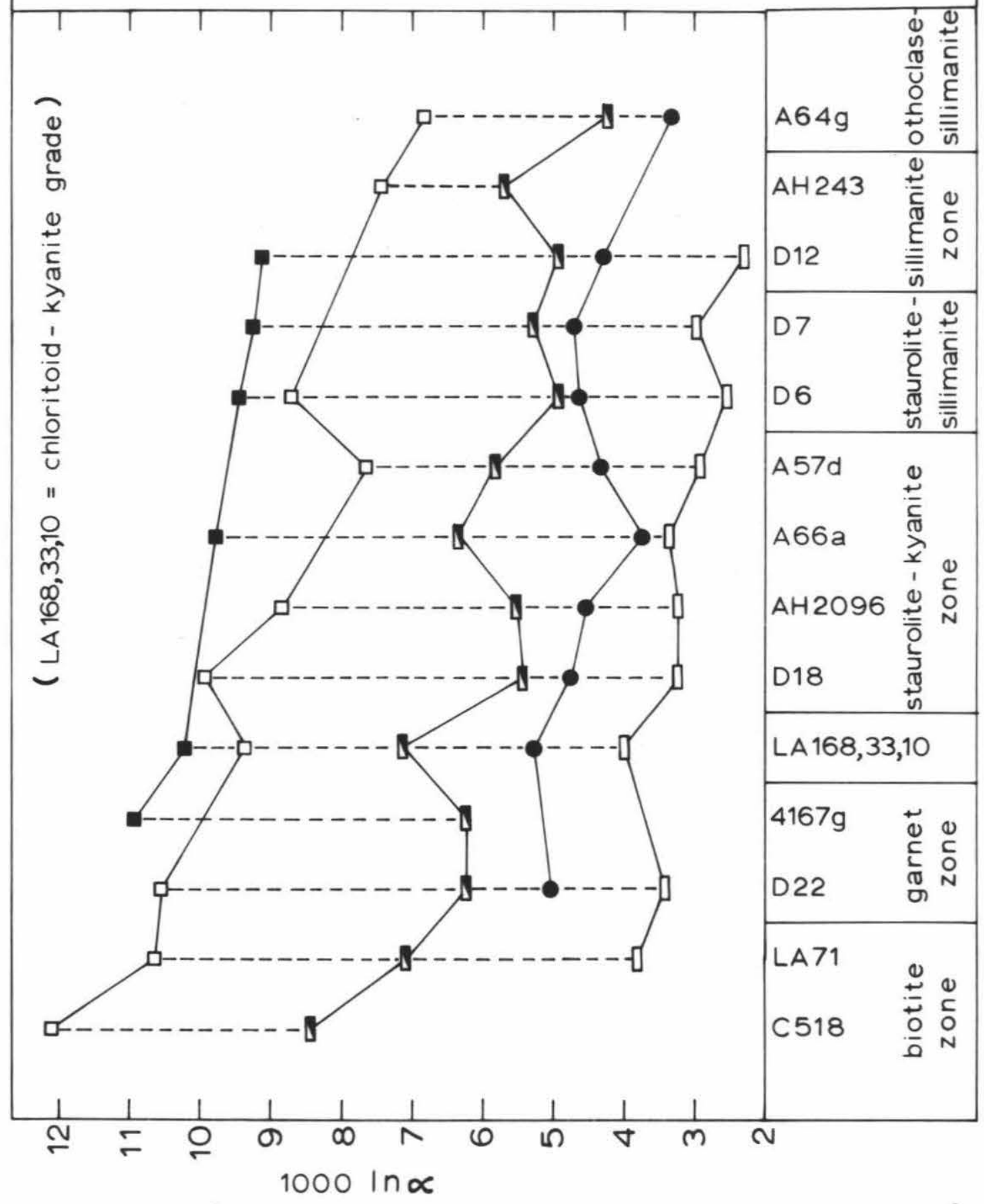


grade, and later subjected to biotite-grade metamorphism during the Paleozoic.

Rock $4167 \mathrm{~g}$ is a gneiss from the Green Mountains with a history similar to that of $\mathrm{GBF}$, but is retained in the compilation because it was remetamorphosed to the garnet grade, and is presumably recrystallized to a greater extent than GBF3. $4167 \mathrm{~g}$ contains unchloritized, euhedral garnets attributed to the Paleozoic metamorphism. There is a possibility that $\mathrm{AH} 243$, located about $10 \mathrm{~km}$ northwest of the Idaho batholith, has also experienced two metamorphic events. Hietanen (39) suggests that regional metamorphism during the Jurassic was followed by metasomatism, associated with the emplacement of the batholith, during the Cretaceous. However, there is little petrographic evidence of retrogradation in this rock, and it is therefore retained in the compilation.

It should be noted that the arrangement shown in figure 24 need not correspond to one of increasing temperature of formation. In particular, the chloritoid-kyanite grade in central Vermont need not represent a lower temperature than the staurolite-kyanite grade in Dutchess County.

The compilation shows that fractionations between quartz and other minerals analyzed tend to decrease with increasing grade. Quartzmagnetite fractionations appear to be the most regular. The regularity of quartz-ilmenite fractionations is marred by A57d, a coarse-grained quartzite from central Connecticut collected from a kyanite zone sandwiched between sillimamite zones. 
In figure 25, the rocks are arranged in order of their apparent temperatures of formation by plotting their quartz-magnetite and quartz1lmenite fractionations on the appropriate curves derived from figure 23. The quartz-biotite, quartz-garmet, and quartz-muscovite fractionations are then plotted at the temperatures defined by their associated quartzmagnetite or quartz-ilmenite fractionations.

The apparent stability ranges of the index minerals-biotite, garnet, staurolite, kyanite, sillimanite, and K-feldspar (in the presence of sillimanite)--are shown at the base of figure 25. Two inconsistencies arose in making this plot:

1) A57d (central Connecticut) represents the staurolitekyanite zone, but plots at a higher temperature than D12 (Dutchess County) which contains garnet and sillimanite;

2) Chloritoid, rather than staurolite, is the stable phase appearing in the assemblages represented by LAI68,33,10. Since the rocks composing this diagram were collected from widely scattered metamorphic provinces, it is interesting that conflicts between paragenesis and relative isotopic temperature are not more frequent. Isograds need not parallel the isotherms existing at the time of metamorphism, and the temperature required for the appearance or disappearance of a particular mineral may vary markedly from one province to another. The two inconsistencies mentioned above may reflect differences in rock pressure or the activity of water prevailing at the time of metamorphism, rather than errors in the isotopically-determined temperatures. This is particularly true in the case of IAl68,33,10. 
$-140-$

FIGURE 25

Indicated temperatures of metamorphism obtained by plotting quartz-magnetite and quartz-ilmenite fractionations on curves derived from figure 23. Fractionations between quartz and other minerals are plotted at the temperatures defined by their associated quartz-magnetite or quartz-ilmenite fractionations. 
- 141 -

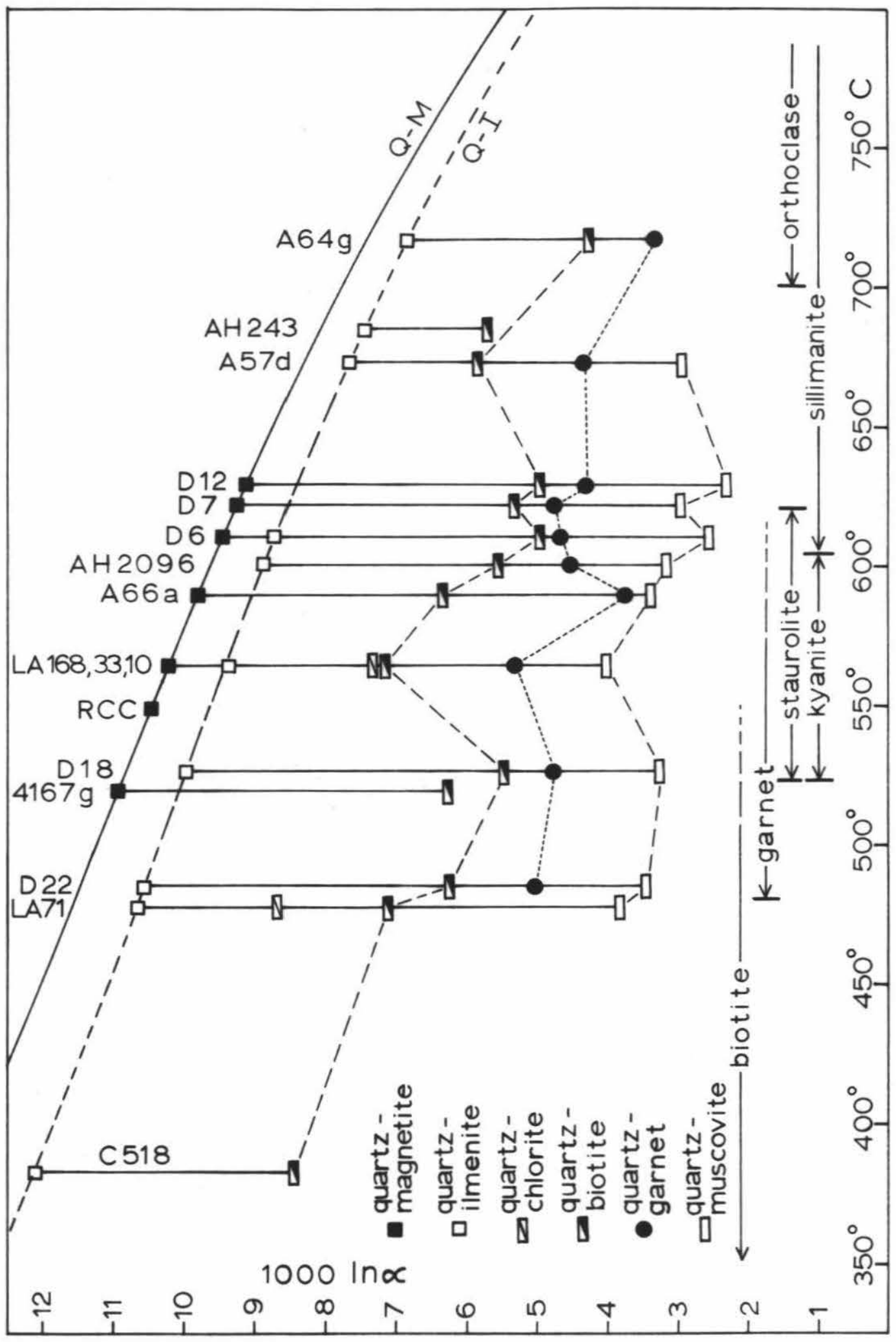


In summary, quartz-magnetite and quartz-ilmenite fractionations in non-retrograded metasedimentary rocks are found to decrease with increasing metamorphic grade, though there are a few exceptions to this behavior. Isotopic temperatures based on the quartz-magnetite scale indicate that regionally metamorphosed pelitic schists from the staurolite-kyanite or chloritoid-kyanite zones have crystallized at temperatures ranging from $520^{\circ} \mathrm{C}$ to $600^{\circ} \mathrm{C}$.

Quartz-garnet fractionations are fairly regular, probably reflecting the high degree of isotopic stability in these two minerals. The one garnet composition which appears to be anomalous occurs in the clough quartzite of connecticut. The reason for the unexpectedly high $0^{18} / 0^{16}$ ratio in this garnet is not known. It is interesting to note that the one quartz-ilmenite fractionation that is decidedly anomalous (A57d) was also obtained from the Clough quartzite of central Connecticut. No other quartzites are represented in the compilation.

The quartz-biotite fractionations plotted in figures 24 and 25 are not as regular as the quartz-garnet fractionations, but it is clear that the quartz-biotite and quartz-muscovite fractionations exhibit sympathetic variations reflecting fairly constant muscovite-biotite fractionations. It appears that muscovite and biotite form a group having an isotopic behavior different from that of the group consisting of quartz, garnet, ilmenite, and magnetite. This grouping is particularly evident when the isotopic compositions of minerals in LAl68, 33, 10 are compared with those in D6. 
FIGURES 26 AND 27

Relationships between fractionations. Assemblages containing extensively chloritized garnets are represented by open circles. The straight lines pass through the origins.

\section{FIGURE 28}

Comparison between muscovite-biotite and garnet-biotite fractionations in rocks arranged in approximate order of increasing metamorphic grade. 

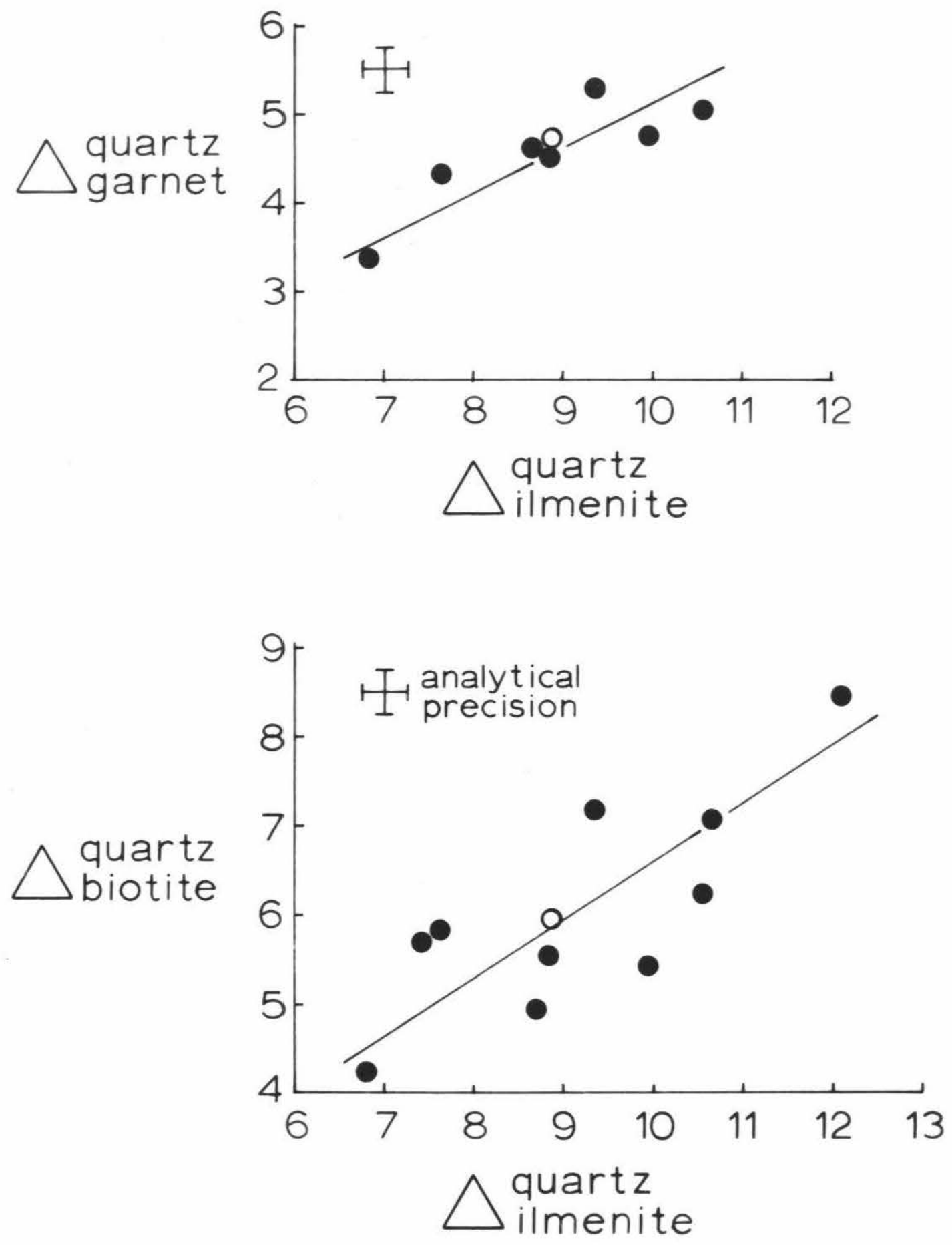

Figure 26 


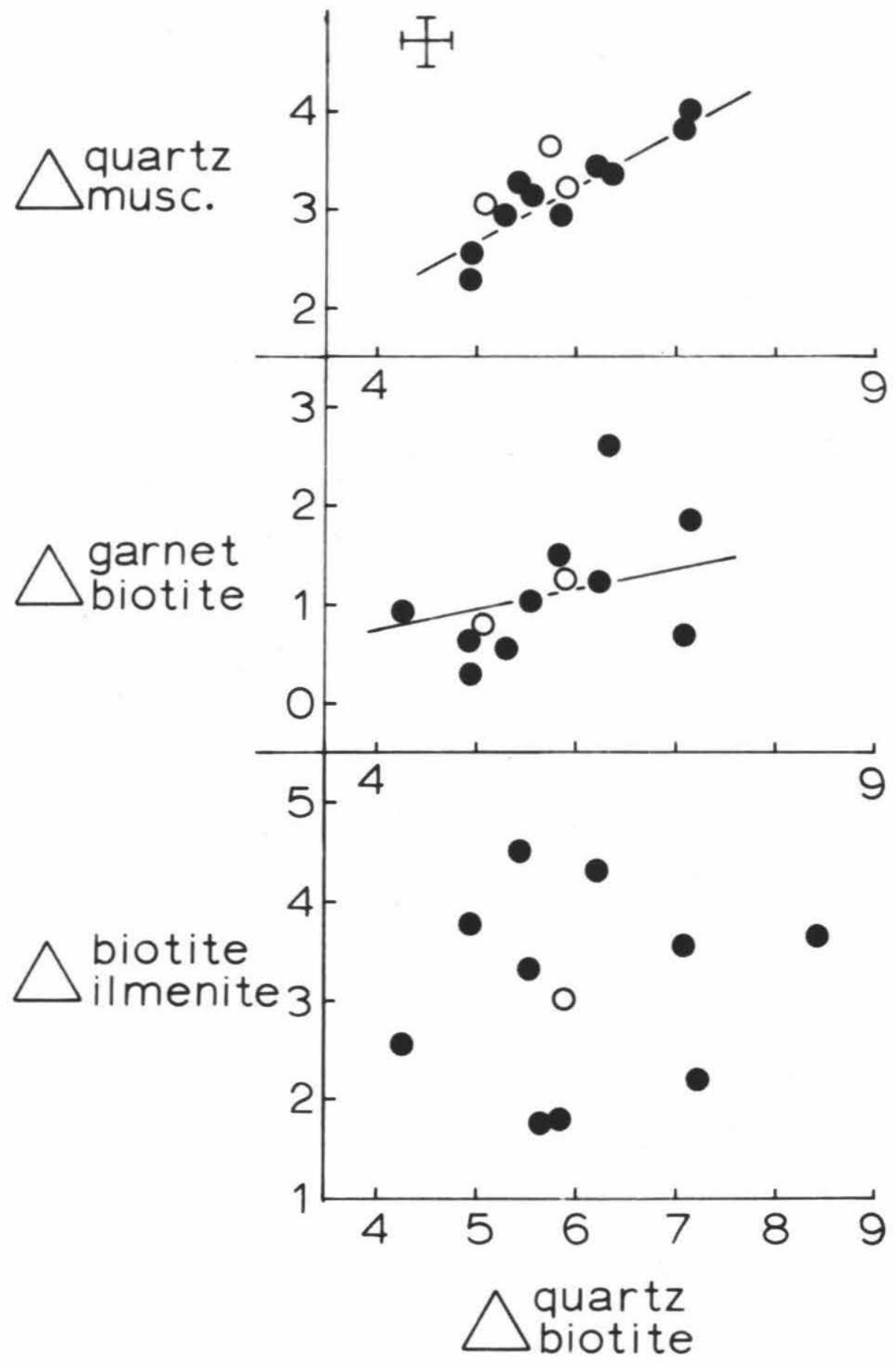

Figure 27 


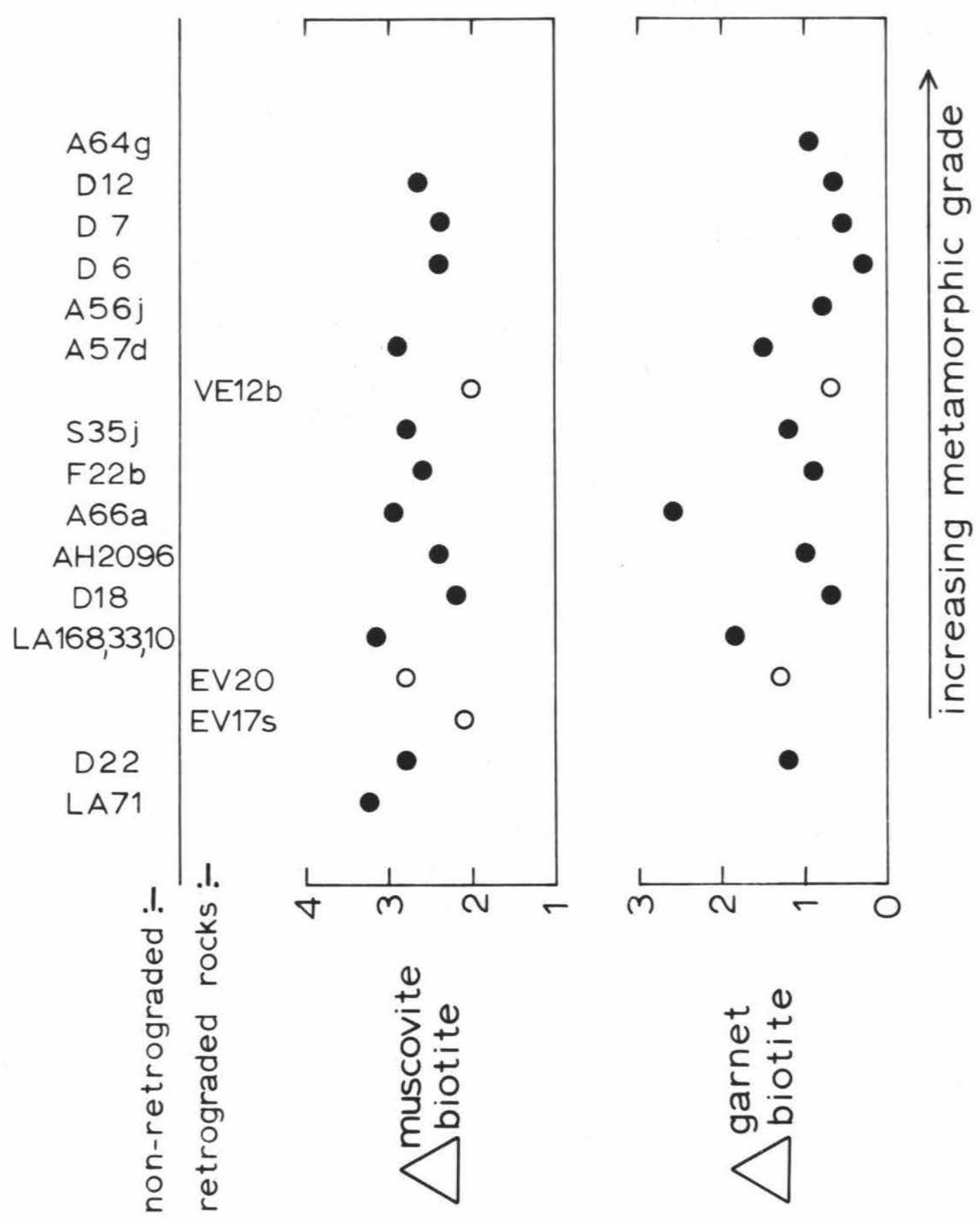

Figure 28 
The above relationships are clarified in figures 26, 27, and 28. These plots show that fractionations involving quartz, garnet, and ilmenite, or quartz, muscovite, and biotite, are intermally consistent, but that fractionations between these two groups of minerals are irregular.

We can now ask the question: which of the two groups of minerals will best reflect the temperatures of formation of metamorphic rocks? Quartz-magnetite and quartz-ilmenite fractionations were used in figure 25, and yielded relative temperatures which were approximately compatible with metamorphic grade in all but one case (A57d). Quartzbiotite fractionations are used in a similar manner in figure 29 . It is clear that the sequence obtained by arranging the rocks according to the magnitudes of their quartz-biotite fractionations is quite different from that obtained from their quartz-ilmenite fractionations. Moreover, the sequence cannot be as readily reconciled with metamorphic grade as determined by geological criteria. In particular, LA168,33,10, $\mathrm{A} 66 \mathrm{a}$, and $\mathrm{AH} 243$ plot at anomalous positions in the sequence.

One explanation of these findings presumes that the hydrous minerals exchange isotopes more readily than the anhydrous minerals analyzed, and thus stabilize their isotopic compositions at lower tem-peratures. With regard to this problem it is interesting to note that the muscovite-biotite fractionation of 2.6 permil in the Elberton granite [Taylor and Epstein (74)] is identical to the average muscovitebiotite fractionation in the pelitic schists of this survey. 
FIGURE 29

Metamorphic rocks arranged in accordance with their quartz-biotite fractionations.

Legend:

- quartz-magnetite

$\square \quad$ quartz-1lmenite

$\times$ quartz-biotite

- quartz-garnet

$\square$ quartz-muscovite 


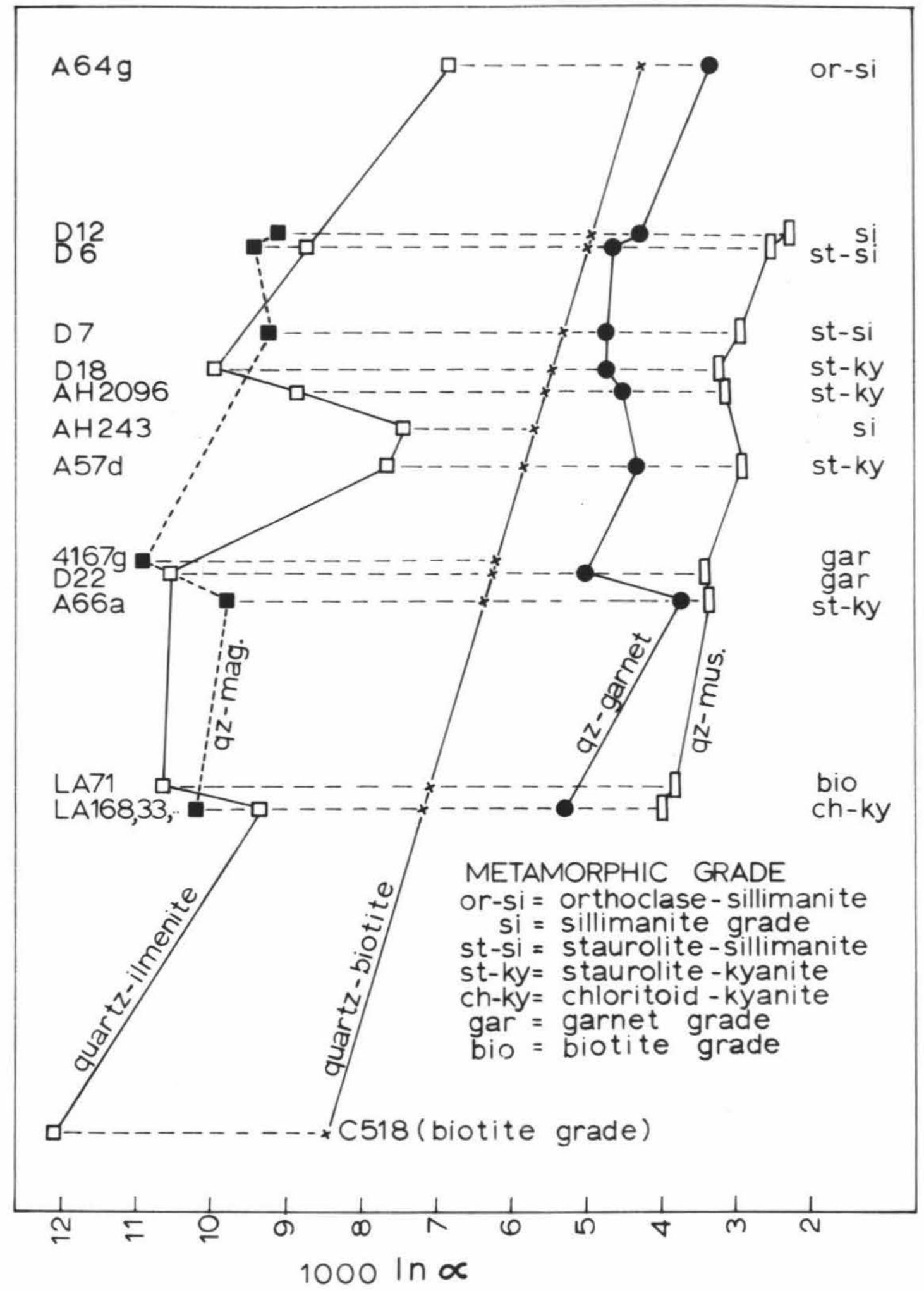




\subsection{Variations in $\beta$-parameter}

As a first attempt at understanding the variations in the $\beta$ parameters of muscovite, biotite, and garnet we will investigate the possibility that a part of the variation is due to temperature. Figure 30 shows curves of constant $\beta$-parameter selected to represent the quartzbiotite, quartz-garnet, and quartz-muscovite fractionations plotted in figure 25. Since the general trends of the points in figure 25 parallel the curves of constant $\beta$-parameter in figure 30, the data are compatible with the assumption that the $\beta$-parameters are independent of temperature.

In our search for other factors which may influence $\beta$-parameters we confine our interest to biotite, because this mineral was analyzed more often than muscovite or garnet, and because the $\beta$-parameter of biotite is the most variable. Unfortunately, magnetite was not analyzed sufficiently often to permit the calculation of many $\beta$-parameters. We therefore extend the use of $\beta$-parameters to rocks in which ilmenite was analyzed by assuming that the $\beta$-parameter of ilmenite equals 0.08 , or

$$
\left(\delta_{\text {quartz }}{ }^{-\delta_{\text {magnetite }}}\right) \approx 1.09\left(\delta_{\text {quartz }}{ }^{-\delta_{\text {ilmenite }}}\right) .
$$

Hence,

$$
\beta(\text { biotite }) \approx \frac{\delta_{\text {biotite }}-1.09 \delta_{\text {ilmenite }}+0.09 \delta_{\text {quartz }}}{1.09\left(\delta_{\text {quartz }}-\delta_{\text {ilmenite }}\right)} .
$$

The $\beta$-parameters of biotite in the pelitic schists of this survey are shown in table 10, together with the $\beta$-parameters in two quartzites and two igneous rocks. 
- $151-$

FIGURE 30

Curves of constant $\beta$-parameter chosen to represent the quartz-biotite, quartz-garnet and quartz-muscovite fractionations plotted in figure 25. 


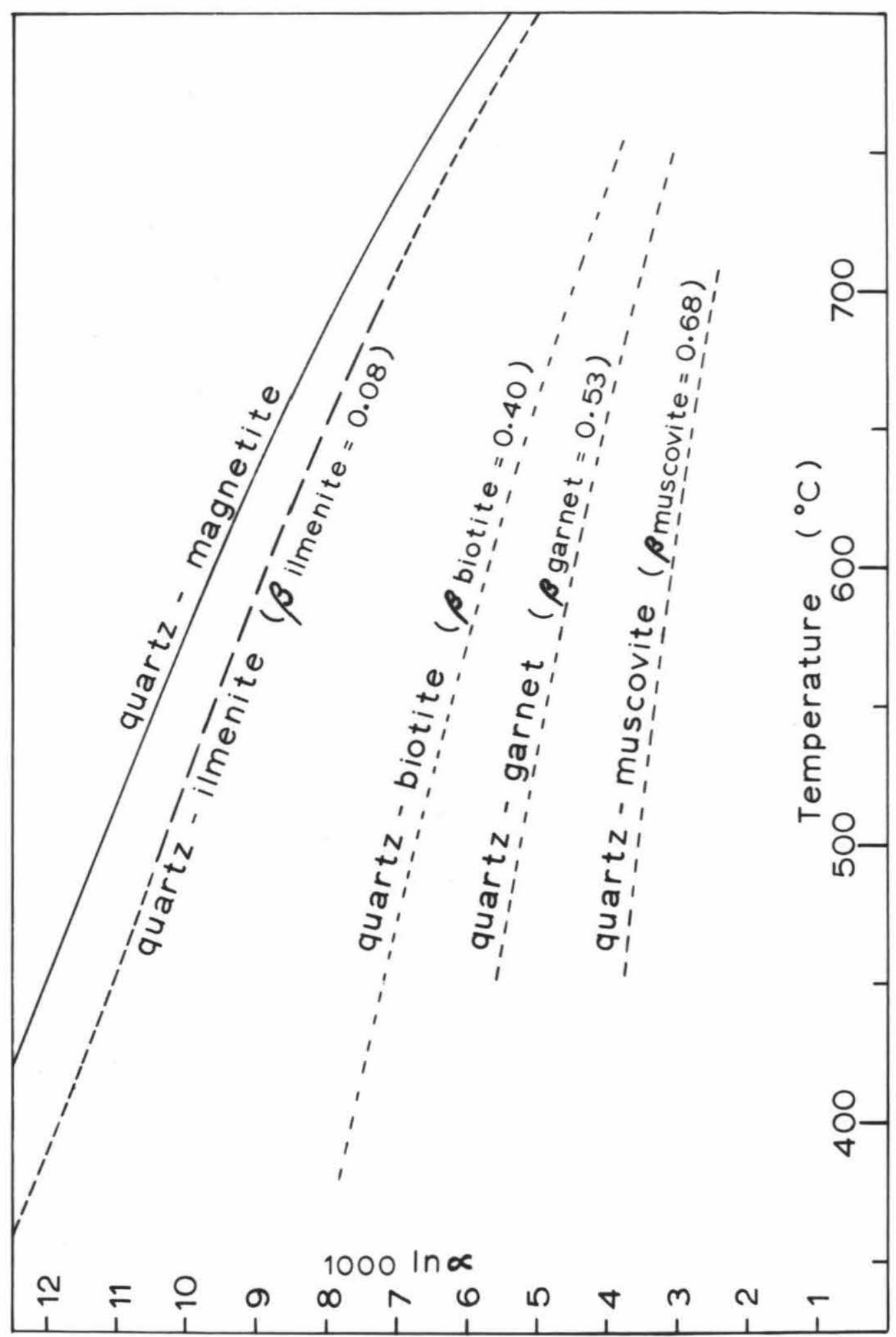


TABLE 10

$\beta$-parameters of biotite

\begin{tabular}{|c|c|c|c|c|}
\hline Locality & Rock & Grade & $\beta$ (biotite) & Average \\
\hline $\begin{array}{l}\text { Central } \\
\text { Connecticut }\end{array}$ & $\begin{array}{l}\text { A66a } \\
\text { A57a } \\
\text { A64g }\end{array}$ & $\begin{array}{l}\text { kyanite } \\
\text { kyanite } \\
\text { sillimate }\end{array}$ & $\begin{array}{l}.36 \\
.30 * \\
.42 * 7\end{array}$ & $0.33 \pm .03$ (quartzite) \\
\hline Idaho & $\begin{array}{l}\text { AH2096 } \\
\text { AH2 } 43\end{array}$ & $\begin{array}{l}\text { kyanite } \\
\text { sillimate }\end{array}$ & $\begin{array}{l}.43 * \\
.30 *\end{array}$ & $0.40+.04$ \\
\hline $\begin{array}{l}\text { Southerm } \\
\text { Vermont }\end{array}$ & $\begin{array}{l}\text { EV17s } \\
\text { EV2O } \\
\text { VE12b }\end{array}$ & $\begin{array}{l}\text { garnet } \\
\text { garnet } \\
\text { kyanite }\end{array}$ & $\begin{array}{l}.44 \\
.39 * \\
.44\end{array}$ & $.0 \pm .04$ \\
\hline $\begin{array}{l}\text { Dutchess } \\
\text { County }\end{array}$ & $\begin{array}{l}\text { D22 } \\
\text { D18 } \\
\text { D6 } \\
\text { D7 } \\
\text { D12 } \\
\text { D47 }\end{array}$ & $\begin{array}{l}\text { garmet } \\
\text { kyanite } \\
\text { sillimate } \\
\text { sillimate } \\
\text { sillimate } \\
\text { sillimate }\end{array}$ & $\left.\begin{array}{l}.46 * \\
.49 * \\
.48 * * \\
.43 \\
.46 \\
.40\end{array}\right]$ & $0.45 \pm .03$ \\
\hline $\begin{array}{l}\text { Central } \\
\text { Vermont }\end{array}$ & $\begin{array}{l}\text { C518 } \\
\text { LA711 } \\
\text { LAI68 } \\
\text { LAI0g }\end{array}$ & $\begin{array}{l}\text { biotite } \\
\text { biotite } \\
\text { kyanite } \\
\text { kyanite }\end{array}$ & $\begin{array}{l}.36 * \\
.39 * \\
.26 * \\
.29 * 4\end{array}$ & $0.32 \pm .05$ \\
\hline $\begin{array}{l}\text { Georgia } \\
\text { Montana }\end{array}$ & $\begin{array}{c}\text { Granite } \\
\text { Quartz Monzonite }\end{array}$ & $\begin{array}{l}\text { igneous } \\
\text { igneous }\end{array}$ & $\left.\begin{array}{l}.35^{*+} \\
.22\end{array}\right]$ & $0.28 \pm .06$ (igneous) \\
\hline
\end{tabular}

* Related to quartz-ilmenite rather than quartz-magnetite. ${ }^{*}$ Related to both quartz-ilmenite and quartz-magnetite.

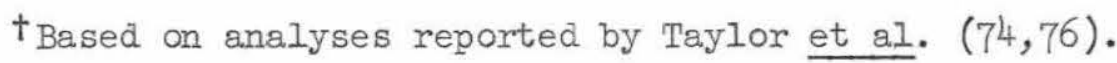


The data in table 10 show that the $\beta$-parameters of biotite in Dutchess County schists are quite different from those in schists collected from central Vermont. The difference is not attributed to differences in the behavior of quartz, ilmenite, or magnetite, because the $\beta$-parameters of garnet in the two areas are similar:

$\begin{array}{cc}\stackrel{\text { Rocks }}{\text { Average } B \text { (garnet) }} & \frac{\text { Av2, D18, D6, D7, D12, D47 }}{\text { D22 }} \\ \text { IA33, IA10p } & 0.49 \pm .02 \\ \end{array}$

The significance of the regional dependence of the $\beta$-parameter of biotite is not clear, but it may concern regional variables such as the thermal or mechanical histories of the rocks, or the presence of water during the temperature decline.

The $\beta$-parameters of biotite in the two plutonic igneous rocks are similar to those in the central Vermont schists, and significantly different from those in Dutchess County. Once again, our present knowledge is not sufficient to permit an explanation.

\subsection{Isotopic effects of retrogradation}

The 4 retrograded rocks plotted in figure 31 compose a sequence of quartz-magnetite and quartz-ilmenite fractionations which is consistent with metamorphic grade. However, the indicated temperatures are slightly higher than those of comparable grades derived from the nonretrograded rocks plotted in figure 25. In order to facilitate comparison between the two sets of data, the indicated stability fields of the index minerals are transposed from figure 25 to figure 31 . Also plotted 
Quartz-magnetite and quartz-ilmenite fractionations in retrograded rocks plotted on curves derived from figure 23. Fractionations between quartz and other minerals are plotted at the temperatures indicated by their associated quartz-magnetite or quartz-ilmenite fractionations. The stability fields of various minerals shown at the base of the figure were transposed from figure 25 for purposes of comparison. 


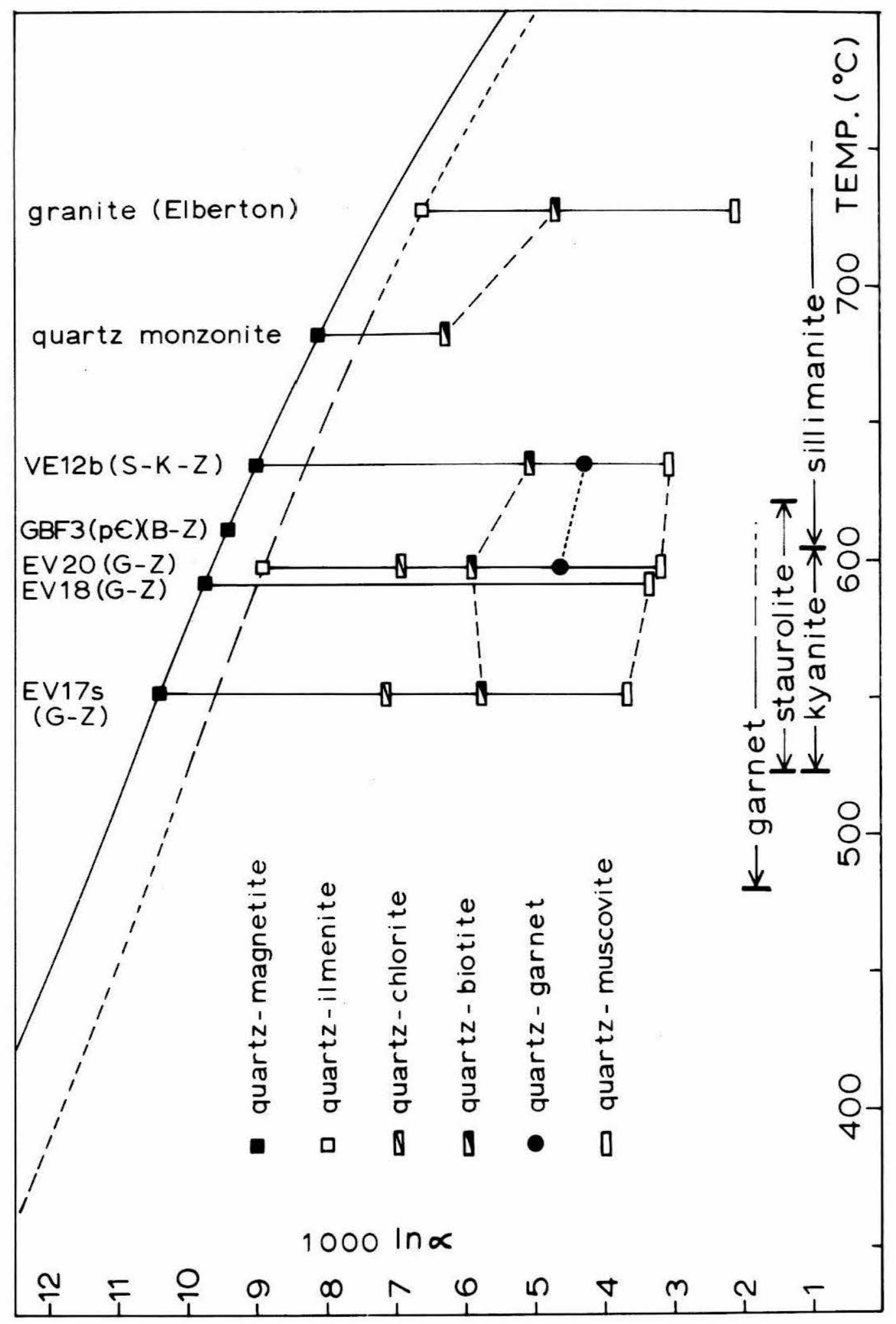

Figure 31 
in figure 31, for purposes of comparison, are two igneous rocks and one Precambrian quartzite (GBF3).

Although quartz-magnetite and quartz-ilmenite fractionations appear to be slightly smaller in retrograded rocks, no other criteria have been noted in the isotopic data that would distinguish the retrograded from the non-retrograded rocks. Consider, for example, the $\Delta$ versus $\Delta$ plots of figures 26 and 27 . Points representing retrograded and non-retrograded rocks have similar distributions in these plots. Moreover, as shown in table 11, the isotopic data do not even distinguish primary chlorite from chlorite pseudomorphing garnet. Of course, significant isotopic differences between retrograded and non-retrograded rocks may become evident when more minerals and rocks have been studied.

\section{TABLE 11}

Isotopic comparison of primary and secondary chlorite

\begin{tabular}{lllccc}
\hline \hline Rock & Grade & Chlorite & $\delta$ garnet & $\delta$ chlorite & $\Delta \begin{array}{c}\text { garnet } \\
\text { chlorite }\end{array}$ \\
\hline LA33 & kyanite & primary & 10.5 & 8.4 & 2.1 \\
S35j & kyanite & primary & 10.1 & 7.3 & 2.8 \\
EV20 & garnet & secondary & 5.5 & 3.2 & 2.3 \\
\hline
\end{tabular}

In figure 32 the quartz-magnetite fractionations reported by James and Clayton (44) for the metamorphosed iron formations of the Lake Superior region are plotted on the quartz-magnetite curve obtained by 0 'Neil and clayton (60). (The apparent stability ranges of the Index 
Quartz-magnetite fractionations reported by James and Clayton (44) from metamorphosed iron formations plotted on the quartz-magnetite curve obtained by 0 'Neil and Clayton (60). The stability fields of various minerals shown at the base of the figure were transposed from figure 25 for purposes of comparison. 


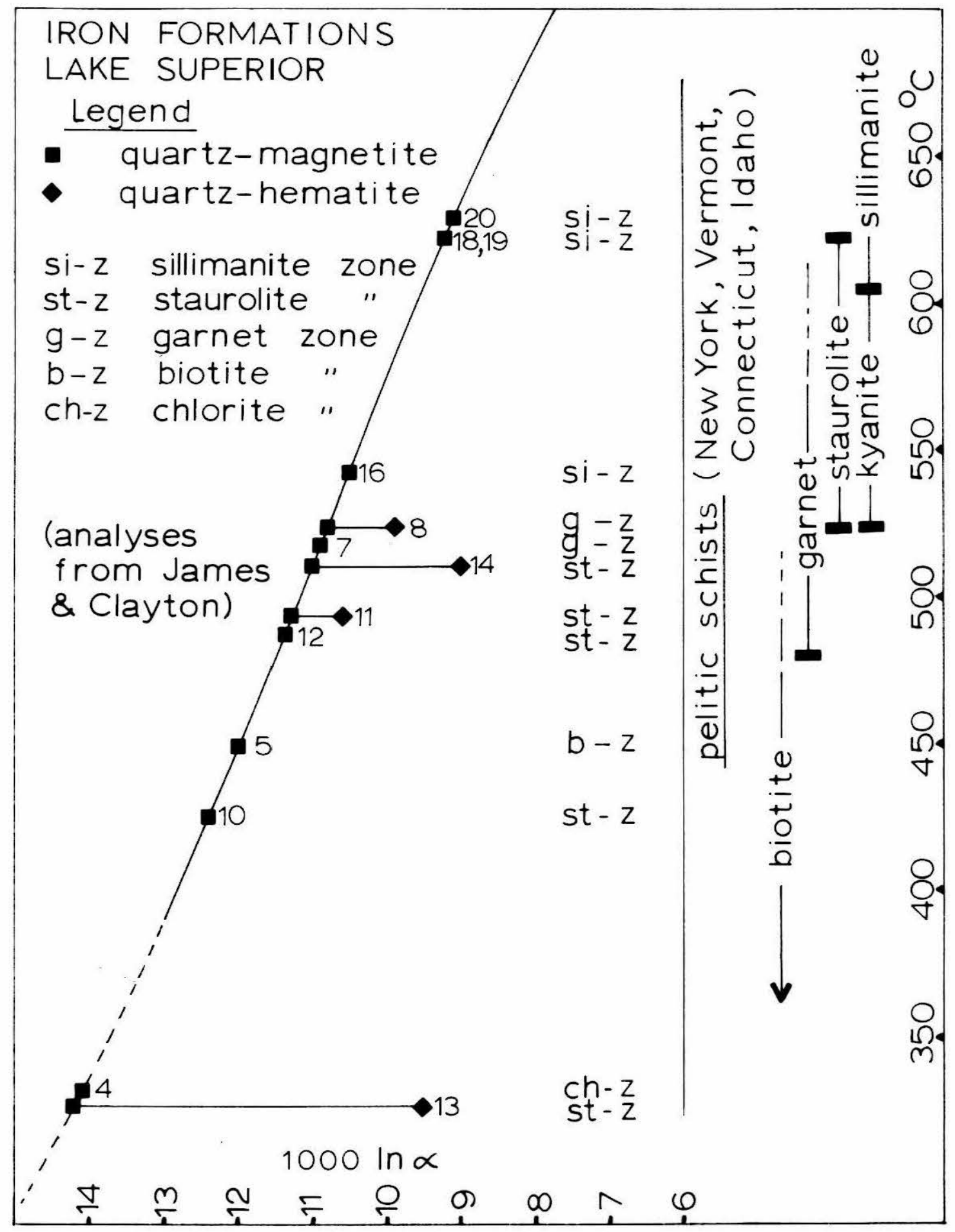


minerals shown at the base of figure 32 were transposed from figure 25 in order to permit comparison with the data obtained from pelitic schists.) Those fractionations which are much larger than expected are attributed to retrogradation. As an example, the quartz-magnetite fractionation in sample 13 from the staurolite zone is 14.2 permil, whereas the fractionations in samples 5, 8, and 14 from the biotite, gamet, and staurolite zones are 12.0, 10.8, and 11.0 permil, respectively. Sample 13 is therefore considered to be the anomalous rock. Why the fractionations in the iron formations should have increased during retrogradation, whereas the quartz-magnetite and quartzilmenite fractionations in pelitic schists appear to have decreased, is not understood. Perhaps the former phenomenon results from retrograde isotopic re-equilibration, whereas the latter phenomenon may be the result of inhomogeneous exchange with migrating pore-fluids. If equilibrium fractionation factors increase monotonically with decreasing temperature, re-equilibration post-dating the thermal maxima can only result in larger fractionations. But, if only one member of a mineral pair undergoes exchange with a medium not in equilibrium with the second member, the fractionations may either increase or decrease.

The type of plot shown in figures 33 and 34 may prove useful in determining which minerals experienced isotopic alteration during retrogradation. Consider, for example, the point in figure 33 representing the retrograded rock, EV2O. The quartz-ilmenite fractionation in this rock is smaller than expected, and may be due to $0^{18}$ enrichment of the ilmenite or $0^{16}$ enrichment of the quartz. The $\delta$ values of quartz and 


\section{FIGURE 33}

Comparison of isotopic compositions of quartz and ilmenite from non-retrograded and retrograded rocks

FIGURE 34

Isotopic analyses of all quartz-garnet and quartz-biotite pairs 


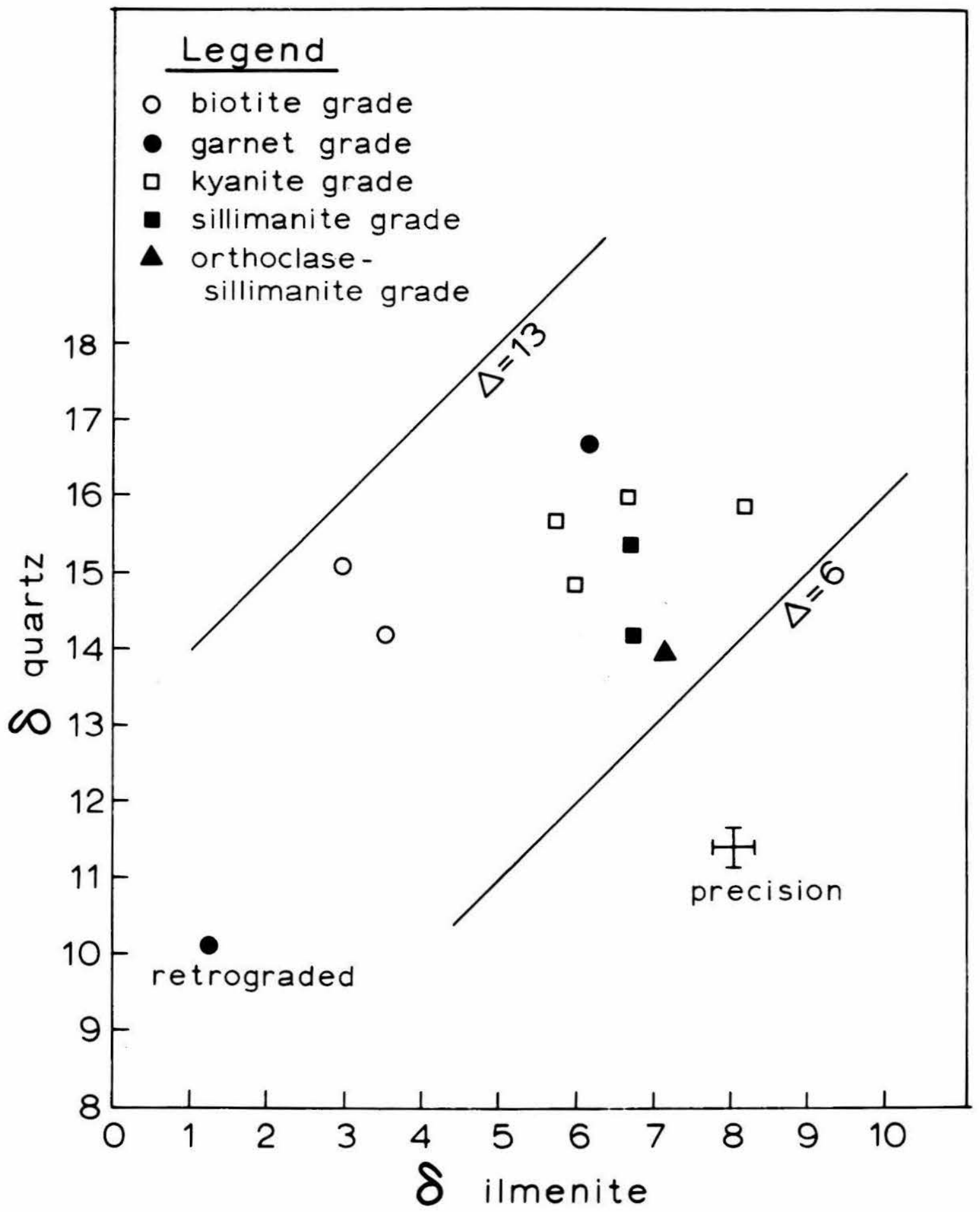

Figure 33 
$-163-$
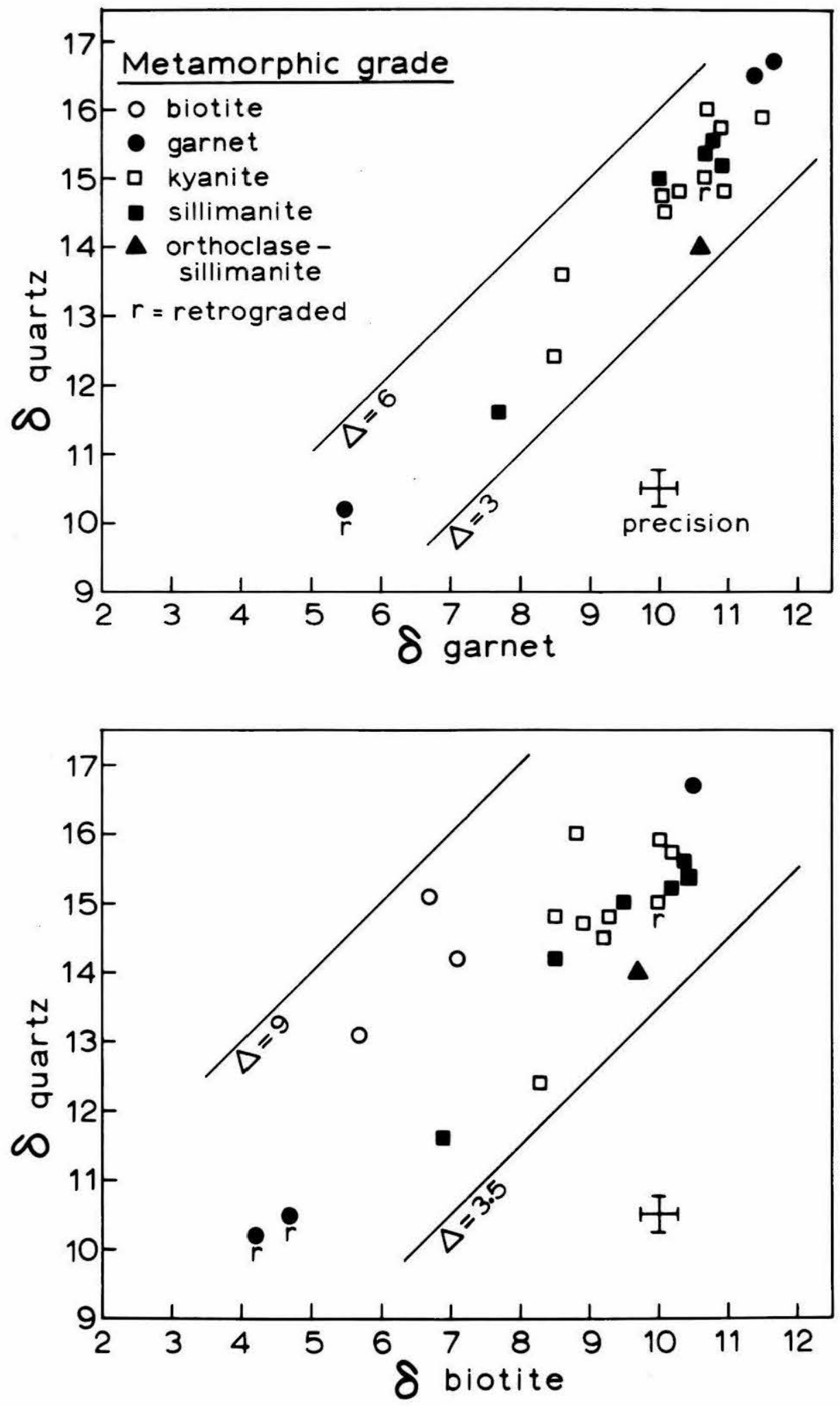

Figure 34 
ilmenite in EV2O are probably smaller than those in surrounding schists. Therefore, interlithic exchange during retrogradation could account for $0^{18}$ enrichment of the ilmenite but not $0^{16}$ enrichment of the quartz. The implication is that the ilmenite experienced greater exchange than the quartz. However, this conclusion is tentative because detailed work has not been done in the vicinity of EV2O.

\subsection{Pressures during metamorphism}

An estimate of the total rock pressure prevailing in Dutchess County at the time of metamorphism may be obtained by comparing the 1sotopic temperatures of D18 and D6 with the experimental stability fields of kyanite and sillimanite. The assumptions involved are that the kyanite and sillimanite crystallized as stable phases and that the isotopic temperatures are approximately correct.

The phase diagram for $\mathrm{Al}_{2} \mathrm{SIO}_{5}$ has recently been investigated by Bell (6) and by Khitarov, Pugin, Chao, and Slutskii (49). Seeded reactions in both directions across the phase boundaries were achieved by Bell. The phase boundaries reported by Khitarov et al. are reproduced in figure 35. They are compatible with all but one of Bell's data points established by reversed reactions. The exception is the conversion of andalusite to sillimanite 10 degrees within the stability field of andalusite assumed by Khitarov et al.

Ignoring the improbable circumstance that D6 crystallized at a much lower pressure than D18, the indicated pressure of metamorphism is 11 or 12 kilobars, corresponding to a lithostatic load of over 40 kilometers. Selsmically measured crustal thickness in the western 


\section{FIGURE 35}

Pressure-temperature diagram showing:

1. Experimental stability fields of

andalusite, kyanite, sillimanite

pyrophyllite

muscovite and quartz

and granite
[Khitarov et a.]. (49)];

[Kennedy (48)];

[Segnit and Kennedy (69)];

[Tuttle and Bowen (82)].

2. Indicated temperatures and pressures of formation of rocks D18, D6, and D12 from Dutchess County.

3. Calculated envelope of possible steady-state geotherms and a possible geotherm during the metamorphism in Dutchess County. 
- 166 -

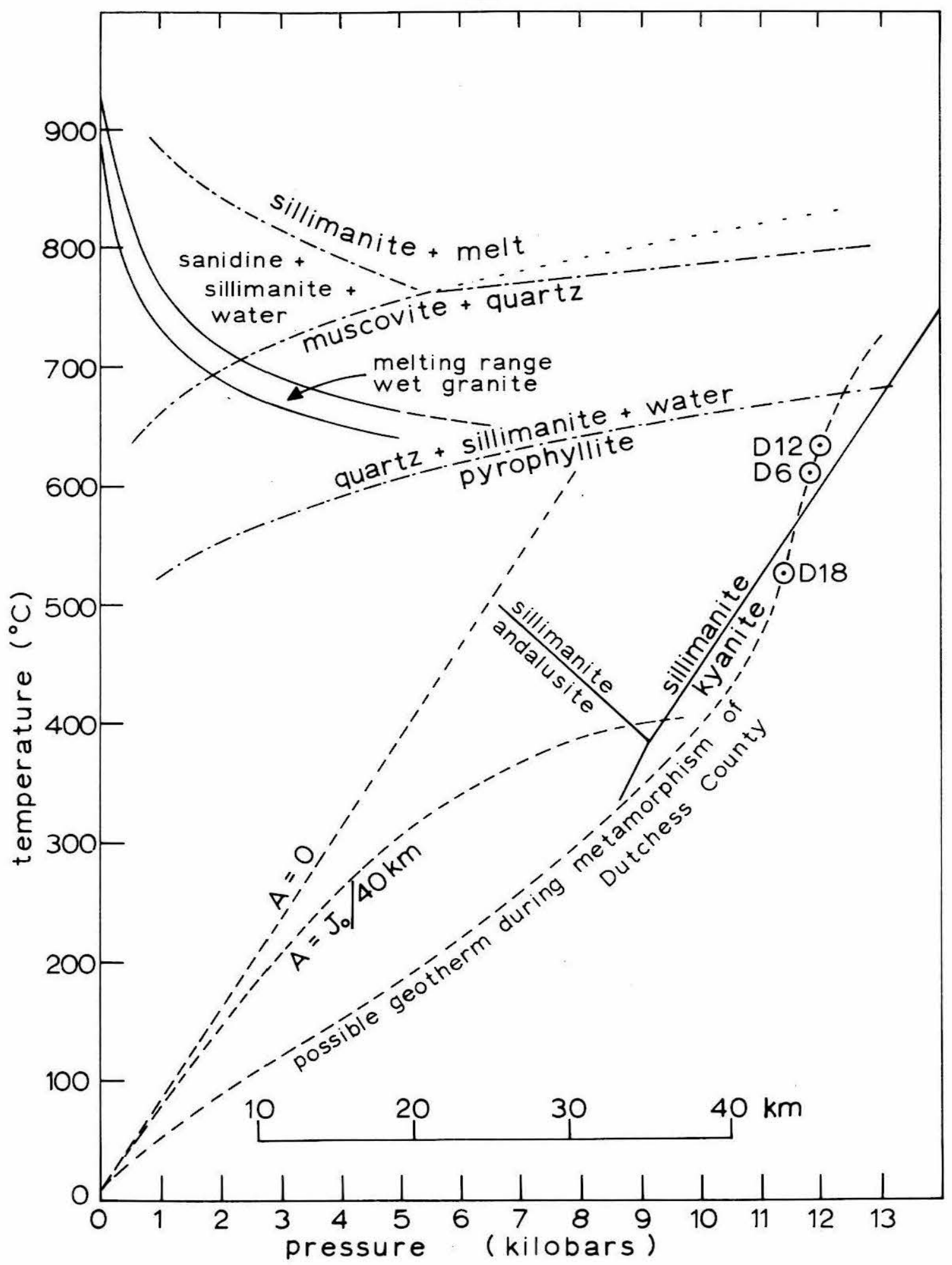

Figure 35 
United States varies from $20 \mathrm{~km}$ under the Central Valley of California to about $60 \mathrm{~km}$ under the Rocky Mountains [Pakiser (62)]. Thus, if the kyanite crystallized as a stable phase and if the isotopic temperatures are approximately correct, the metamorphism must have taken place under pressures comparable to those at the base of the normal continental crust.

\subsection{Geothermal gradients during metamorphism}

The steady-state variation of temperature (T) in the earth's crust is given by

$$
T=\frac{A}{2 K} Z^{2}+\frac{J_{0}}{K} z+T_{Z=0}
$$

where

$$
\begin{aligned}
& A=\text { rate of heat production per unit volume } \\
& K=\text { thermal conductivity } \\
& J_{0}=\text { heat flux at surface } \\
& Z=\text { depth } \\
& \text { (A and } K \text { are assumed to be constant) }
\end{aligned}
$$

On the basis of measurements reported by Birch (8) and Lee (50), values of $6 \times 10^{-3} \mathrm{cal} / \mathrm{cm} \mathrm{sec}$ deg and $1.2 \times 10^{-6} \mathrm{cal} / \mathrm{cm}^{2} \mathrm{sec}$ are assigned to $\mathrm{K}$ and $J_{0}$, respectively. The two steady-state temperature distributions plotted as dashed lines in flgure 35 were obtained by assigning values of 0 and $J_{0} / 40 \mathrm{~km}\left(\approx 10^{-5} \mathrm{cal} / \mathrm{cm}^{3} \mathrm{yr}\right)$ to $\mathrm{A}$. It is improbable that the value of A would lie outside these limits, so the two dashed lines may be considered as defining an envelope of possible steady-state geotherms. 
Assuming that D18 and D12 formed in the stability fields of kyanite and sillimanite, respectively, it is seen that the isotopic temperatures of $D 18$ and $D 6$ fall within the envelope of calculated geotherms. However, it is difficult to construct a plausible geotherm passing through $D 18$ and $D 6$ which remains within the envelope. Mechanisms which may be invoked to reconcile the data include:

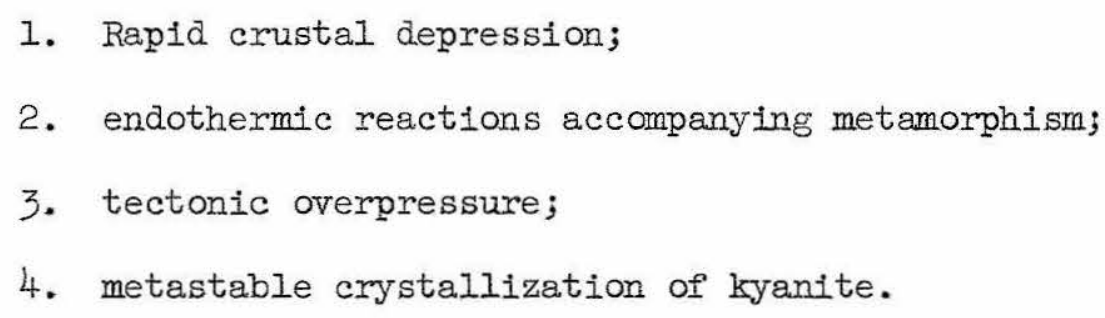

An altermative solution, taking horizontal temperature gradients into account, is illustrated in figure 36. Geotherms are shown before and after perturbation by a local heat source at depth. The three geotherms passing through D22, D18, and D12 represent the maximum temperatures reached at these three localities, but may not coincide in time. Since $D 18$ and $D 12$ are separated by $10 \mathrm{~km}$ and appear to have crystallized at temperatures differing by $100^{\circ} \mathrm{C}$, horizontal temperature gradients of about $10^{\circ} \mathrm{C}$ per $\mathrm{km}$ are implied by this model. If the maximum temperatures at $D 18$ and $D 12$ were not synchronous, larger gradients would be required. However, these gradients are probably smaller than the vertical gradient of $50^{\circ} \mathrm{C}$ per $\mathrm{km}$ assumed in the previous model for the Dutchess County geotherm shown in figure 35.

All geotherms must pass from the andalusite or sillimanite fields into the kyanite field with increasing depth, yet the transition 
Hypothetical model showing perturbed and unperturbed geotherms relative to the stability fields of pyrophyllite, kyanite, and sillimanite. D22, D18, and D12 represent temperatures derived Irom isotopic analyses on Dutchess County rocks from the garnet, kyanite, and sillimanite zones, respectively. The geotherms, in P-T-X space, are projected onto the P-T plane. ( $\mathrm{X}=$ horizontal distance.) 

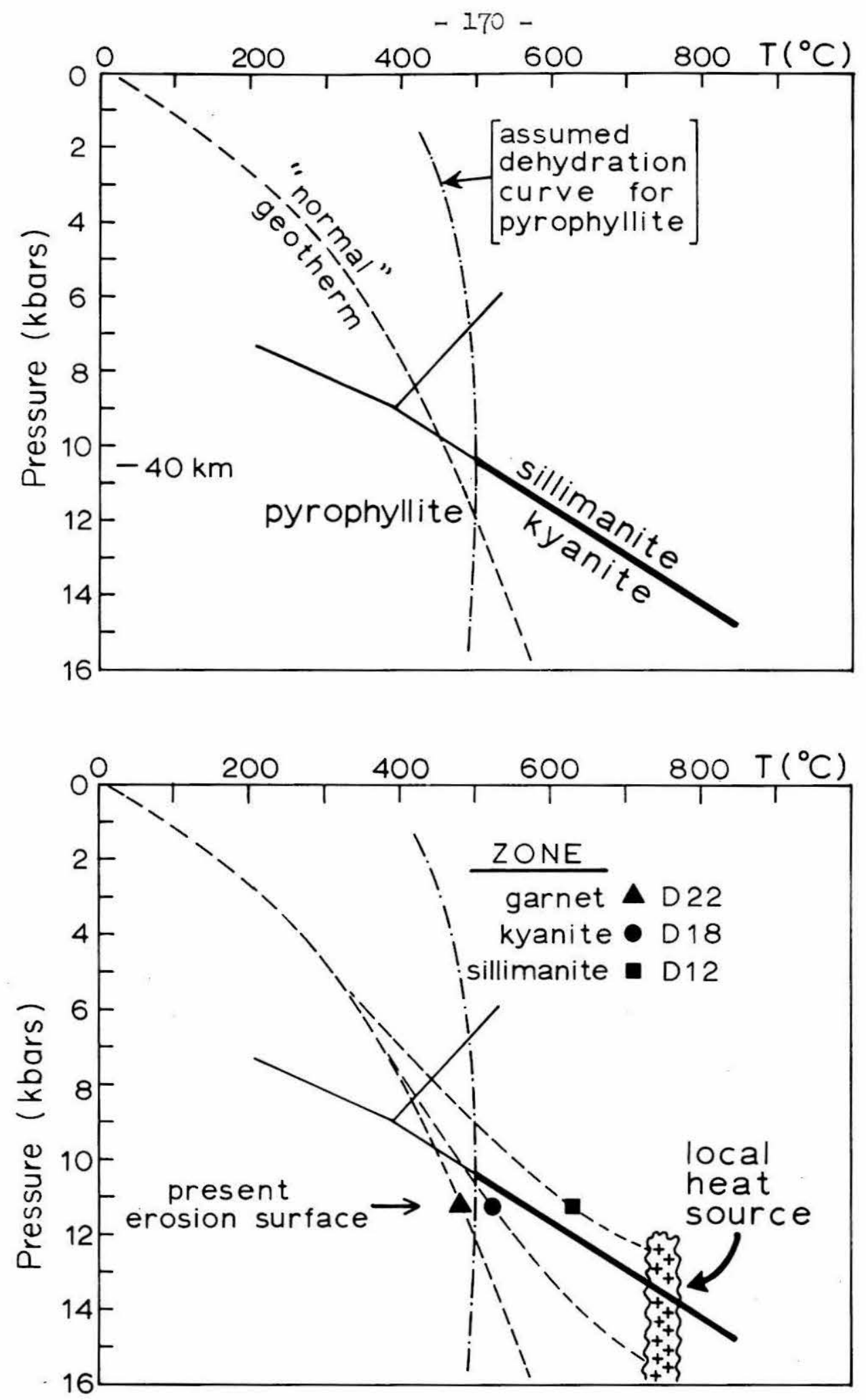

Figure 36 
of sillimanite or andalusite to kyanite with increasing metamorphism is seldom observed. As pointed out by Thompson (77), the paucity of evidence for these transitions suggests that pyrophyllite is usually stable along the geotherm until the kyanite field is entered. The transition of kyanite to sillimanite with progressive metamorphism, observed in many terrains, requires a perturbation of the normal geotherm. In fact, sillimanite zones are often spatially associated with plutonic igneous rocks, as is the case in northern Idaho.

In summary, the isotopic temperatures can be reconciled with the geothermal data and the experimental stability fields of kyanite and sillimanite.

\subsection{Comparison of isotopic with other estimates of temperature}

\section{a. Mineral parageneses}

The equilibrium mineral assemblage in any system is determined by the variables $X_{1}, P$, and $T$, where $X_{j}$ is the mole fraction of component $j$. In principle, one can reproduce the same values of $x_{i}$ in the laboratory, and ascertain the petrogenetic grid in P-T space for that system. Unfortunately, certain critical components are highly mobile, and their concentrations in a rock during metamorphism can vary with time. Water and carbon dioxide are the two most important such constituents. With the exception of the kyanite-sillimanite transition, all the isograds mentioned in this thesis are determined by reactions involving water. Therefore, the isotopically determined temperatures 
cannot be directly compared with the experimental petrogenetic grid obtained from hydrothermal studies.

In order to evaluate the compatibility of the isotopic temperatures with the experimental stability fields of various mineral assemblages, the activity of water during metamorphism must be considered. As an example, the experimental decomposition curve for pure pyrophyllite in the presence of water, as reported by Kennedy (48), is shown in figure 35. The reaction is:

$$
\begin{aligned}
& \mathrm{Al}_{2} \mathrm{Si}_{4} \mathrm{O}_{10}(\mathrm{OH})_{2}=\mathrm{Al}_{2} \mathrm{SiO}_{5}+3 \mathrm{SiO}_{2}+\mathrm{H}_{2} \mathrm{O} . \\
& \text { pyrophyllite = kyanite }+3 \text { quartz + water }
\end{aligned}
$$

Assuming the isotopically determined temperatures to be correct, the occurrence of kyanite near D18 demands that the experimental equilibrium for the above reaction be shifted by at least $150^{\circ} \mathrm{C}$ to a lower temperature. This in turn requires that the activity of water be less than that prevailing during the experimental runs, because quartz and kyanite occur as essentially pure phases.

The variation in Gibbs free energy of reaction $(\Delta F)$ with temperature (T) and the activity of water (a) is given by

$$
(\mathrm{d} \Delta \mathrm{F})_{\mathrm{P}}=-\Delta \mathrm{S} d \mathrm{~T}+\mathrm{R} \ln \mathrm{a} \mathrm{dT}+\mathrm{RT} \mathrm{d} \ln \mathrm{a} \text {, }
$$

where $\triangle S$ is the molar entropy of reaction when $a=1$. Setting $d \Delta F=$ 0, we obtain

$$
\text { dIna }_{\Delta \mathrm{In} T}=\frac{\Delta S}{\mathrm{R}}-\ln \mathrm{a} \text {. }
$$


The solution to this equation is given by

$$
\text { In } \mathrm{a}=\frac{\Delta \mathrm{S}}{\mathrm{R}}-\frac{\mathrm{C}}{\mathrm{T}} \text {, }
$$

where $C$ is a constant.

Assuming $a \approx I$ at $T=948^{\circ} \mathrm{K}\left(675^{\circ} \mathrm{C}\right)$, and assigning a value of $10 \mathrm{cal} / \mathrm{deg}$ mole to $\Delta S$ [based on the estimates of Thompson (77) and Fyfe and Verhoogen (32)], we find that the isotopic temperature of D18 and the hydrothermal studies can be reconciled if the activity of water prevailing during the metamorphism of DI8 were less than 0.4 . However, it should be remembered that the above arguments collapse if the kyanite crystallized as a metastable phase at a much lower pressure than indicated in figure 35 .

The hydrothermal experiments permit a temperature estimate for one of the rocks in this study. $\mathrm{A} 64 \mathrm{~g}$ was collected from the sillimaniteorthoclase zone in an area of abundant pegmatites and migmatites. It appears that the temperature of formation of this rock was a little below that required to partially melt the rocks and a little above the stability range of muscovite [Lundgren (55)]. Experimental curves representing the melting of granite and the dehydration of muscovite in the presence of quartz and water are shown in figure 35. It is clear that if A64g crystallized at a pressure greater than 2 kbars the activity of water must have been lower than the activities employed in the hydrothermal studies. As the activity of water decreases, the melting curve of granite moves to higher temperatures and the dehydration curve of muscovite moves to lower temperatures. The two curves should 
coincide at some temperature between $650^{\circ} \mathrm{C}$ and $750^{\circ} \mathrm{C}$. Since $A 64 \mathrm{~g}$ formed under conditions close to the melting temperature of granite and the dehydration temperature of muscovite, the indicated temperature of formation is $700^{\circ} \mathrm{C} \pm 50^{\circ} \mathrm{C}$. The isotopically determined temperature for $\mathrm{A} 64 \mathrm{~g}$, based on the quartz-ilmenite fractionation and the assumption that the quartz-magnetite fractionation would be $9 \%$ larger, is also approximately $700^{\circ} \mathrm{C}$. This agreement, approximate though it may be, increases our confidence in the quartz-ilmenite curve shown in figure 25 .

Winkler (87) investigated the effects of heating common limefree clays in the presence of water at 2 kbars in the temperature range of 400 to 750 degrees Centigrade. Three slightly different starting materials were used. Plotted in Pigure 37 are the minimum temperatures at which pyrophyllite, biotite, sillimanite-mullite solid solution, cordierite, and $\mathrm{K}$-feldspar were produced. At $700-720^{\circ} \mathrm{C}$, the charges yielded anatectic melts having compositions resembling those of leucogranites.

Also plotted in figure 37 are the reaction temperatures derived from the isotopic data shown in figure 25. The temperatures are plotted on the experimental kyanite-sillimanite transition curve, because both these minerals are common in the metamorphic rocks of this study. The latitude available in choosing the activity of water permits us to reconcile the isotopic temperatures with the hydrothermal studies, but reconciliation would be less awkward had biotite appeared at lower tem- 
$-175-$

FIGURE 37

Comparison of the experimental reaction temperatures of Winkler (87) with those inferred from the isotopic quartz-magnetite and quartzilmenite fractionations. 


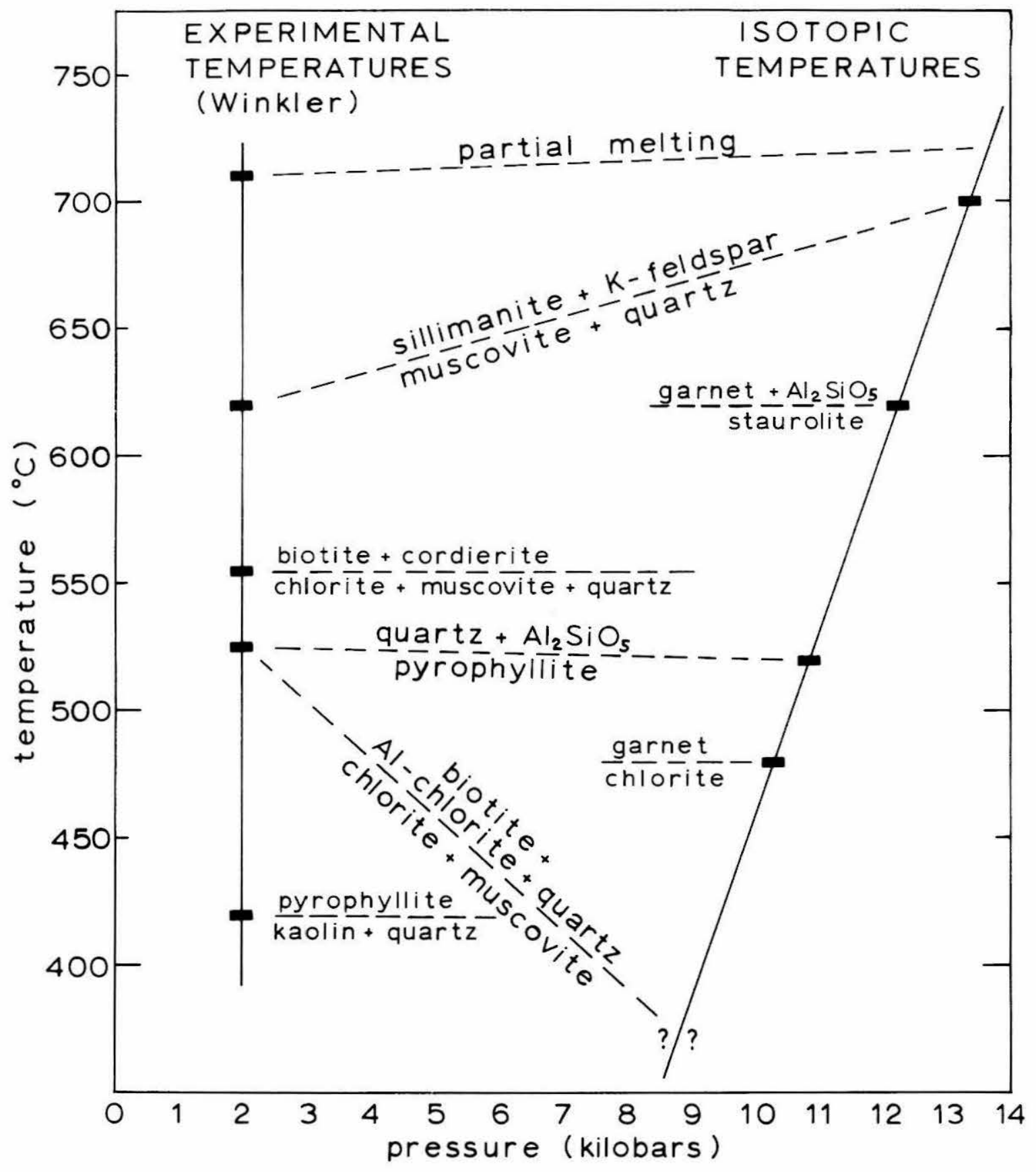

Figure 37 


$$
-177-
$$

peratures and muscovite decomposed at higher temperatures in Winkler's experiments.

The temperature of $620^{\circ} \mathrm{C}$ determined by Winkler for the breakdown of muscovite in the presence of quartz and water at two kbars is in conflict with the findings of Segnit and Kennedy (69), who found the breakdown temperature to be about $700^{\circ} \mathrm{C}$ in the presence of water at two kbars. The low dehydration temperature found by Winkler may possibly be due to a low activity of water resulting from the solution of various silicates not present in the experiments of Segnit and Kennedy. The non-appearance of biotite in Winkler's experiments at temperatures below $525^{\circ} \mathrm{C}$ is presumably due to the unfavorable bulk-chemistry of his charges, which were high in alumina. In the field, biotite usually appears at much lower grades than kyanite.

\section{b. Compositions of solid solutions}

Because the saturation limits of solid solutions are temperature dependent, chemical analyses of minerals which are members of isomorphous series can yield information on their temperatures of formation.

\section{(1) Calcite-dolomite}

The solubility of $\mathrm{MgCO}_{3}$ in $\mathrm{CaCO}_{3}$ as a function of temperature has been determined by Graf and Goldsmith (34). In the temperature range $500^{\circ} \mathrm{C}$ to $600^{\circ} \mathrm{C}$, the mole fraction of $\mathrm{MgCO}_{3}$ in $\mathrm{CaCO}_{3}$ increases by 1 percent for every $40^{\circ} \mathrm{C}$ rise in temperature. Goldsmith and Heard (35) state that the solubility increases to the extent of approximately 1 percent per 5 kbars total pressure. 
Engel and Engel (24) have used the composition of calcite containing exsolved dolomite blebs to obtain an estimate of $500^{\circ} \mathrm{C}$ for the minimum temperature of metamorphism in the Emerybille area, Adirondack Mountains, New York. No pressure correction was applied, so this estimate may be high.

$0^{18} / 0^{16}$ values for quartz and magnetite from a paragneiss from Emeryville are also given by Engel and Engel. The fractionation is 11.1 permil, which indicates a temperature of approximately $500^{\circ} \mathrm{C}$. The isotopic temperature is thus compatible with the estimate based upon the magnesium content of calcite. (These authors also report a quartzmagnetite fractionation of 8.2 permil for paragneiss from a zone of more intense metamorphism a few kilometers from the perimeter of the Adirondack Igneous Massif. This fractionation indicates a temperature of $680^{\circ} \mathrm{C}$.)

\section{(2) Muscovite-paragonite}

An estimate of the temperature of formation of rock IAIOp is provided by comparison of the composition of calcium-free muscovite (accompanying paragonite) with the experimentally-derived solvus of Eugster and Yoder (30). The basal spacing of muscovite in LAlOp, as determined by Albee (I), is $9.960 \AA$, indicating a temperature of about $550^{\circ} \mathrm{C}$. The effect of pressure on this determination is not known precisely, but Albee estimates that a $10 \mathrm{kbar}$ pressure difference would not change the indicated temperature of formation by more than $50^{\circ} \mathrm{C}$. 


$$
\text { - } 179 \text { - }
$$

The isotopic quartz-magnetite and quartz-1]menite fractionations indicate that the temperature of formation of LA168, IA33, and IAIOp was approximately $560^{\circ} \mathrm{C}$, in good agreement with the estimate based on the paragonite content of muscovite. 


\section{SUMMARY AID CONCLUSIONS}

Regularities in the relative $0^{18} / 0^{16}$ ratios of coexisting quartz, garmet, ilmenite, and magnetite in regionally metamorphosed rocks from New York, Vermont, Connecticut, and Idaho suggest that these minerals crystallized in isotopic equilibrium. The regularity is illustrated by the following example, in which fractionations between two pairs of minerals are compared in order to reduce temperaturedependent variability: The average value of the ratio ( $\delta_{\text {garmet }}{ }^{-}$ $\left.\delta_{1 \text { imenite }}\right) /\left(\delta_{\text {quartz }}-\delta_{\text {ilmenite }}\right)$, obtained from the 8 rocks in which these minerals were analyzed, is 0.52 , and the average deviation from this value is 0.025 . This varlation is within the limits of analytical precision. The 8 rocks represent the garnet, kyanite, sillimanite, and orthoclase-sillimanite zones of metamorphism.

Quartz-magnetite and quartz-ilmenite fractionations, with few exceptions, are found to decrease with increasing metamorphic grade. The exceptions are, in most cases, rocks which have experienced mineralogical retrogradation, such as chloritization of garmet, or have experienced more than one episode of metamorphism.

The experimental quartz-magnetite fractionations of $0^{i} \mathrm{Ne} i 1$ and Clayton (60) are employed in obtaining estimates of temperature during metamorphism. Regionally metamorphosed pelitic schists containing kyanite and staurolite, or kyanite and chloritold, appear to have crystallized at $520^{\circ} \mathrm{C}$ to $600^{\circ} \mathrm{C}$. These temperatures are compatible with the experimentally derived stability fields of various mineral assemblages, 
providing the activity of water during metamorphism was considerably less than unity. A temperature estimate based on the paragonitecontent of muscovite is available for one of the rocks studied [Albee (1)]. It is in good agreement with the temperature obtained from isotopic data.

Quartz-ilmenite fractionations vary from 12.1 permil in the biotite zone to 6.8 permil in the sillimanite-orthoclase zone. The correlation of quartz-ilmenite fractionations with metamorphic grade indicates that this pair of minerals is of potential value as an isotopic geothermometer, but it has not been calibrated in the laboratory. An attempt was therefore made to relate quartz-1lmenite with quartzmagnetite fractionations. Comparisons at two localities yielded quartzilmenite fractionations of 8.7 permil and 9.3 permil associated with quartz-magnetite fractionations of 9.4 and 10.2 permil, respectively. Fractionations among quartz, muscovite, and biotite are internally consistent, as are those among quartz, garnet, and ilmenite. However, the fractionations involving biotite or muscovite do not reflect metamorphic grade as accurately as do fractionations among the anhydrous minerals analyzed. These observations are interpreted to mean that muscovite and biotite undergo isotopic re-equilibration during retrogradation, whereas quartz, garnet, ilmenite, and magnetite are not appreciably exchanged. This explanation gains some support from a study of the partial isotopic exchange between a xenolith of schist and intrusive trondjemite. Quartz and garmet in the xenolith have suffered less exchange than muscovite and biotite. 
A tendency towards the local homogenization of isotopic compositions of particular minerals among various metamorphic rocks is noted. In some areas, there is evidence of a general decrease in $0^{18} / 0^{16}$ ratios accompanying homogenization. It appears that the metasedimentary rocks were, to varying extents, in isotopic communication with one another and with plutonic rocks. Homogenization is attributed to exchange with migrating pore-fluids, but more work is required before the details of the process can be known. This type of information may be of significance in determining the degree to which the chemical potentials of volatile components during metamorphism are controlled by regional factors. 


\section{BIBLIOGRAPHY}

1. Albee, A. L., Phase equilibria in three assemblages of kyanitezone pelitic schists; in press, 1964.

2. Baertschi, P. and Schwander, H., Ein neues Veriahren zur Messung der Unterschiedene im 0l8-Gehalt von Silikatgesteinen; Helv. Chim. Acta 35, 73, 1957.

3. Baertschi, P. and Silverman, S. R., The determination of the relative abundance of the oxygen isotopes in silicate rocks; Geochim. et Cosmochim. Acta I, 317, 1951.

4. Balk, R., Structural and petrological studies in Dutchess County, New York; Bull. Geol. Soc. Am. 47, 5, 1936.

5. Barth, T. F. W., Structural and petrologic studies in Dutchess County, New York; Bul1. Geol. Soc. Am. 47, 6, 1936.

6. Bell, P. M., Aluminum silicate system: Experimental determination of the triple point. Science, 139, No. 3539, 1055-1056.

7. Bigelelsen, J. and Mayer, M. G., Calculation of equilibrium constants for isotopic exchange reactions; J. Chem. Phys. 15, 261, 1947.

8. Birch, F. et a.l., Handbook of physical constants; Geol. Soc. Am. Spec. Paper 36, 1942.

9. Bottinga, J., Oxygen isotopes in geology; Master's Thesis, Univ. of Brit. Col., 1963.

10. Bowen, N. I., The mineralogical phase rule; Wash. Acad. Sci. Jour., 15, 1925.

11. Cady, W. M. et al., Bedrock geology of the Lincoln Mountain Quadrangle, Vermont; U.S. Geol. Survey, Quadrangle Map GQ-164, 1962 .

12. Carroll, G. V. Dover Plains, New York-Connecticut, quadrangle, unpub. map, 1949.

13. Clark, S. P., A redetermination of equilibrium relations between kyanite and sillimanite; Am. Jour. Sc1., 259, p. 641-650, 1961.

14. Clayton, R. N. and Epstein, S., The relationships between $0^{18} / 0^{16}$ ratios in coexisting quartz carbonate and iron oxides from various geologic deposits; J. Geol. 66, 352, 1958. 
15. Clayton, R. N., and Epstein, S., The use of oxygen isotopes in high-temperature geological thermometry; J. Geol. 69, 447, 1961.

16. Clayton, R. N., and Mayeda, T. D., The use of bromine pentafluoride in the extraction of oxygen from oxides and silicates for isotopic analysis; Geochim. et Cosmochim. Acta 27, 43, 1963.

17. Collins, G. E., The bedrock geology of the Ellington quadrangle, Connecticut; Connecticut Geol. and Nat. History Survey Quadrangle Rept. 4, 1954.

18. Compston, W. and Epstein, S., A method for the preparation of carbon dioxide from water vapour for oxygen isotope analysis; Trans. Am. Geoph. Union 39, 511, 1958.

19. Craig, H., Isotopic standards for carbon and oxygen and the correction factors for mass spectrometric analysis of carbon dioxide; Geochim. et Cosmochim. Acta 12, 133, 1957.

20. Craig, H., Standards for reporting concentrations of deuterium and oxygen 018 in natural water; Science 133, 1833, 1961.

21. Crowley, M. S, , and Roy, R., The effect of formation pressures on sheet structures-a possible case of Al-Si ordering; Geochim. et Cosmochim. Acta 18, 94, 1960.

22. Doll, C. G., et al. Centennial geologic map of Vermont; Vermont geological survey, 1961.

23. Dontsova, E. I., Method of determining oxygen isotope ratios in rocks and minerals; Geochemistry, p. 824, 1959.

24. Engel, A. E. J., and Engel, C., Progressive metamorphism and granitization of the major paragneiss, northwest Adirondack; Bull. Geol. Soc. Am. 69, 1369, 1958.

25. Engel, A. E. J., and Engel, C., Progressive metamorphism of amphibolite, northwest Adirondack Mountains, New York; Geol. Soc. Am., Buddington volume, p. 37, 1962.

26. Engel, A. E. G., Clayton, R. N., and Epstein, S., Variations in isotopic composition of oxygen and carbon in Leadville limestone (Mississippian, Colorado) and its hydrothermal metamorphic phases; J. Geol. 66, 374, 1958.

27. Epstein, S., Buchsbaum, R., Lowenstam, H. A., and Urey, H. C., Carbonate-water temperature scale; Bull. Geol. Soc. Am. 62, 417, 1951. 
28. Epstein, S., Urey, H. C., Lowenstam, H. A., and McKinney, C. R., Measurement of paleotemperatures and temperatures of the upper Cretaceous of England, Denmark, and southeasterm U.S.; Bull. Geol. Soc. Am. 62, 399, 1951.

29. Eskola, P., The mineral facies of rocks; Norsk. Geol. Tiasskr., vol. $6, \mathrm{p} .143,1920$.

30. Eugster, H. P., and Yoder, H. S., Annual report of the director of the geophysical laboratory; Carnegie Institution of Washington Yearbook, No. 54, 124, 1955.

31. Fawcet, J. J., and Yoder, H. S. Jr., Quartz-chlorite assemblages in the system $\mathrm{MgO}-\mathrm{Al}_{2} \mathrm{O}_{3}-\mathrm{SiO}_{2}-\mathrm{H}_{2}$; Annual report of the director of the geophysical laboratory, Carnegie Institution of Washington Yearbook, 61, p. 88, 1962 .

32. Fyfe, W. S., and Verhoogen, J., Metamorphic reactions and metamorphic facies; Geol. Soc. Am., Memoir 73, 1958.

33. Graf, D. L., and Goldsmith, J. R., Dolomite-magnesian calcite relations at elevated temperatures and $\mathrm{CO}_{2}$ pressures; Geochim. et Cosmochim. Acta 1, Nos. 3 and 4, 109, 1955.

34. The solid solubility of $\mathrm{MgCO}_{3}$ in $\mathrm{CaCO}_{3}$, a revision; Geochim. et Cosmochim. Acta 13, 218, 1958.

35. Goldsmith, J. R., and Heard, H. C., Subsolidus phase relations in the system $\mathrm{CaCO}_{3}-\mathrm{MgCO}_{3}$; Jour. Geology, 69, No. 1, 45, 1961.

36. Haul, R., and Dltmbgen, G., Untersuchung der Sauerstoffbeweglichkeit in Titandioxyd, Quarz und Quarzglas mit Hilfe des hetergenen Isotopenaustausches; Zeitschift fur Elcktrochemie, 1962.

37. Hietanen, A., Anorthosite and associated rocks in the Boehls Butte Quadrangle and Vicinity, Idaho; U.S.G.S. Prof. Paper 344-B, 1963.

38. , Metamorphic facies and style of folding in the Belt Series northwest of the Idaho batholith; Extrait des Comptes Rendus de la Societe geoloique de Finlande N:0 XXXIII, 1961.

39. Relation between deformation, metamorphism, metasomatism, and intrusion along the northwest border zone of the Idaho batholith, Idaho; U.S.G.S. Prof. Paper 424, 1961.

40. , Kyanite, andalusite, and sillimanite in the schist in Boehls Butte quadrangle, Idaho; Am. Mineralogist, v. 4I, p. 1-27, 1956. 
41. Hoekstra, H. R. and Katz, J. J., Direct determination of oxygen in less familiar oxides; Anal. Chem. 25, 1608, 1953.

42. Hoering, T. C., The physical chemistry of isotopic substances; Ann. report of the Director of the Geophysical laboratory, p. 201, 1960-1961.

43. Hutchinson, D. A., Isotopic exchange of oxygen in the systems water-silica and oxygen-silica; J. Chem. Phys., 22, 758, 1954.

44. James, H. I. and Clayton, R. N., Oxygen isotope fractionation in metamorphosed iron formations of the Lake Superior region and in other iron-rich rocks; Geol. Soc. Am. Buddington Volume, p. 217, 1962 .

45. Jost, W., Diffusion in solids, liquids and gases; Academic Press Inc., New York, 1960.

46. Joy, H. W. and Libby, W. F., Size effects among isotopic molecules; J. Chem. Phys. 33, 1276, 1960.

47. Kennedy, G., The pressure, volume-temperature relations of $\mathrm{H}_{2} \mathrm{O}$ at elevated temperature and pressure; Am. Jour. Sci., v. 248, p. 540 .

48. Kennedy, G., Phase relations in the system $\mathrm{Al}_{2} \mathrm{O}_{3}-\mathrm{SiO}_{2}-\mathrm{H}_{2} \mathrm{O}$ at high tempera.tures and pressures; Amer. Jour. of Sci., 257, 563, 1959.

49. Khitarov, N. I., Pugin, V. A., Pin, Chao, and Slutskii, A. B., Relation between andalusite, kyanite, and sillimanite at moderate temperatures and pressures; Geochemistry (translation of Geochimga, 3, 235, 1963).

50. Lee, W. H. K., Heat flow data analysis; Rev. Geophys, , 1, 449, 1963.

51. Line, W. R. and Aradine, P. W. Ind. Eng. Chem. Anal. Ed., 2, 60, 1937.

52. Long, D. E., Isotopic ages from northern New Jersey and southeasterm New York; Bull. Geol. Soc. Am. 73, No. 8, 997, 1962.

53. Lowenstam, H. A., Mineralogy, $0^{18} / 0^{16}$ ratios, and strontium and magnesium contents of recent and fossil brachiopods and their bearing on the history of the oceans; J. Geol. 69, 241, 1961.

54. Lundgren, L. Jr., Bedrock geology of the Deep River quadrangle; Conn. Geol. Nat. History Survey Quad. Rept. 13, 1963.

55. Bedrock geology of the Essex quadrangle; Conn. Geol. Nat. History Survey Quad. Rept. 15, 1964. 
56. McKinney, C. R. et al., Improvements in mass spectrometers for the measurement of small differences in isotope abundance ratios; Rev. Sci. Instr. 21, 724, 1950.

57. Moenke, H., Mineralspektren, Deutsche Akademie Der Wissenschaften Zu Berlin Akademie-Verlag. Berlin, 1962.

58. Nier, A. O. C., A redetermination of the relative abundances of the isotopes of carbon, nitrogen, oxygen, argon and potassium; Phys. Rev. 77, 789, 1950.

59. A mass spectrometer for isotope and gas analysis; Rev. Sci. Instr. 18, 398, 1947.

60. O'Neil, J. R., and Clayton, R. N., Oxygen isotope geothermometry; in Isotopic and Cosmic Chemistry; North-Holland Publishing Company, Amsterdam, p. 157, 1964.

61. Orville, P. M., Alkali ion exchange between vapor and feldspar phases; Am. Jour. Sci. 261, 201, 1963.

62. Pakiser, I. C., Structure of the crust and upper mantle in the westerm United States; Jour. Geophys. Res., 68, No. 20, 5747, 1963.

63. Rodgers, J., Gates, R. M., Cameron, E. N. and Ross, R. J., Jr., Preliminary geological map of Connecticut, Conn. State Geol. and Nat. History Survey, 1956.

64. Rodgers, J., Gates, R. M., and Rosenfeld, J. I., Explanatory text for preliminary geological map of Connecticut; Conn. Geol. Nat. History Survey Bull. 84, 1956.

65. Rosenfeld, J. I. and Eaton, G. P., Itinerary for trip A; 50th Annual Meeting, New England intercollegiate geological field conference, 1958.

66. Roginsky, S. Z., Theoretical principles of isotope methods for investigating chemical reactions, Moscow 1956, transl. Consultants Bureau Inc., New York.

67. Sales, R. H., and Meyer, C., Results from preliminary studies of vein formation at Butte, Montana; Econ. Geology, 44, 465, 1949.

68. Schwander, H., Bestimmung des relativen SauerstoffisotopenVerhaltnisses in Silikatgesteinen und Mineralien; Geochim. et Cosmochim. Acta $\stackrel{4}{4}, 261,1953$.

69. Segnit, R. E., and Kennedy, G., Reactions and melting relations in the system muscovite-quartz at high pressures; Am. Jour. Sc1., 259, 280, 1961 . 
70. Sharma, T., Oxygen analyses of minerals, oxides, and related compounds; doctoral thesis, University of Chicago, 1963.

71. Silverman, S. R., The isotope geology of oxygen; Geochim. et Cosmochim. Acta 2, 26, 1951.

72. Taube, H., Use of oxygen isotope effects in the study of hydration of ions; J. Phys. Chem., 58, 523, 1954.

73. Taylor, H. P., $0^{18} / 0^{16}$ ratios in coexisting minerals of igneous and metamorphic rocks; $\mathrm{Ph} . \mathrm{D}$. thesis, Califormia Institute of Technology, 1959.

74. Taylor, H. P. and Epstein, S., Relationship between $0^{18} / 0^{16}$ ratios in coexisting minerals of igneous and metamorphic rocks, Part I: Principles and experimental results; Bull. Geol. Soc. Am. 73, 461, 1962.

75 . Relationship between $0^{18} / 0^{16}$ ratios in coexisting minerals of igneous and metamorphic rocks, Part 2: Applications to petrologic problems; Bull. Geol. Soc. Am. 73, 675, 1962.

76. Taylor, H. P., Albee, A. L., and Epstein, S., $0^{18} / 0^{16}$ ratios of coexisting minerals in three mineral assemblages of kyanitezone pelitic schist; Jour. Geol., 71, No. 4, 513, 1963.

77. Thompson, J. B., Jr., The thermodynamic basis for the mineral facies concept; Am. Jour. Sci. 253, 65, 1955.

78. The graphical analysis of mineral assemblages in pelitic schists; Am. Mineral., 42, 842, 1957.

79. , A gneiss dome in southeastern Vermont; Doctoral thesis, Massachusetts Institute of Technology, 1950.

80 . Southerm Vermont; Guidebook for field trips in New England, Geol. Soc. Am. sixty-fifth annual meeting, 1952.

81. Tudge, A. P., A method of analysis of oxygen isotopes in orthophosphates-its use in measurement of Paleotemperatures; Geochim. et Cosmochim. Acta 18, 81, 1960.

82. Tuttle, O. F. and Bowen, N. L., Origin of granite in the light of experimental studies in the system $\mathrm{NaAlSi}_{3} \mathrm{O}_{8}-\mathrm{SiO}_{2}-\mathrm{H}_{2} \mathrm{O}$; Geol. Soc. Am. Memoir 74, 1958.

83. Urey, H. C., The thermodynamic properties of isotopic substances; J. Chem. Soc. p. 562, 1947. 
84. Urey, H. C. and Greiff, I., Isotopic exchange equilibria; J. Am. Chem. Soc. 57, 321, 1935.

85. Urey, H. C. Lowenstam, H. A., Epstein, S., and McKinney, C. R., Measurement of Paleotemperatures of the Upper-Cretaceous of England, Denmark and the southeastern United States; Bull. Geol. Soc. Am. 62, 399, 1955.

86. Vinogradov, A. P. et al., The isotopic composition of oxygen in igneous rocks and meteorites; Geochemistry, p. 235, 1958.

87. Winkler, H. G. F., Experimentelle Gesteinmetamorphose--1: Hydrothermale Metamorphose karbonatfreier Tone, Geochim. et Cosmochim. Acta 13, 42, 1957.

88. Wyart, J. et al., Echange isotopiques des atomes d'oxygene dans les silicates; Bull. Soc. franc. Miner. Crist. IXXXII, 387, 1959.

89. Taylor, H. P. and Epstein, S., Comparison of oxygen isotope analyses of tektites, soils, and impactite glasses; in Isotopic and Cosmic Chemistry; North-Holland Publishing Company, Amsterdam, p. 181, 1964 . 
INDEX TO APPENDICES

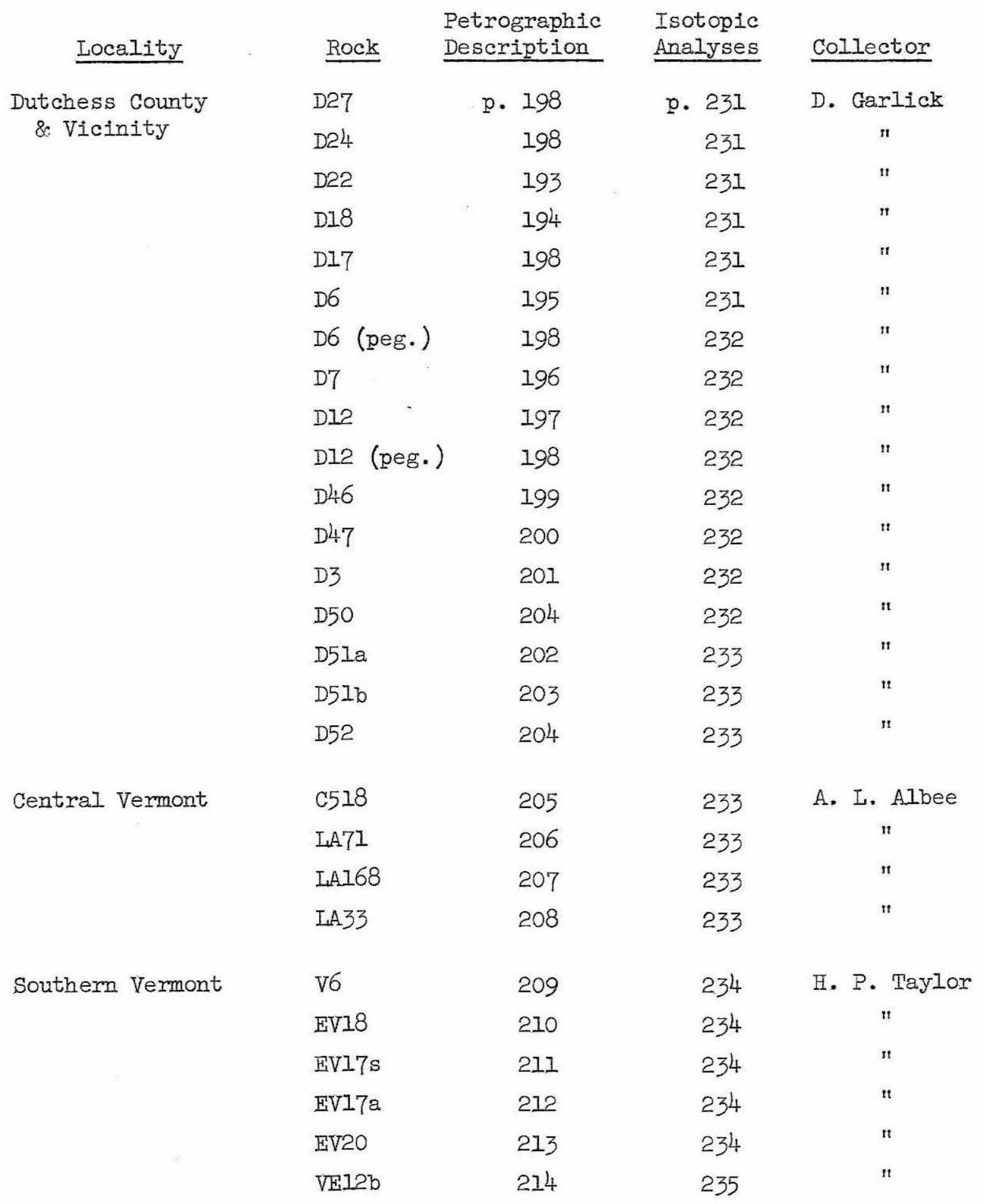


INDEX TO APPENDICES-Continued

\begin{tabular}{|c|c|c|c|c|}
\hline Locality & Rock & $\begin{array}{l}\text { Petrographic } \\
\text { Description }\end{array}$ & $\begin{array}{l}\text { Isotopic } \\
\text { Analyses }\end{array}$ & Collector \\
\hline \multirow[t]{14}{*}{ Southern Vermont } & P12a & p. 217 & p. 235 & J.L. Rosenfeld \\
\hline & RCC & 215 & 235 & $"$ \\
\hline & $\mathrm{RZ}$ & 217 & 235 & $"$ \\
\hline & F22b & 217 & 235 & $"$ \\
\hline & $\mathbf{S} 35 j$ & 216 & 235 & 11 \\
\hline & $\mathrm{GBF} 3$ & 219 & 236 & R. Naylor \\
\hline & GBFI & 219 & 236 & $"$ \\
\hline & $4167 \mathrm{~g}$ & 218 & 236 & $"$ \\
\hline & $4182 c$ & 219 & 236 & $"$ \\
\hline & 4042 & 219 & 236 & $n$ \\
\hline & $4186 c$ & 220 & 236 & $\pi$ \\
\hline & $4186 \mathrm{~g}$ & 221 & 236 & $"$ \\
\hline & CSG3 & 222 & 236 & $"$ \\
\hline & CSGI & 222 & 236 & $"$ \\
\hline \multirow{5}{*}{ Central Connecticut } & A66a & 223 & 236 & J.L. Rosenfeld \\
\hline & A $57 \mathrm{~d}$ & 224 & 237 & " \\
\hline & Al5h4 & 224 & 237 & $"$ \\
\hline & A56j & 224 & 237 & $n$ \\
\hline & $\mathrm{A} 64 \mathrm{~g}$ & 225 & 237 & $n$ \\
\hline \multirow[t]{5}{*}{ Northern Idaho } & AH2096 & 226 & 237 & A. Hietanen \\
\hline & 1319 & 227 & 237 & $"$ \\
\hline & 1321 & 227 & 238 & $"$ \\
\hline & $912 a$ & 227 & 238 & $n$ \\
\hline & $\mathrm{AH} 243$ & 228 & 238 & $"$ \\
\hline Ontario & SY22 & 229 & 238 & J. A. Grant \\
\hline \multirow[t]{2}{*}{ Butte, Montana } & QM & 230 & 238 & D. Garlick \\
\hline & 5536 & 230 & 238 & \\
\hline
\end{tabular}


- 192 -

APPENDIX 1

PETROGRAPHIC DESCRIPTIONS

(The Thompson Projections are Tentative) 
No. D22 Rock name: Garnet phyllite

Collected by: D. Garlick

Locality: Dutchess County, New York

Field relations: Iower garnet zone

Microscopic description:

$\begin{array}{clll}\% & \text { mineral } & \text { size }(\mathrm{mm}) & \text { shape } \\ 64 & \text { Muscovite } & 0.1 & \text { flakes } \\ 20 & \text { Quartz } & 0.1 & \text { equant } \\ 5 ? & \text { Plagioclase } & 0.1 & \text { equant } \\ 5 & \text { Garnet } & 1.0 & \text { euhedral } \\ 3 & \text { Chlorite } & 0.2 & \text { patches } \\ 2 & \text { Ilmenite } & 0.8 \times .1 & \text { plates } \\ 1 & \text { Tourmaline } & 0.1 & \text { euhedral } \\ 1 & \text { Graphite } & 0.3 & \text { dust } \\ 0.5 & \text { Biotite } & 0.3 & \text { flakes } \\ t r & \text { Magnetite } & & \text { subhedral }\end{array}$

\section{Comments:}

Ilmenite and muscovite are well-oriented.

Garnets are unaltered. Macroscopically, garnets are dark grey in color.

Chlorite is primary.

Ilmenite is slightly poikioblastic.

Chloritoid is reported in the vicinity by Barth (5).

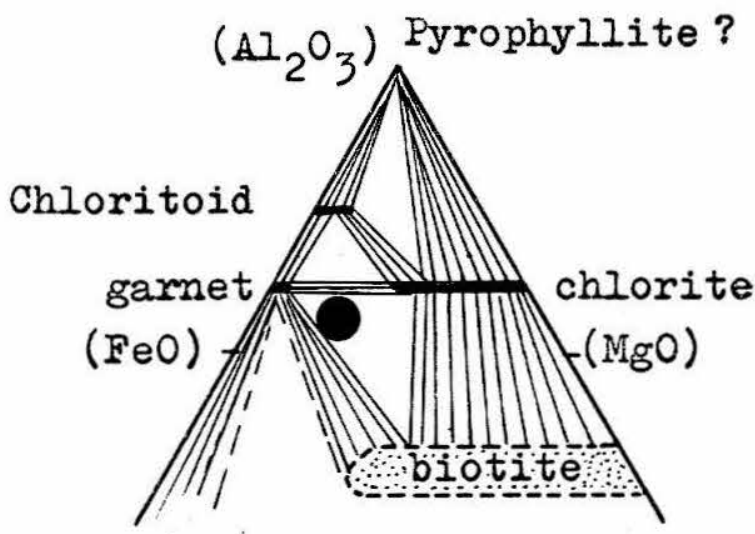


No. D18 Rock name: Garnet-staurolite schist

Collected by: D. Garlick

Iocality: Dutchess County, New York

Field relations: Staurolite-kyanite zone

Microscopic description:

\begin{tabular}{clcl}
$\%$ & mineral & size $(\mathrm{mm})$ & shape \\
\cline { 3 - 4 } 20 & Quartz & 0.3 & equant \\
20 & Muscovite & 0.5 & flakes \\
20 & Garnet & 2.0 & subhedral \\
17 & Biotite & 0.7 & books \\
15 & Staurolite & 2.0 & subhedral \\
$5 ?$ & Plagioclase & & \\
2 & Ilmenite & $0.3 \times 0.1$ & flakes \\
1 & Chlorite & 0.2 & flakes \\
tr & Tourmaline & 0.1 & euhedral
\end{tabular}

\section{Comments:}

Staurolite and garnet are poikioblastic. Chlorite occurs both as primary crystals and as selvages at garnet-staurolite contacts. Polysynthetic twinning is seen in plagioclase. Ilmenite is clean, coarse, and euhedral.

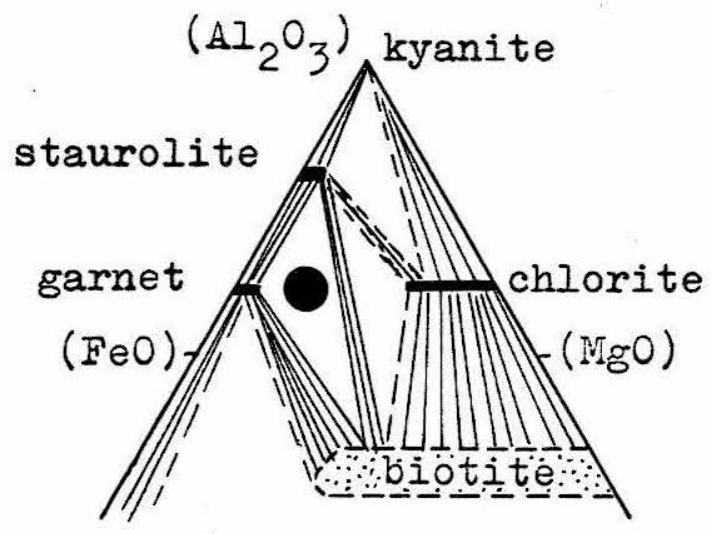


No. D6 Rock name: Mica schist

Collected by: D. Garlick

Locality: Dutchess County, New York

Field relations: Staurolite-sillimanite zone

Microscopic description:

\begin{tabular}{rlcl} 
\% & mineral & size $(\mathrm{mm})$ & shape \\
\cline { 3 - 4 } 25 & Quartz & 0.3 & equant \\
25 & Muscovite & 0.5 & flakes \\
13 & Plagioclase & 0.3 & equant \\
10 & Biotite & 0.5 & flakes \\
10 & Garnet & 1.0 & subhedral \\
10 & Staurolite & 2.0 & subhedral \\
5 & Sillimanite & & acicular masses \\
1 & Ilmenite & 0.2 & flakes \\
1 & Magnetite & 0.2 & anhedral \\
tr & Pyrite & 0.1 & subhedral \\
tr & Tourmaline & 0.5 & euhedral \\
tr & Sphene & &
\end{tabular}

Comments:

The schist is well-foliated. No chlorite was detected.

A few magnetite crystals contain cores of pyrite.

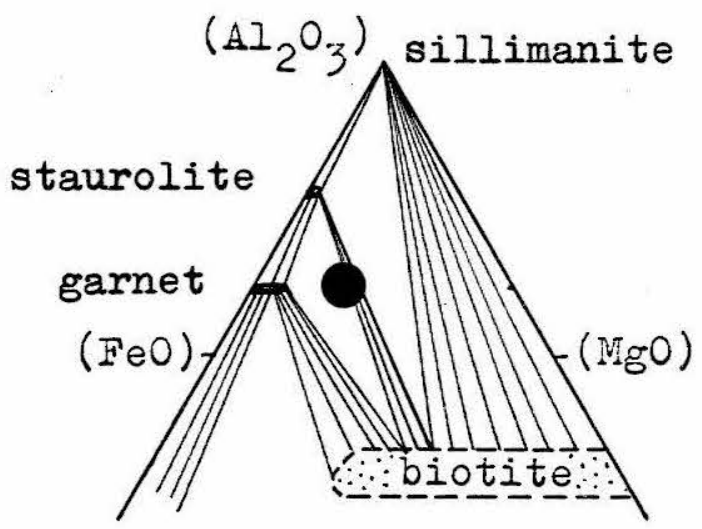


No. D7 Rock name: Plagioclase schist

Collected by: D. Garlick

Iocality: Dutchess County, New York

Field relations: Staurolite-sillimanite zone

Microscopic description:

$\begin{array}{rlll}\% & \text { mineral } & \text { size }(\mathrm{mm}) & \text { shape } \\ 40 & \text { Quartz } & 0.3 & \text { equant } \\ 40 & \text { Labradorite } & 0.5 & \text { equant } \\ 8 & \text { Garnet } & 1.0 & \text { anhedral } \\ 4 & \text { Muscovite } & 0.3 & \text { flakes } \\ 4 & \text { Biotite } & 0.3 & \text { flakes } \\ 2 & \text { Staurolite } & 0.3 & \text { anhedral } \\ 1 & \text { Magnetite } & 0.1 & \text { anhedral } \\ t r & \text { Apatite } & 0.1 & \text { subhedral } \\ t r & \text { Tourmaline } & 0.1 & \text { euhedral }\end{array}$

Comments:

Plagioclase shows albite and pericline twinning. Garnet is poikioblastic.

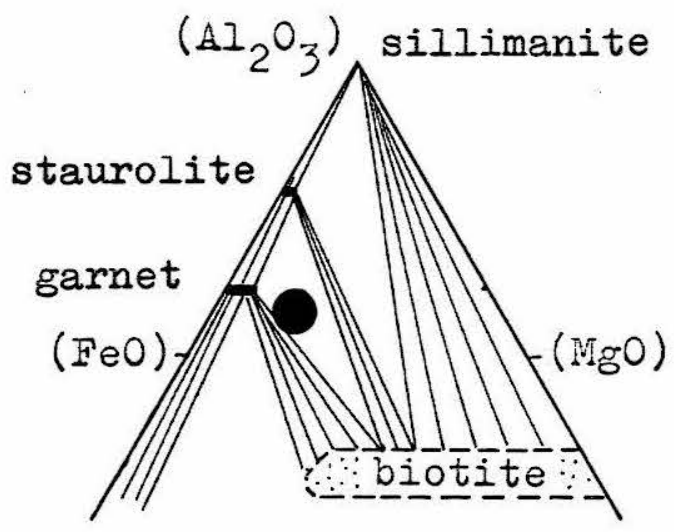


No. DI2 Rock name: Garnet schist

Collected by: D. Garlick

Iocality: Near Dutchess County, New York

Field relations: Sillimanite zone

Microssopic description:

\begin{tabular}{rlcl} 
\% & mineral & size $(\mathrm{mm})$ & shape \\
\cline { 3 - 4 } 40 & Quartz & 0.3 & equant \\
33 & Plagioclase & 0.8 & equant \\
10 & Garnet & 3.0 & subhedral \\
6 & Biotite & 0.6 & ragged \\
6 & Muscovite & 0.7 & ragged \\
3 & Sillimanite & 0.1 & acicular masses \\
2 & Magnetite & 0.1 & anhedral \\
$\operatorname{tr}$ & Chlorite & & \\
$\operatorname{tr}$ & Tourmaline & & euhedral
\end{tabular}

\section{Comments:}

Foliation in the schist is poorly developed. Plagioclase is usually polysynthetically twinned. Sillimanite is associated with mica. Traces of chlorite occur in some garnets, and is secondary. Magnetite is associated with traces of hematite and leucoxene.

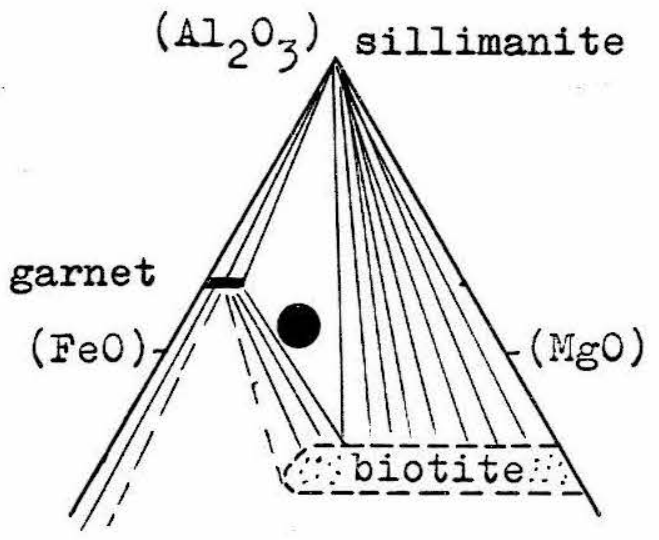


No. D27 Dutchess County. Muscovite zone. Grey slate cut by $5 \mathrm{~cm}$-wide quartz veins. Muscovite is the only recrystallized mineral.

No. D24 Dutchess County. Biotite zone. Fine-grained grey phyllite cut by $5 \mathrm{~cm}$-wide quartz veins. Both muscovite and biotite are recrystallized.

No. D17 Dutchess County. Staurolite-kyanite zone. Silicate segregation in marble, about $20 \mathrm{~cm}$ in diameter.

\begin{tabular}{|c|c|c|c|}
\hline$\%$ & Mineral & size (mm) & comments \\
\hline $\begin{array}{r}55 \\
20 \\
10 \\
10 \\
2 \\
1\end{array}$ & $\begin{array}{l}\text { Quartz } \\
\text { Calcite } \\
\text { Muscovite } \\
\text { Plagioclase } \\
\text { Biotite } \\
\text { Pyrite }\end{array}$ & $\begin{array}{l}1.0 \\
1.0 \\
0.5 \\
0.5 \\
0.5 \\
0.1\end{array}$ & $\begin{array}{l}\text { undulatory extinction } \\
\text { anhedral } \\
\text { flakes } \\
\text { poikioblastic } \\
\text { pale brown } \\
\text { anhedral }\end{array}$ \\
\hline
\end{tabular}

No. D6 (pegmatite) Dutchess County. Sillimanite zone. The pegmatite is conformable with the schists, and is about 0.3 meters wide.

\begin{tabular}{rlll}
$\%$ & Mineral & size $(\mathrm{mm})$ & \\
\hline 70 & Quartz & 1.0 & comments \\
25 & Oligoclase & 5.0 & saccharoidal \\
3 & Muscovite & 5.0 & subhedral \\
2 & Tourmaline & 1.0 & books \\
prismatic
\end{tabular}

No. D12 (pegmatite) Dutchess County. Sillimanite zone. The pegmatite is conformable with the schists, and is 0.7 meters wide. The mineralogy is similar to that of D6 (pegmatite). 
No. D46 Rock name: Amphibolite

Collected by: D. Garlick

Locality: Near Dutchess County, New York

Field relations: Sillimanite zone

Microscopic description:

$\begin{array}{rlcl}\% & \text { mineral } & \text { size }(\mathrm{mm}) & \text { shape } \\ 50 & \text { Andesine } & 0.7 & \text { equant } \\ 36 & \text { Hornblende } & 1.0 & \text { equant } \\ 7 & \text { Quartz } & 0.2 & \text { equant } \\ 5 & \text { Magnetite } & 0.3 & \text { irregular } \\ 1 & \text { Hematite } & 0.3 & \text { irregular }\end{array}$

Comments:

Foliation is poorly developed. Some compositional banding is seen at $30^{\circ}$ to foliation. Epidote is absent. The magnetite tends to be interstitial. 
No. D47 Rock name: Mica schist

Collected by: D. Garlick

Iocality: Near Dutchess County, New York

Field relations: Sillimanite zone

Microscopic description:

$\begin{array}{rlcl}\text { \% } & \text { mineral } & \text { size }(\mathrm{mm}) & \text { shape } \\ 35 & \text { Andesine } & 1.0 & \text { equant } \\ 30 & \text { Quartz } & 1.0 & \text { equant } \\ 22 & \text { Biotite } & 0.7 & \text { flakes } \\ 6 & \text { Garnet } & 1.5 & \text { subhedral } \\ 4 & \text { Muscovite } & 0.7 & \text { flakes } \\ 2 & \text { Sillimanite } & 0.1 & \text { acicular } \\ 1 & \text { Magnetite } & 0.1 & \text { subhedral } \\ t r & \text { Apatite } & 0.1 & \text { subhedral }\end{array}$

\section{Comments:}

The schist is well-foliated.

Plagioclase is polysynthetically twinned. Biotite tends to be interstitial.

Magnetite is commonly associated with biotite or garnet.

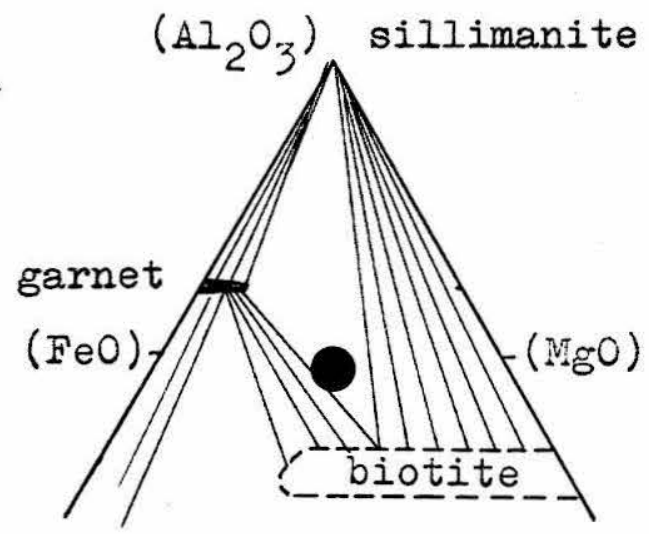


No. D3 Rock name: Gneiss

Collected by: D. Garlick

Iocality: Near Dutchess County, New York

Field relations: Sillimanite zone, Pre-cambrian gneiss

Microscopic description:

$\begin{array}{rlll}\text { \% } & \text { mineral } & \text { size }(\mathrm{mm}) & \text { shape } \\ 45 & \text { Microcline } & 1.0 & \text { irregular } \\ 32 & \text { Quartz } & 0.8 & \text { equant } \\ 10 & \text { Biotite } & 0.5 & \text { flakes } \\ 7 & \text { Muscovite } & 0.2 & \text { flakes } \\ 5 & \text { Oligoclase } & 0.3 & \text { equant } \\ 1 & \text { Zircon } & 0.3 & \text { euhedral } \\ t r & \text { Apatite } & 0.1 & \text { euhedral }\end{array}$

Comments:

Fo liation is fairly well-developed. Plagioclase crystals are commonly myrmekitic around edges.

Biotite is dark reddish-brown in color. 
No. D5la Rock name: Biotite schist

Collected by: D. Garlick.

Locality: Near Dutchess County, New York

Field relations: Interlaminated with pegmatitic granite, the contact of which is within 1 meter of the specimen.

Microscopic description:

\begin{tabular}{llll}
$\%$ & mineral & size $(\mathrm{mm})$ & shape \\
\cline { 3 - 4 } 40 & Quartz & 0.3 & equant \\
30 & Plagioclase & 0.3 & equant \\
29 & Biotite & 0.3 & flakes \\
1 & Muscovite & 0.1 & flakes \\
$\operatorname{tr}$ & Zircon & 0.05 & subhedral \\
tr & Apatite & 0.1 & subhedral
\end{tabular}

Comments:

Foliation is well-developed.

Plagioclase shows slight alteration along twin planes. Biotite is altered to chlorite adjacent to cracks in the rock. 
No. D5lb Rock name: Pegmatitic granite

Collected by: D. Garlick

Locality: Near Dutchess County, New York.

Field relations: Iit par lit intrusion into fine-grained biotite schist.

Microscopic description:

$\begin{array}{rlll}\% & \text { mineral } & \text { size }(\mathrm{mm}) & \text { shape } \\ 44 & \text { Microcline } & 0.1 \text { to } 5.0 & \text { equant } \\ 40 & \text { Quartz } & 2.0 & \text { equant } \\ 15 & \text { Tourmaline } & 1.0 & \text { fragments } \\ 1 & \text { Muscovite } & 0.2 & \text { flakes }\end{array}$

Comments:

Grain size is variable.

Tourmaline fragments represent slightly exploded crystals up to $5 \mathrm{~cm}$ in length. 
No. D50 Near Dutchess County. Sillimanite zone. Schist.

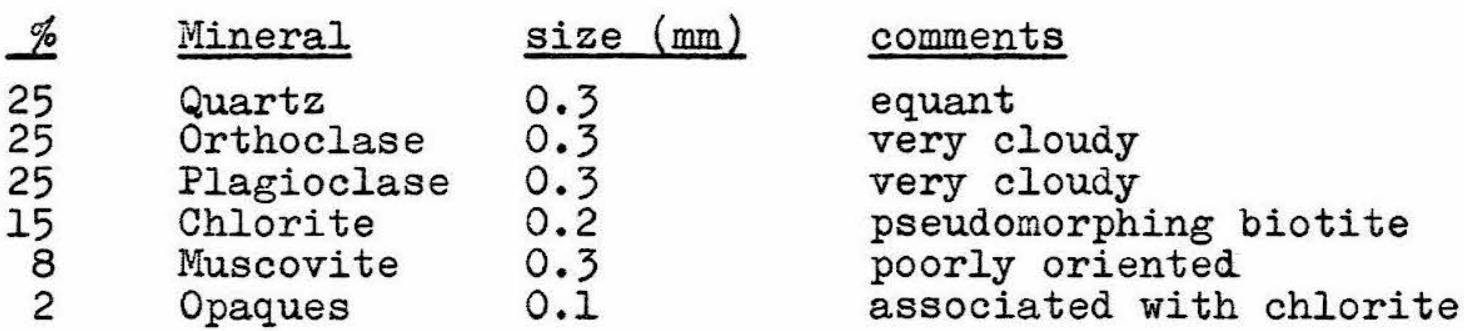

No. D52 Near Dutchess County. Sillimanite zone. Metadiorite.

\begin{tabular}{|c|c|c|c|}
\hline$\%$ & Mineral & size (mm) & comments \\
\hline 45 & Andesine & 1.0 & cloudy alteration \\
\hline 20 & Quartz & 0.7 & equant \\
\hline 20 & Biotite & 0.5 & fairly well-oriented \\
\hline 8 & Epidote & 0.2 & zoned, subhedral \\
\hline 6 & Hornblende & 0.3 & subhedral \\
\hline $\operatorname{tr}$ & Apatite & 0.1 & subhedral \\
\hline
\end{tabular}


No. C518 Rock name: Micaceous quartzitic schist

Collected by: A. I. Albee

Iocality: Central Vermont

Field relations: Biotite zone

Microscopic description:

$\begin{array}{rlll}\text { \% } & \text { mineral } & \text { size }(\mathrm{mm}) & \text { shape } \\ 30 & \text { Quartz } & 0.1 & \text { equant } \\ 27 & \text { Iluscovite } & 0.05 & \text { flakes } \\ 20 & \text { Plagioclase } & 0.1 & \text { equant } \\ 15 & \text { Biotite } & 0.1 & \text { subhedral } \\ 4 & \text { Chlorite } & 0.07 & \text { flakes } \\ 3 & \text { Ilmenite } & 0.05 & \text { flakes } \\ 1 & \text { Tourmaline } & 0.1 & \text { euhedral } \\ \operatorname{tr} & \text { Apatite } & 0.05 & \text { detrital } \\ \operatorname{tr} & \text { Zircon } & & \end{array}$

Comments:

The schist is poorly foliated.

The minerals appear to be completely recrystallized, with no sign of detrital cores. (Zircon is an exception.) Plagioclase is often twinned, and its refractive indices are less than those of quartz.

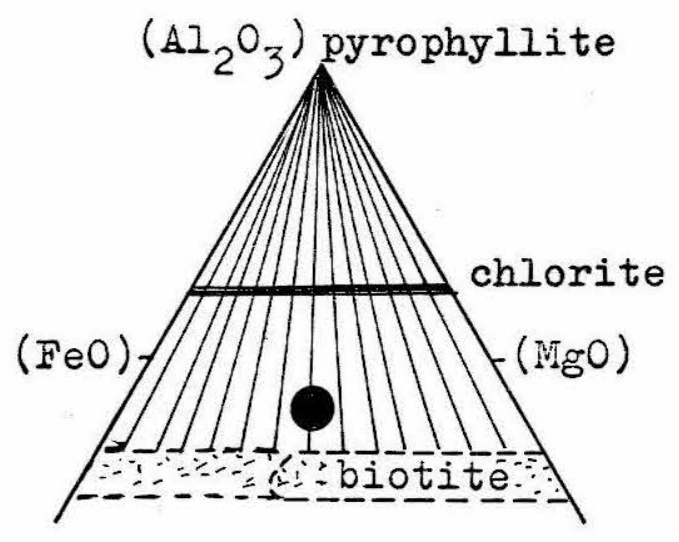


No. IA71 Rock name: Muscovite. schist

Collected by: A. I. Albee

Locality: Central Vermont

Field relations: Biotite zone, just west of garnet isograd and Precambrian rocks

Microscopic description:

$\%$ mineral

36 Quartz

30 Muscovite

10? Plagioclase

15 Chlorite

5 Biotite

2 Ilmenite

2 Calcite

tr Apatite size $(\mathrm{mm})$

0.1

0.1

0.1

0.1

0.4

0.1

0.2 shape

equant

flakes

equant

ragged

subhedral

flakes

interstitial

Comments:

The schist is well-foliated, but microfolded. Biotite is unoriented.

The largest metacrysts are biotite and calcite.

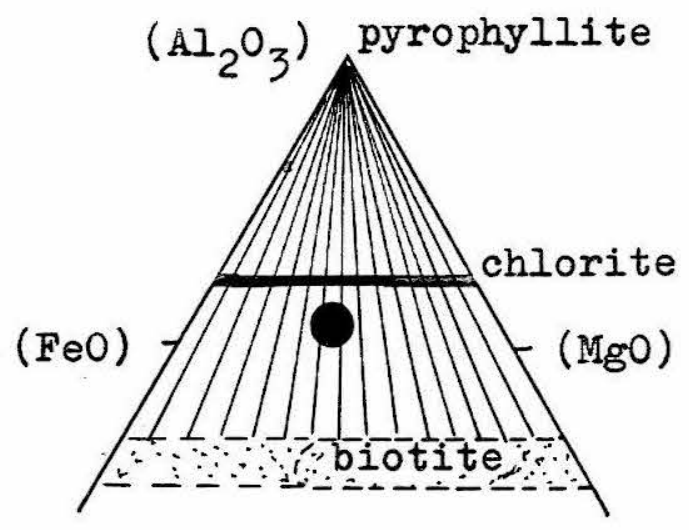


No. IAl68 Rock name: Albite-mica schist

Collected by: A. I. Albee

Locality: Mount Grant, central Vermont

Field relations: Chloritoid-kyanite zone

Microscopic description:

\begin{tabular}{llcl}
$\%$ & mineral & size $(\mathrm{mm})$ & shape \\
\cline { 3 - 4 } 40 & Quartz & 0.3 & irregular \\
20 & Albite & 1.5 & subhedral \\
20 & Muscovite & 0.3 & flakes \\
7 & Biotite & 1.0 & flakes \\
7 & Chlorite & 0.2 & interstitial \\
4 & Garnet & 0.8 & subhedral \\
2 & Ilmenite & 0.1 & plates
\end{tabular}

Comments:

The schist is well-foliated, with some microfolding.

The albite porphyroblasts show little twinning. Inclusions in the albite indicate that the crystals have been rotated. Quartz shows undulatory extinction under crossed polarizers. Quartz grain-boundaries are sutured.

Garnets are slightly altered to chiorite.

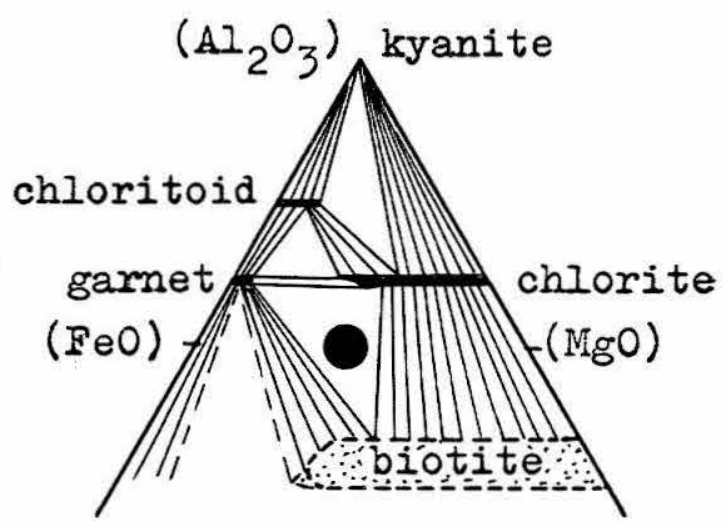


No. IA33 Rock name: Chlorite-chloritoid schist Collected by: A. I. Albee

Locality: Mt. Grant, central Vermont

Field relations: Chloritoid-kyanite zone

Microscopic description:

$\begin{array}{rlcl}\text { \% } & \text { mineral } & \text { size }(\mathrm{mm}) & \text { shape } \\ 40 & \text { Quartz } & 0.3 & \text { irregular } \\ 36 & \text { Muscovite } & 0.3 & \text { flakes } \\ 10 & \text { Chlorite } & 0.5 & \text { books } \\ 8 & \text { Chloritoid } & 0.3 & \text { subhedral } \\ 4 & \text { Garnet } & 2.0 & \text { irregular } \\ 2 & \text { Magnetite } & 0.5 & \text { irregular } \\ \text { tr } & \text { Tourmaline } & & \end{array}$

\section{Comments:}

Foliation is poorly developed, and microfolding is evident. Chloritoid is blue-pleochroic. Quartz grains show undulatory extinction under crossed polarizers. Quartz grain-boundaries are sutured. The chlorite appears to be primary. Garnet may be slightly chloritized.

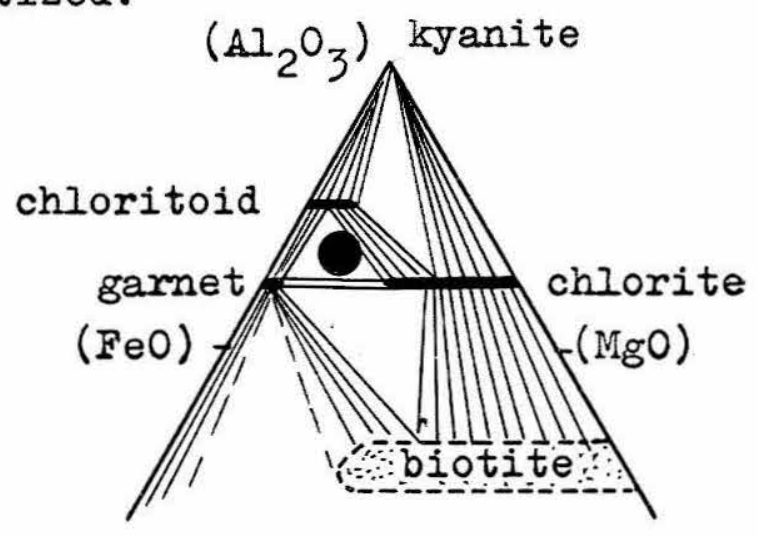


No. V6 Rock name: Muscovite schist

Collected by: H. P. Taylor

Iocality: Southern Vermont

Field relations: Biotite zone near garnet isograd.

Adjacent to eastern margin of Green Mountain basement rocks.

Microscopic description:

\begin{tabular}{llcl}
$\%$ & mineral & size $(\mathrm{mm})$ & shape \\
\cline { 3 - 3 } 60 & Quartz & 0.4 & equant \\
$14 ?$ & Plagioclase & 0.4 & equant \\
14 & Muscovite & 0.4 & flakes \\
5 & Biotite & 0.3 & flakes \\
2 & Zoisite & 0.1 & anhedral \\
1 & Chiorite & 0.2 & flakes \\
1 & Calcite & 0.2 & interstitial \\
1 & Pyrite & 0.4 & cubes \\
$t r$ & Tourmaline & 0.1 & subhedral
\end{tabular}

Comments:

The schist is well-foliated.

Twinning is seen in the oligoclase.

Occasional swarms of opaque material are seen.

The chlorite appears to be primary. 
No. EV18 Rock name: Chlorite-muscovite-plagioclase schist Collected by: H. P. Taylor

Iocality: Southern Vermont

Field relations: Garnet zone

Microscopic description:

\begin{tabular}{rlll}
\multicolumn{1}{c}{ mineral } & size $(\mathrm{mm})$ & shape \\
30 & Quartz & 0.4 & equant \\
30 & Oligoclase & 1.0 & anhedral \\
20 & Muscovite & 0.2 & flakes \\
10 & Chlorite & 0.4 & patches \\
3 & Magnetite & 0.7 & subhedral \\
2 & Garnet & 1.0 & remnants \\
2 & Biotite & 0.2 & flakes \\
2 & Hematite & 0.1 & plates \\
$t r$ & Calcite & 0.1 & interstitial
\end{tabular}

Comments:

The oligoclase is poikioblastic.

Muscovite is well-oriented, but unevenly distributed. Biotite is interleaved with chlorite.

Most of the chlorite is not associated with garnet or biotite.

Magnetite and hematite are not spatially associated. The hematite is well-oriented parallel to the foliation. 
No. EVI7s Rock name: Quartz-mica schist

Collected by: H. P. Taylor

Locality: Southern Vermont

Field relations: Garnet zone

Microscopic description:

$\begin{array}{clll}\% & \text { mineral } & \text { size }(\mathrm{mm}) & \text { shape } \\ 40 & \text { Quartz } & 0.3 & \text { equant } \\ 25 & \text { Muscovite } & 0.2 & \text { flakes } \\ 10 & \text { Biotite } & 0.3 & \text { flakes } \\ 10 & \text { Chlorite } & 0.5 & \text { flakes } \\ 7 ? & \text { Oligoclase } & 0.3 & \text { equant } \\ 5 & \text { Garnet } & 1.0 & \text { remnants } \\ 1 & \text { Magnetite } & 0.3 & \text { euhedral } \\ 1 & \text { Hematite } & 0.1 & \text { plates } \\ \text { tr } & \text { Epidote } & 0.1 & \text { subhedral } \\ \text { tr } & \text { Apatite } & 0.1 & \text { subhedral }\end{array}$

\section{Comments:}

The foliation is contorted on a microscopic scale. A part of the chlorite occurs as pseudomorphs after euhedral garnet. 
No. EVI7a Rock name: Amphibolite

Collected by: H. P. Taylor

Iocality: Southern Vermont

Field relations: Garnet zone

Microscopic description:

\begin{tabular}{rlll}
\multicolumn{1}{c}{ mineral } & size $(\mathrm{mm})$ & shape \\
40 & Andesine & 0.2 & equant \\
30 & Hornblende & 0.2 & euhedral \\
14 & Quartz & 0.2 & equant \\
8 & Chlorite & 0.1 & flakes \\
3 & Epidote & 0.1 & subhedral \\
$t r$ & Apatite & 0.1 & subhedral
\end{tabular}

\section{Comments:}

The hornblende is fairly well-oriented. Chlorite is randomly oriented. $10 \%$ of the plagioclase occurs as $2 \mathrm{~mm}$ crystals containing fine-grained epidote. 
No. EV20 Rock name: quartz-mica schist

Collected by: H.P.Taylor

Locality: southern Vermont

Field relations: garnet zone, near Athens dome.

Microscopic description:

\begin{tabular}{rlll}
\multicolumn{1}{c}{ mineral } & size $(\mathrm{mm})$ & shape \\
42 & muscovite & 0.5 & flakes \\
37 & quartz & 0.5 & equant \\
10 & biotite & 0.8 & flakes \\
8 & chlorite & 1.0 & books \\
2 & garnet & 0.5 & irregular \\
1 & ilmenite & 0.2 & plates \\
$\operatorname{Tr}$. & magnetite & &
\end{tabular}

Comments:

Muscovite and ilmenite are well-oriented, biotite is less well-oriented.

Although a minor portion of the chlorite may be primary, the bulk is secondary, replacing garnet.

Garnet metacrysts were originally about $4 \mathrm{~mm}$ in diameter. 
No. VEl2b Rock name: Staurolite schist

Collected by: H. P. Taylor

Iocality: Chester Dome, southern Vermont

Field relations: Staurolite-kyanite zone

Field name: Gassetts schist, Cavendish formation

Microscopic description:

$\begin{array}{rlcl}\% & \text { mineral } & \text { size }(\mathrm{mm}) & \text { shape } \\ 33 & \text { Quartz } & 2.0 & \text { inequigranular } \\ 30 & \text { Muscovite } & 1.0 & \text { flakes } \\ 17 & \text { Staurolite } & 2.0 & \text { euhedral } \\ 10 & \text { Garnet } & 2.0 & \text { subhedral } \\ 5 & \text { Biotite } & 0.5 & \text { flakes } \\ 2 & \text { Chlorite } & 0.5 & \text { subhedral } \\ 2 & \text { Apatite } & 0.3 & \text { anhedral } \\ 1 & \text { Magnetite } & 0.1 \times 0.3 & \text { subhedral }\end{array}$

Comments:

Foliation is fairly well-developed.

Biotite is often concentrated around garnet.

Chlorite is sometimes interlaminated with biotite, and may be of secondary origin.

Rock contains paragonite.

Magnetite is associated with small quantities of hematite. Some garnets are rimmed by Chlorite which is presumably of secondary origin.

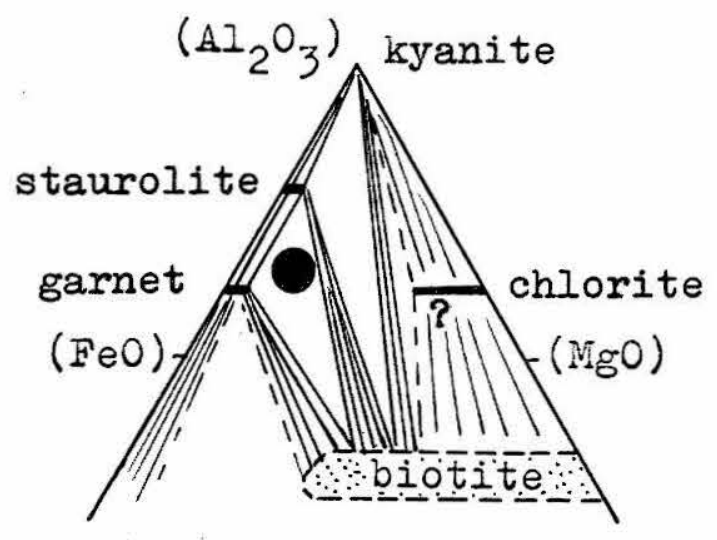


No. RCC Rock name: Amphibolite

Collected by: J. I. Rosenfeld

Iocality: Southern Vermont

Field relations: Staurolite-kyanite zone

Microscopic description:

$\begin{array}{rlll}\% & \text { mineral } & \text { size }(\mathrm{mm}) & \text { shape } \\ 70 & \text { Hornblende } & 0.3 & \text { prismatic } \\ 8 & \text { Oligoclase } & 0.2 & \text { equant } \\ 7 & \text { Quartz } & 0.2 & \text { equant } \\ 4 & \text { Epidote } & 0.1 & \text { anhedral } \\ 4 & \text { Calcite } & 0.3 & \text { irregular } \\ 3 & \text { Chlorite } & 0.2 & \text { flakes } \\ 2 & \text { Magnetite } & 0.1 & \text { subhedral } \\ 1 & \text { Biotite } & 0.1 & \text { flakes }\end{array}$

Comments:

The amphibolite is well-laminated. The chlorite is not well-oriented.

A part of the chlorite is fine-grained, associated with calcite, and possibly of secondary origin.

The plagioclase is rarely twinned. 
No. S35j Rock name: Garnet-mica schist

Collected by: J. I. Rosenfeld

Iocality: Southern Vermont

Field relations: Staurolite-kyanite zone

Microscopic description:

\begin{tabular}{rlll}
\multicolumn{1}{c}{ \% } & mineral & size $(\mathrm{mm})$ & shape \\
40 & Quartz & 0.5 & equant \\
30 & Muscovite & 0.3 & flakes \\
17 & Garnet & 7.0 & subhedral \\
4 & Staurolite & 1.0 & euhedral \\
3 & Biotite & 0.2 & flakes \\
3 & Chlorite & 0.2 & flakes \\
1 & Opaques & 0.1 & elongate \\
tr & Apatite & 0.1 & subhedral
\end{tabular}

\section{Comments:}

The schist is well-foliated.

Chlorite appears to be primary. Garnet is not chloritized.

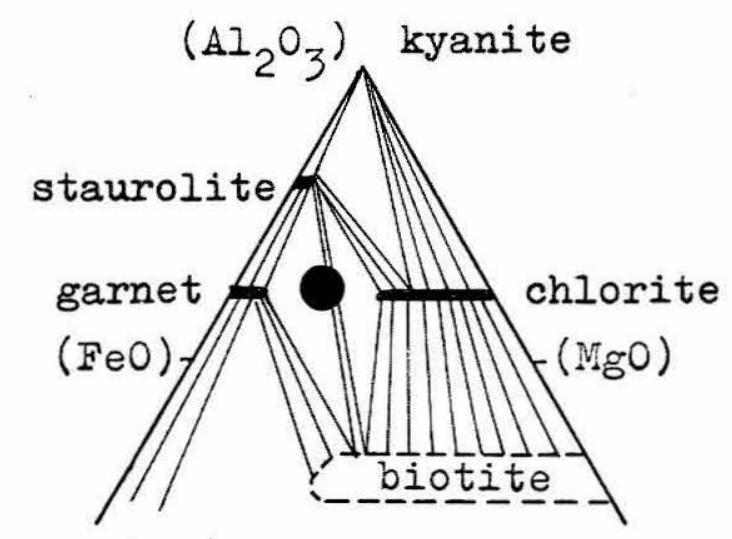




\section{No. P12a Southern Vermont. Garnet zone.}

Garnet porphyroblast ( $5 \mathrm{~cm}$ in diameter) with spirally arranged inclusions of quartz $(0.5 \mathrm{~mm})$, minor calcite, and opaques.

No. RZ Southern Vermont. Staurolite-kyanite zone. Garnet-mica schist.

$\begin{aligned} \frac{\%}{35} & \text { Mineral } & \text { size }(\mathrm{mm}) & \text { comments } \\ 33 & \text { Quartz } & 0.3 & \text { equant } \\ 25 & \text { Garnetite } & 0.2 & \text { well-oriented } \\ 5 & \text { Chlorite } & 0.0 & \text { euhedral } \\ 1 & \text { Opaques } & 0.1 & \text { poorly oriented }\end{aligned}$

A part of the chlorite is pseudomorphing garnet.

No. F22b Southern Vermont. Staurolite-kyanite zone. Garnet schist

\begin{tabular}{|c|c|c|c|}
\hline$\%$ & Mineral & size $(\mathrm{mm})$ & comments \\
\hline 30 & Garnet & 5.0 & euhedral, rolled \\
\hline 15 & Quartz & 0.5 & equant \\
\hline 15 & Muscovite & 0.3 & contorted foliation \\
\hline 10 & Oligoclase & 0.8 & albite twinning \\
\hline 7 & Staurolite & 0.8 & subhedral \\
\hline 7 & Kyanite & 1.0 & euhedral \\
\hline 7 & Biotite & 0.3 & associated with chlorite \\
\hline 7 & Chlorite & 0.3 & primary \\
\hline$i$ & Opaques & 0.1 & irregular \\
\hline $\operatorname{tr}$ & Rutile & 0.1 & irregular \\
\hline $\operatorname{tr}$ & Tourmaline & 0.1 & subhedral \\
\hline
\end{tabular}


No. $4167 \mathrm{~g}$ Rock name: Feldspathic gneiss

Collected by: R. Naylor

Iocality: Southern Vermont, Green Mountains.

Field relations: Pre-cambrian gneiss remetamorphosed to garnet grade.

Microscopic description:

$\begin{array}{cll}\% & \text { mineral } \\ 50 & & \text { Oligoclase } \\ 25 & & \text { Quartz } \\ 8 & & \text { Biotite } \\ 5 & & \text { Epidote } \\ 3 & & \text { Garnet } \\ 3 & \text { Chlorite } \\ 3 & \text { Magnetite } \\ 2 & \text { Muscovite } \\ 1 & \text { Tourmaline } \\ 1 & \text { Apatite }\end{array}$

$\begin{aligned} & \text { size (mm) } \\ & 1.0 \\ & 0.7 \\ & 0.3 \\ &<0.1 \\ & 0.2 \\ & 0.2 \\ & 0.5 \\ &<0.1 \\ & 2.0 \\ & 0.2\end{aligned}$

shape equant irregular flakes subhedral euhedral flakes euhedral flakes subhedral subhedral

Comments:

Foliation is poorly developed.

Plagioclase is partly replaced by epidote. Polysynthetic twinning is absent in most of the plagioclase crystals. 
No. GBFI Southern Vermont. Pre-cambrian. Quartz-muscovite-feldspar pegmatite. Shows evidence of shearing.

No. GBF3 Southern Vermont. Pre-cambrian. Clean quartzite containing less than $1 \%$ magnetite. Grain size: quartz $-0.5 \mathrm{~mm}$ magnetite $-0.1 \mathrm{~mm}$.

No. 4182c Southern Vermont. Staurolite-kyanite zone. Mica schist (Cavendish formation).

\begin{tabular}{|c|c|c|c|}
\hline$\%$ & Mineral & size $(\mathrm{mm})$ & comments \\
\hline $\begin{array}{l}35 \\
25\end{array}$ & $\begin{array}{l}\text { Quartz } \\
\text { Oligoclase }\end{array}$ & $\begin{array}{l}0.3 \\
0.6\end{array}$ & $\begin{array}{l}\text { equant } \\
\text { twinning uncommon }\end{array}$ \\
\hline 20 & Muscovite & 0.2 & well-oriented \\
\hline 18 & Biotite & 0.2 & well-oriented \\
\hline 1 & Sphene & $<0.1$ & anhedral \\
\hline $\operatorname{tr}$ & Apatite & $<0.1$ & subhedral \\
\hline tr & Opaques & $<0.1$ & irregular \\
\hline $\operatorname{tr}$ & Hematite & $<07$ & irregular \\
\hline
\end{tabular}

No. 4042 Southern Vermont. Staurolite-kyanite zone. Garnet-staurolite schist (Cavendish formation).

\begin{aligned}$\% &$ Mineral & size $(\mathrm{mm}) &$ comments \\ \hline 30 & Quartz & 0.5 & equant \\ 20 & Muscovite & 0.5 & well-oriented \\ 20 & Garnet & 12.0 & euhedral \\ 20 & Staurolite & 6.0 & euhedral \\ 4 & Opaques & 0.1 & elongate \& oriented \\ 3 & Chlorite & 0.2 & flakes \\ 1 & Biotite & 0.2 & flakes \\ $\operatorname{tr} &$ Apatite & 0.3 & subhedral \end{aligned}

A part of the chlorite is secondary, replacing garnet. 
No. $4186 \mathrm{c}$ Rock name: Schist renolith

Collected by: R. Naylor

Iocality: Chester Dome, southern Vermont

Field relations: Xenolith in trondjemite

Microscopic description:

\begin{aligned}$\% &$ mineral & size $(\mathrm{mm}) &$ shape \\ \cline { 3 - 4 } 60 & Muscovite & 1.0 & flakes \\ 15 & Biotite & 1.0 & flakes \\ 15 & Quartz & 0.4 & interstitial \\ 5 & Garnet & 1.0 & irregular remnants \\ 3 & Chlorite & 0.4 & flakes \\ 1 & Tourmaline & 0.5 & euhedral \\ 1 & Ilmenite & 0.1 & equant \end{aligned}

\section{Comments:}

Muscovite is well-oriented.

Biotite is foliated around garnets.

Chlorite, muscovite, and biotite occur between garnet remnants.

One unbroken tourmaline crystal, $3 \mathrm{~mm}$ long, was found in the thin-section.

No feldspar was found.

Quartz shows undulatory extinction under crossed polarizers. 
No. $4186 \mathrm{~g}$ Rock name: Trondjemite

Collected by: R. Naylor

Locality: Chester Dome, Vermont

Field relations: Small stock intruding Reading gneiss.

Microscopic description:

\begin{aligned}$\% &$ mineral & size $(\mathrm{mm}) &$ shape \\ \cline { 3 - 4 } & Oligoclase & 2.0 & equant \\ 11 & Quartz & 1.0 & equant \\ 3 & Microcline & 1.0 & equant \\ 2 & Muscovite & 0.5 & flakes \\ 1 & Biotite & 0.3 & flakes \\ tr & Zoisite & & \end{aligned}

\section{Comments:}

The plagioclase is noticeably zoned, polysynthetically twinned, occasionally myrmekitic, and usually slightly altered. 
No. CSGI Southern Vermont. Staurolite-kyanite zone. Reading gneiss (Chester dome).

\begin{tabular}{|c|c|c|c|}
\hline$\%$ & Mineral & size (mm) & comments \\
\hline & Oligoclase & 0.4 & seldom twinned \\
\hline 35 & Quartz & 0.4 & equant \\
\hline 4 & Biotite & 0.3 & well-oriented \\
\hline 4 & Epidote & 0.1 & subhedral \\
\hline 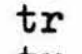 & Pyrite & 0.1 & anhedral \\
\hline $\operatorname{tr}$ & Apatite & 0.1 & subhedral \\
\hline tr & Chlorite & 0.1 & secondary \\
\hline
\end{tabular}

No. CSG3 Granitic dyke intruding Reading gneiss. 
No. A66a Rock name: Clough quartzite

Collected by: J. I. Rosenfeld

Iocality: Central Connecticut

Field relations: Staurolite-kyanite zone

Microscopic description:

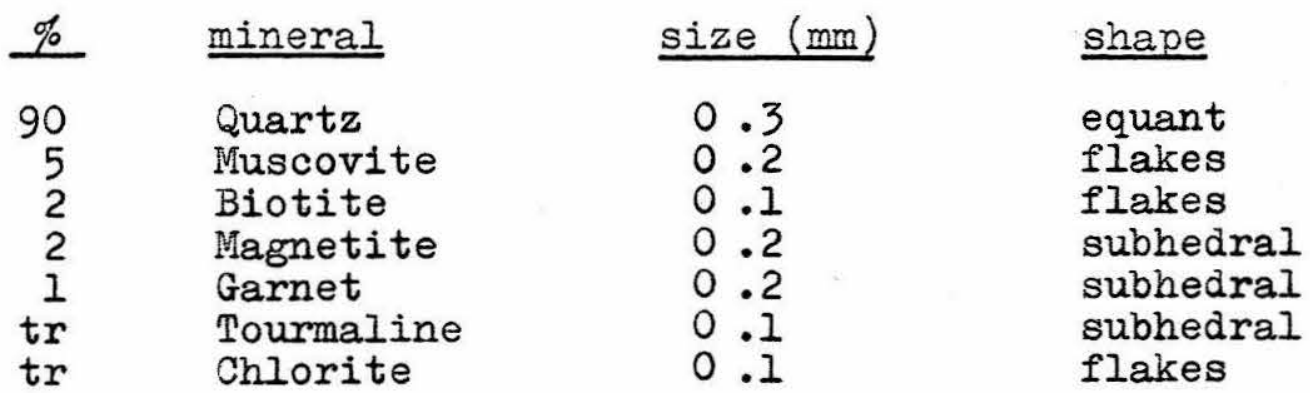

\section{Comments:}

Muscovite is well-oriented. Magnetite is clean.

Chlorite appears to be primary. 
No. A57d Central Connecticut. Staurolite-kyanite zone. Clough Quartzite.

$\begin{array}{rll}\frac{\%}{90} & \text { Mineral } & \text { size }(\mathrm{mm}) \\ 4 & \text { Quartz } & 1.0 \\ 2 & \text { Muscovite } & 0.5 \\ 1 & \text { Giotite } & 0.5 \\ \text { tr } & \text { Chlorite } & 0.5 \\ \text { tr } & \text { Ilmenite } & 0.2 \\ & & 0.1\end{array}$

comments

variable grain-size

well-oriented

poikioblastic

well-oriented

replacing garnet

anhedral

No. Al5h4 Central Connecticut. Staurolite-sillimanite. Amphibolite.

$\begin{array}{rlll}\% & \text { Mineral } & \frac{\text { size }(\mathrm{mm})}{\text { comments }} \\ 85 & \text { Hornblende } & 1.0 \times 0.5 & \text { prismatic } \\ 5 & \text { Plagioclase } & 0.8 & \text { albite twinning } \\ 5 & \text { Biotite } & 0.5 & \text { interstitial } \\ 4 & \text { Quartz } & 0.5 & \text { equant } \\ \text { tr } & \text { Opaques } & 0.3 & \text { interstitial }\end{array}$

No. A56j Central Connecticut. Staurolite-sillimanite. Garnet schist.

$\begin{array}{rlll}\text { \% } & \text { Mineral } & \text { size (mm) } & \text { comments } \\ 45 & \text { Quartz } & 1.0 & \text { equant } \\ 20 & \text { Garnet } & 3.0 & \text { poikioblastic } \\ 20 & \text { Biotite } & 0.8 & \text { fairly well-oriented } \\ 10 & \text { Oligoclase } & 0.8 & \text { albite twinning } \\ 3 & \text { Staurolite } & 0.5 & \text { anhedral } \\ 1 & \text { Sillimanite } & 0.05 & \text { fibrous, with biotite } \\ \text { tr } & \text { Chlorite } & 0.3 & \text { replacing garnet }\end{array}$


No. A64g Rock name: Sillimanite gneiss

Collected by: J. I. Rosenfeld

Locality: Southern Connecticut

Field relations: Orthoclase-sillimanite zone

Microscopic description:

$\begin{array}{rlcl}\% & \text { mineral } & \text { size }(\mathrm{mm}) & \text { shape } \\ 40 & \text { Quartz } & 1.0 & \text { equant } \\ 20 & \text { Andesine } & 1.0 & \text { equant } \\ 15 & \text { Garnet } & 2.0 & \text { anhedral } \\ 15 & \text { Biotite } & 0.8 & \text { irregular } \\ 8 & \text { Sillimanite } & 0.1 & \text { thick acicular } \\ 1 & \text { Ilmenite } & 0.2 & \text { irregular } \\ 1 ? & \text { Orthoclase } & & \end{array}$

Comments:

Sillimanite well-oriented. Biotite is poorly oriented. Muscovite is absent.

Plagioclase is fairly well-twinned, and in some cases contains vermicular quartz. Traces of alteration-minerals along cracks.

Ilmenite occurs as irregular grains commonfy associated with sillimanite. Traces of leucoxene are present.

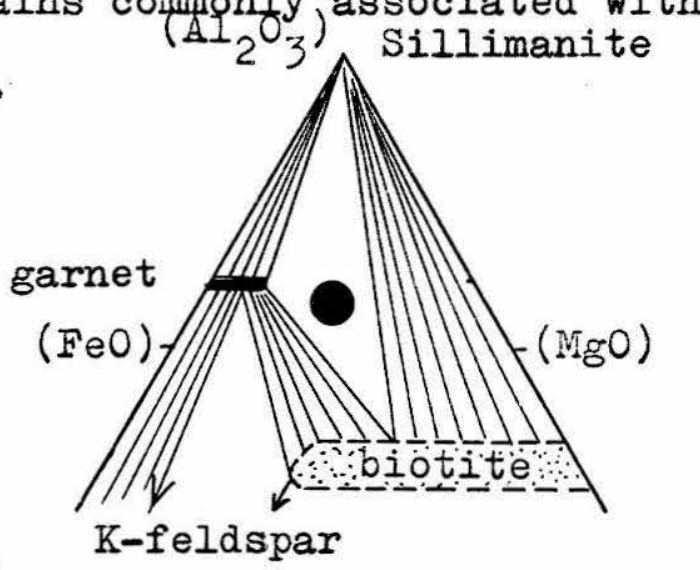


No. AH2096 Rock name: Staurolite schist

Collected by: A. Hietanen

Iocality: Shoshone County, northern Idaho

Field relations: Staurolite-kyanite zone

Microscopic description:

$\begin{array}{clcl}\% & \text { mineral } & \text { size }(\mathrm{mm}) & \text { shape } \\ 61 & \text { Quartz } & 0.2 & \text { equant } \\ 10 & \text { Biotite } & 0.2 & \text { flakes } \\ 10 & \text { Staurolite } & 8.0 & \text { poikioblastic } \\ 6 & \text { Muscovite } & 0.1 & \text { flakes } \\ 5 & \text { Garnet } & 1.0 & \text { irregular } \\ 5 ? & \text { Plagioclase } & & \\ 2 & \text { Chlorite } & 1.0 & \text { subhedral } \\ 1 & \text { Ilmenite } & 0.1 & \text { flakes }\end{array}$

Comments:

Micas are well-foliated.

Compositional banding is seen at an angle to the foliation. Staurolite metacrysts contain $50 \%$ quartz.

Chlorite crystals are not oriented parallel to the foliation. Ilmenite flakes are clean.

A mineral similar in appearance to leucoxene occurs, but it is not associated with ilmenite.

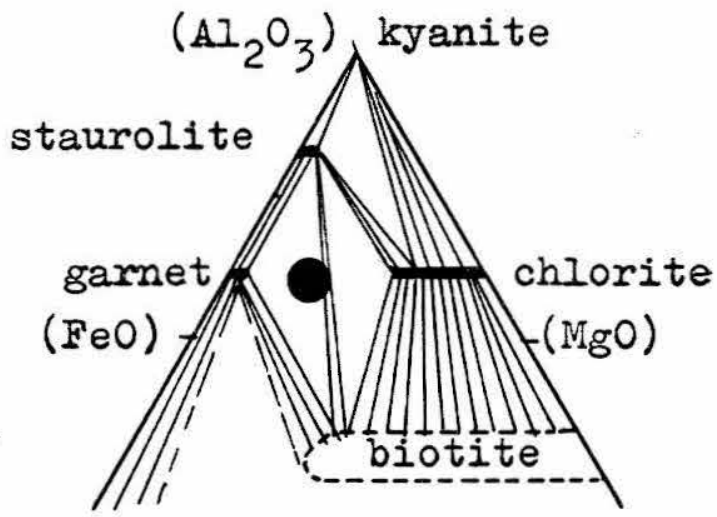


No. 1319 Northern Idaho. Zone containing kyanite, sillimanite \& andalusite.

Inclusion of schist in anorthosite which may be of metasomatic origin.

$\begin{array}{llll}\frac{\text { Mineral }}{25} & \text { Mize }(\mathrm{mm}) & & \text { comments } \\ 25 & \text { Quartz } & 1.0 & \text { sutured grain boundaries } \\ 20 & \text { Oligoclase } & 2.0 & \text { untwinned } \\ 20 & \text { Chlorite } & 1.0 & \text { fairly well-oriented } \\ 10 & \text { Kyanite } & 8.0 & \text { abundant inclusions }\end{array}$

The garnet is not appreciably chloritized.

No. 1321 Northern Idaho. Zone containing kyanite, sillimanite \& andalusite.

Garnet amphibolite.

\begin{tabular}{rlll}
$\%$ & Mineral & size $(\mathrm{mm})$ & comments \\
\cline { 2 - 3 } 40 & Hormblende & 1.0 & fairly well-oriented \\
35 & Andesine & 1.0 & twinning uncommon \\
15 & Quartz & 0.8 & equant \\
5 & Garnet & 2.0 & poikioblastic \\
3 & Opaques & 0.2 & irregular
\end{tabular}

No. 912a Northern Idaho. Zone containing kyanite, sillimanite \& andalusite.

Plagioclase-mica schist.

\begin{tabular}{|c|c|c|c|}
\hline$\%$ & Mineral & size $(\mathrm{mm})$ & comments \\
\hline $\begin{array}{r}30 \\
30 \\
15 \\
10 \\
6 \\
5\end{array}$ & $\begin{array}{l}\text { Oligoclase } \\
\text { Muscovite } \\
\text { Quartz } \\
\text { Biotite } \\
\text { Tourmaline } \\
\text { Kyanite } \\
\text { Sillimanite }\end{array}$ & $\begin{array}{l}1.5 \\
0.8 \\
0.6 \\
0.8 \\
0.6 \\
2.0 \\
0.1\end{array}$ & $\begin{array}{l}\text { albite twinning } \\
\text { poorly oriented } \\
\text { irregular } \\
\text { pale green, Mg-rich } \\
\text { pale blue } \\
\text { partially replaced by } \\
\text { acicular sillimanite }\end{array}$ \\
\hline
\end{tabular}


No. AH243 Rock name: Sillimanite gneiss

Collected by: A. Hietanen

Iocality: Clearwater County, northern Idaho

Field relations: Sillimanite zone, $6 \mathrm{~km}$ northwest of the Boulder Batholith.

Microscopic description:

\begin{tabular}{rlcl}
$\%$ & mineral & size (mm) & shape \\
\cline { 3 - 4 } 62 & Quartz & 1.0 & equant \\
15 & Biotite & 0.7 & subhedral \\
10 & Muscovite & 1.0 & irregular \\
5 & Sillimanite & & acicular \\
4 & Garnet & 3.0 & anhedral \\
3 & Chlorite & 1.0 & masses \\
1 & Ilmenite & $0.1 \times 0.5$ & irregular \\
& Plagioclase? & &
\end{tabular}

\section{Comments:}

Biotite and sillimanite are well-oriented.

Muscovite cleavage generally occurs at an angle of $50^{\circ}$ to the foliation.

Muscovite is poikioblastic.

Yellowish chlorite is secondary; it is found replacing biotite.

Chlorite masses contain opaque particles $0.1 \mathrm{~mm}$ long.

Garnet is devoid of chloritization. Irregular crystals of ilmenite are fairly clean, but a trace of leucoxene does occur.

Very fine sillimanite occurs around the edges of some biotite crystals.

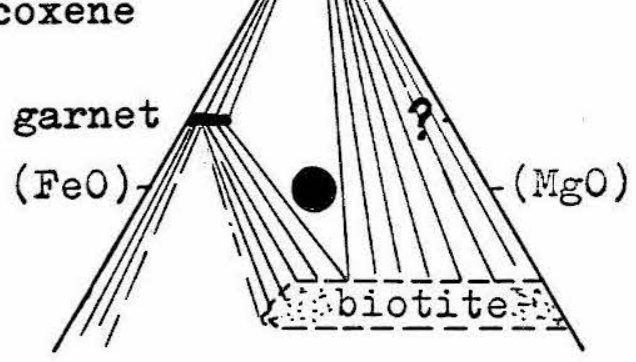


No. SY22 Rock name: Kyanite gneiss.

Collected by: J. Grant.

Iocality: Northern Kyanite Hines, Dryden Township, Ontario.

Field relations: Pre-cambrian Killarnean System. Sillimanite occurs in adjacent shear zones.

Microscopic description:

$\begin{array}{llll}\% & \text { mineral } & \text { size }(\mathrm{mm}) & \text { shape } \\ 35 & \text { Oligoclase } & 2.0 & \text { equant } \\ 15 & \text { Quartz } & 0.8 & \text { irregular } \\ 15 & \text { Kyanite } & 1.5 & \text { anhedral } \\ 15 & \text { Garnet } & 5.0 & \text { anhedral } \\ 15 & \text { Biotite } & 0.8 & \text { subhedral } \\ 1 & \text { Pyrite } & 0.2 & \text { anhedral }\end{array}$

\section{Comments:}

Plagioclase exhibits albite twinning. Biotite is reddish brown in color. foliation is poorly developed.

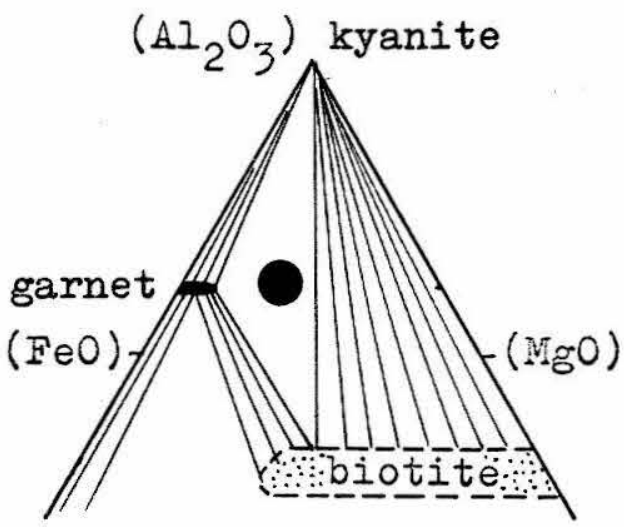




\begin{tabular}{clll} 
No. QM & \multicolumn{2}{c}{$\begin{array}{c}\text { Butte, Montana. } \\
\text { Quartz monzonite. }\end{array}$} & Plutonic igneous rock. \\
$\frac{\text { Mineral }}{40}$ & $\frac{\text { size (mm) }}{\text { Andesine }}$ & 2.0 & comments \\
20 & Quartz & 1.0 & subhedral, often zoned \\
25 & Microcline & 2.0 & interstitial \\
8 & Hornblende & 1.0 & subroperthitic, untwinned \\
5 & Biotite & 1.0 & dark brown \\
1 & Magnetite & 0.2 & anhedral \\
$\frac{1}{2}$ & Chlorite & 0.2 & replacing biotite \\
tr & Apatite & 0.1 & subhedral
\end{tabular}

The hornblende, biotite, and magnetite are spatially associated. The feldspars are unaltered.

No. 5536 Butte, Montana. Hydrothermal alteration. Altered quartz monzonite from sericitic zone, sampled within a few centimeters of a hydrothermal quartz-rhodochrosite vein in the Bmma Mine.

Original minerals

Andesine

Quartz

Microcline

Hornblende

Biotite
Present pseudomorphs

very fine-grained aggregate of muscovite and minor quartz quartz (apparently unaltered) microcline (apparently unaltered) aggregate of carbonate, muscovite and pyrite aggregate of muscovite, carbonate and pyrite

Anhedral magnetite is replaced by subhedral pyrite. 
APPENDIX 2

ANALYTICAL RESUITS

\begin{tabular}{|c|c|c|c|c|c|}
\hline No. & Rock & Mineral & $\begin{array}{c}0^{18} / 0^{16} \\
(\text { permil })\end{array}$ & $\begin{array}{c}\text { Average } \\
\text { Deviation }\end{array}$ & $\begin{array}{l}\text { No. of } \\
\text { Runs }\end{array}$ \\
\hline \multirow[t]{2}{*}{ D27 } & slate & wh. rock & 15.4 & - & 1 \\
\hline & & quartz vein & $17 \cdot 7$ & - & 1 \\
\hline \multirow[t]{2}{*}{$D 24$} & slate & wh. rock & 14.2 & - & 1 \\
\hline & & quartz vein & 18.9 & - & 1 \\
\hline \multirow[t]{5}{*}{ D22 } & schist & quartz & 16.7 & 0.2 & 2 \\
\hline & & muscovite & 13.3 & 0.2 & 2 \\
\hline & & garmet & 11.7 & 0.3 & 2 \\
\hline & & biotite & 10.5 & - & 1 \\
\hline & & ilmenite & 6.2 & 0.1 & 2 \\
\hline \multirow[t]{6}{*}{$\mathrm{D} 18$} & schist & quartz & $15 \cdot 7$ & 0.2 & 3 \\
\hline & & muscovite & 12.5 & 0.2 & 2 \\
\hline & & garnet & 10.9 & - & 1 \\
\hline & & biotite & 10.2 & 0.1 & 2 \\
\hline & & ilmenite & 5.7 & 0.3 & 2 \\
\hline & & quartz vein & 15.1 & - & 1 \\
\hline \multirow[t]{3}{*}{ D17 } & marble & quartz & 22.3 & 0.2 & 3 \\
\hline & & calcite* & $20 \cdot 3$ & - & 1 \\
\hline & & muscovite & 19.7 & 0.1 & 2 \\
\hline \multirow[t]{6}{*}{ D6 } & schist & quartz & 15.4 & 0.1 & 2 \\
\hline & & muscovite & 12.9 & 0.2 & 2 \\
\hline & & garnet & 10.7 & 0.1 & 2 \\
\hline & & biotite & 10.4 & 0.1 & 2 \\
\hline & & ilmenite & 6.7 & 0.1 & 2 \\
\hline & & magnetite & 6.0 & 0.1 & 2 \\
\hline
\end{tabular}

*The $\delta \mathrm{C}^{13}$ value of this calcite is $-3.9 \pm 0.2$ relative to PDB. 


\begin{tabular}{|c|c|c|c|c|c|}
\hline No. & Rock & Mineral & $\begin{array}{c}\delta 0^{18} / 0^{16} \\
(\text { permil) }\end{array}$ & $\begin{array}{l}\text { Average } \\
\text { Deviation }\end{array}$ & $\begin{array}{l}\text { No. of } \\
\text { Runs }\end{array}$ \\
\hline \multirow[t]{2}{*}{ D6 } & pegmatite & quartz & 15.1 & - & 1 \\
\hline & & muscovite & 12.6 & - & 1 \\
\hline \multirow[t]{6}{*}{ D7 } & schist & quartz & 15.6 & 0.1 & 3 \\
\hline & & plagioclase & 13.3 & - & 1 \\
\hline & & muscovite & 12.6 & 0.3 & 3 \\
\hline & & garnet & 10.8 & 0.1 & 2 \\
\hline & & biotite & 10.3 & - & 1 \\
\hline & & magnetite & 6.4 & - & 1 \\
\hline \multirow[t]{5}{*}{ DI2 } & schist & quartz & 15.2 & 0.3 & 2 \\
\hline & & muscovite & 12.9 & - & 1 \\
\hline & & garmet & 10.9 & - & 1 \\
\hline & & biotite & 10.2 & 0.2 & 2 \\
\hline & & magnetite & 6.1 & 0.2 & 2 \\
\hline \multirow[t]{2}{*}{ DI2 } & pegmatite & quartz & 15.1 & 0.3 & 2 \\
\hline & & plagioclase & 13.4 & - & 1 \\
\hline \multirow[t]{2}{*}{$D 46$} & amphibolite & quartz & 9.5 & - & 1 \\
\hline & & hornblende & $5 \cdot 7$ & - & 1 \\
\hline \multirow[t]{4}{*}{$D 47$} & schist & quartz & 15.0 & 0.1 & 2 \\
\hline & & garnet & 10.0 & 0.0 & 2 \\
\hline & & biotite & 9.5 & 0.4 & 2 \\
\hline & & magnetite & 5.8 & - & 1 \\
\hline \multirow[t]{2}{*}{ D3 } & gneiss & quartz & 12.9 & - & 1 \\
\hline & & biotite & 7.0 & 0.2 & 2 \\
\hline D50 & schist & quartz & 13.1 & - & 1 \\
\hline
\end{tabular}




\begin{tabular}{|c|c|c|c|c|c|}
\hline No. & Rock & Mineral & $80^{18} / 0^{16}$ & $\begin{array}{l}\text { Average } \\
\text { Deviation }\end{array}$ & $\begin{array}{l}\text { No. of } \\
\text { Runs }\end{array}$ \\
\hline \multirow[t]{3}{*}{ D5la. } & schist & quartz & 13.0 & - & 1 \\
\hline & & plagioclase & 12.0 & 0.1 & 2 \\
\hline & & biotite & $7 \cdot 3$ & 0.1 & 3 \\
\hline \multirow[t]{3}{*}{ D51b } & pegmatitic & quartz & 13.2 & 0.2 & 2 \\
\hline & granite & K-feldspar & 12.2 & - & 1 \\
\hline & & muscovite & 10.0 & - & 1 \\
\hline \multirow[t]{2}{*}{ D52 } & metadiorite & quartz & 11.6 & - & 1 \\
\hline & & biotite & 5.5 & - & 1 \\
\hline \multirow[t]{3}{*}{ C518 } & schist & quartz & 15.1 & 0.2 & 4 \\
\hline & & biotite & 6.7 & 0.1 & 2 \\
\hline & & IImenite & 3.0 & 0.0 & 2 \\
\hline \multirow[t]{5}{*}{ IAT1 } & schist & quartz & 14.2 & 0.2 & 2 \\
\hline & & muscovite & 10.4 & 0.2 & 2 \\
\hline & & biotite & 7.1 & 0.2 & 2 \\
\hline & & chlorite & 5.5 & - & 1 \\
\hline & & ilmenite & 3.6 & 0.2 & 2 \\
\hline \multirow[t]{3}{*}{ IAI 68} & schist & quartz & 16.1 & 0.2 & 2 \\
\hline & & biotite & 8.5 & 0.1 & 2 \\
\hline & & 1lmenite & 6.7 & 0.3 & 2 \\
\hline \multirow[t]{4}{*}{ IA33 } & schist & quartz & 16.1 & 0.2 & 2 \\
\hline & & garnet & 10.5 & 0.3 & 2 \\
\hline & & chlorite & 8.4 & 0.2 & 2 \\
\hline & & magnetite & 5.9 & 0.1 & 2 \\
\hline LAIOp & schist & garnet & 10.8 & 0.1 & 2 \\
\hline
\end{tabular}




\begin{tabular}{|c|c|c|c|c|c|}
\hline No. & Rock & Mineral & $\begin{array}{r}80^{18} / 0^{16} \\
(\text { permil })\end{array}$ & $\begin{array}{c}\text { Average } \\
\text { Deviation }\end{array}$ & $\begin{array}{l}\text { No. of } \\
\text { Runs }\end{array}$ \\
\hline$(\mathrm{IA} I 68,33,10)$ & quartz & 16.0 & & & \\
\hline Hypothetical & albite & 13.9 & & & \\
\hline assemblage & muscovite & 12.0 & & & \\
\hline compiled from & garnet & 10.7 & & & \\
\hline analyses of & biotite & 8.8 & & & \\
\hline IAI68, IA33, & chlorite & 8.7 & & & \\
\hline and IAIOp\&q by & ilmenite & 6.7 & & & \\
\hline Taylor \&Garlick & magnetite & 5.8 & & & \\
\hline \multirow[t]{2}{*}{ V6 } & schist & quartz & 13.1 & - & 1 \\
\hline & & biotite & 5.7 & - & 1 \\
\hline \multirow[t]{4}{*}{ EVI8 } & schist & quartz & 11.6 & 0.1 & 2 \\
\hline & & muscovite & 8.3 & - & 1 \\
\hline & & magnetite & 1.9 & 0.2 & 3 \\
\hline & & hematite & 0.9 & 0.2 & 3 \\
\hline \multirow[t]{5}{*}{ EVI7s } & schist & quartz & 10.5 & 0.2 & 2 \\
\hline & & muscovite & 6.8 & - & 1 \\
\hline & & biotite & 4.7 & 0.2 & 4 \\
\hline & & chlorite & 3.4 & 0.3 & 3 \\
\hline & & magnetite & 0.1 & 0.2 & 4 \\
\hline \multirow[t]{3}{*}{ EVI7a } & amphibolite & quartz & 10.8 & 0.1 & 2 \\
\hline & & hornblende & 5.7 & 0.2 & 2 \\
\hline & & chlorite & 4.0 & - & 1 \\
\hline \multirow[t]{5}{*}{ EV2O } & schist & quartz & 10.2 & 0.2 & 2 \\
\hline & & muscovite & 7.0 & 0.1 & 2 \\
\hline & & garnet & 5.5 & - & 1 \\
\hline & & $\begin{array}{l}\text { biotite } \\
\text { chlorite }\end{array}$ & $\begin{array}{l}4.2 \\
3.2\end{array}$ & $\begin{array}{l}0.1 \\
0.4\end{array}$ & $\begin{array}{l}2 \\
2\end{array}$ \\
\hline & & ilmenite & 1.3 & - & 1 \\
\hline
\end{tabular}




\begin{tabular}{|c|c|c|c|c|c|}
\hline No. & Rock & Mineral & $\begin{array}{c}0^{18} / 0^{16} \\
(\text { permil) }\end{array}$ & $\begin{array}{l}\text { Average } \\
\text { Deviation }\end{array}$ & $\begin{array}{l}\text { No. of } \\
\text { Runs }\end{array}$ \\
\hline \multirow[t]{2}{*}{ VEI2b } & schist & quartz & 15.0 & 0.2 & 4 \\
\hline & & muscovite & 12.0 & 0.2 & 2 \\
\hline & & gamet & 10.7 & 0.2 & 3 \\
\hline & & biotite & 10.0 & 0.1 & 2 \\
\hline & & magnetite & 6.0 & 0.3 & 3 \\
\hline \multirow[t]{6}{*}{ P12a } & schist & quartz A & 16.5 & - & 1 \\
\hline & & garmet A & 11.4 & - & 1 \\
\hline & & quartz B & 16.5 & - & 1 \\
\hline & & garnet B & 11.2 & - & 1 \\
\hline & & quartz C & 16.4 & - & $I$ \\
\hline & & garmet C & 11.6 & - & 1 \\
\hline \multirow[t]{3}{*}{ RCC } & amphibolite & quartz & 11.9 & 0.1 & 2 \\
\hline & & hormblende & $7 \cdot 3$ & 0.1 & 2 \\
\hline & & magnetite & 1.5 & 0.1 & 2 \\
\hline \multirow[t]{2}{*}{$\mathrm{RZ}$} & schist & quartz & 13.6 & 0.0 & 2 \\
\hline & & garnet & 8.6 & 0.4 & 3 \\
\hline \multirow[t]{5}{*}{$\mathrm{F} 22 \mathrm{~b}$} & schist & quartz & 14.5 & 0.2 & 2 \\
\hline & & muscovite & 11.8 & 0.1 & 2 \\
\hline & & gamet & 10.1 & 0.3 & 3 \\
\hline & & biotite & 9.2 & 0.2 & 2 \\
\hline & & chlorite & $7 \cdot 5$ & 0.3 & 2 \\
\hline \multirow[t]{5}{*}{ S35j } & schist & quartz & 14.7 & 0.1 & 3 \\
\hline & & muscovite & 11.7 & - & 1 \\
\hline & & garmet & 10.1 & 0.4 & 2 \\
\hline & & biotite & 8.9 & 0.1 & 2 \\
\hline & & chlorite & $7 \cdot 3$ & - & 1 \\
\hline
\end{tabular}




\begin{tabular}{|c|c|c|c|c|c|}
\hline No. & Rock & Mineral & $\begin{array}{c}80^{18} / 0^{16} \\
(\text { permil) }\end{array}$ & $\begin{array}{l}\text { Average } \\
\text { Deviation }\end{array}$ & $\begin{array}{l}\text { No. of } \\
\text { Runs }\end{array}$ \\
\hline \multirow[t]{2}{*}{ GBF3 } & quartzite & quartz & 14.3 & 0.2 & 2 \\
\hline & & magnetite & 4.9 & - & 1 \\
\hline \multirow[t]{2}{*}{ GBFI } & pegmatite & quartz & 14.4 & - & 1 \\
\hline & & muscovite & 10.6 & - & 1 \\
\hline $\mathrm{GBF} 2$ & vein & quartz & 14.1 & - & 1 \\
\hline \multirow[t]{3}{*}{$4167 g$} & gneiss & quartz & 11.6 & 0.2 & 2 \\
\hline & & biotite & 5.3 & 0.2 & 2 \\
\hline & & magnetite & 0.7 & 0.2 & 2 \\
\hline $4182 c$ & schist & quartz & 14.9 & - & 1 \\
\hline 4042 & schist & quartz & 14.2 & - & 1 \\
\hline \multirow[t]{7}{*}{$4186 c$} & xenolith & quartz 1 & 13.8 & - & 1 \\
\hline & of schist & quartz 2 & 11.8 & - & 1 \\
\hline & & quartz 3 & 10.9 & 0.2 & 2 \\
\hline & & garnet & 10.2 & 0.1 & 2 \\
\hline & & muscovite & 8.0 & 0.2 & 2 \\
\hline & & biotite & 4.5 & - & 1 \\
\hline & & ilmenite & 2.6 & - & 1 \\
\hline $4186 \mathrm{~g}$ & trondjemite & quartz & 10.8 & - & 1 \\
\hline CSG3 & granite & quartz & 9.7 & - & 1 \\
\hline \multirow[t]{2}{*}{ CSGI } & gneiss & quartz & 8.8 & - & 1 \\
\hline & & biotite & 2.5 & 0.2 & 2 \\
\hline \multirow[t]{2}{*}{ A.66a } & quartzite & quartz & 14.8 & 0.1 & 2 \\
\hline & & muscovite & 11.4 & 0.1 & 2 \\
\hline
\end{tabular}




\begin{tabular}{|c|c|c|c|c|c|}
\hline No. & Rock & Mineral & $\begin{array}{c}80^{18} / 0^{16} \\
\text { (permi1) }\end{array}$ & $\begin{array}{c}\text { Average } \\
\text { Deviation }\end{array}$ & $\begin{array}{l}\text { No. of } \\
\text { runs }\end{array}$ \\
\hline \multirow[t]{3}{*}{ A66a } & quartzite & garnet & 11.0 & 0.2 & 2 \\
\hline & & biotite & 8.5 & 0.1 & 2 \\
\hline & & magnetite & 5.0 & 0.1 & 3 \\
\hline \multirow[t]{5}{*}{ A57a } & quartzite & quartz & $15 \cdot 9$ & 0.1 & 2 \\
\hline & & muscovite & 12.9 & - & 1 \\
\hline & & garnet & 11.5 & 0.2 & 2 \\
\hline & & biotite & 10.0 & 0.3 & 2 \\
\hline & & ilmenite & 8.2 & 0.2 & 2 \\
\hline \multirow[t]{3}{*}{ A. $5 \mathrm{~h} 4$} & amphibolite & quartz & 10.8 & - & 1 \\
\hline & & hornblende & 6.4 & - & 1 \\
\hline & & biotite & 5.7 & 0.2 & 2 \\
\hline \multirow[t]{3}{*}{$\mathrm{A} 56 j$} & schist & quartz & 11.6 & - & 1 \\
\hline & & garmet & 7.7 & 0.2 & 3 \\
\hline & & biotite & 6.9 & 0.3 & 3 \\
\hline \multirow[t]{4}{*}{$\mathrm{A} 64 \mathrm{~g}$} & gneiss & quartz & 14.0 & 0.1 & 3 \\
\hline & & garnet & 10.6 & 0.2 & 2 \\
\hline & & biotite & 9.7 & 0.1 & 2 \\
\hline & & ilmenite & 7.2 & 0.1 & 3 \\
\hline \multirow[t]{5}{*}{ АН2096 } & schist & quartz & 14.8 & 0.2 & 2 \\
\hline & & muscovite & 11.7 & - & 1 \\
\hline & & garnet & 10.3 & - & 1 \\
\hline & & biotite & 9.3 & - & 1 \\
\hline & & ilmenite & 6.0 & 0.2 & 2 \\
\hline \multirow[t]{3}{*}{1319} & schist & quartz $A$ & 8.7 & - & 1 \\
\hline & & kyanite A & 6.3 & 0.1 & 2 \\
\hline & & garnet A & 5.1 & - & 1 \\
\hline
\end{tabular}




\begin{tabular}{|c|c|c|c|c|c|}
\hline No. & Rock & Mineral & $\begin{array}{c}80^{18} / 0^{16} \\
(\text { permil })\end{array}$ & $\begin{array}{c}\text { Average } \\
\text { Deviation }\end{array}$ & $\begin{array}{l}\text { No. of } \\
\text { Runs }\end{array}$ \\
\hline \multirow[t]{5}{*}{1319} & schist & quartz B & 8.4 & - & 1 \\
\hline & & gamet $B$ & 5.1 & - & 1 \\
\hline & & quartz C & 8.9 & - & 1 \\
\hline & & kyanite C & 6.1 & - & 1 \\
\hline & & chlorite $\mathrm{C}$ & 3.5 & - & 1 \\
\hline \multirow[t]{3}{*}{1321} & amphibolite & quartz & 9.2 & 0.2 & 2 \\
\hline & & hornblende & 5.1 & 0.1 & 3 \\
\hline & & garnet & 3.9 & 0.1 & 2 \\
\hline \multirow[t]{3}{*}{$912 a$} & schist & quartz & 9.0 & 0.2 & 2 \\
\hline & & muscovite & 6.4 & 0.2 & 2 \\
\hline & & Mg-biotite & $4 \cdot 3$ & 0.1 & 2 \\
\hline \multirow[t]{3}{*}{$\mathrm{AH} 243$} & schist & quartz & 14.2 & 0.2 & 2 \\
\hline & & biotite & 8.5 & 0.1 & 2 \\
\hline & & ilmenite & 6.8 & 0.2 & 2 \\
\hline \multirow[t]{4}{*}{ SY22 } & schist & quartz & 12.4 & 0.1 & 2 \\
\hline & & kyanite & 8.9 & - & 1 \\
\hline & & garnet & 8.5 & 0.3 & 2 \\
\hline & & biotite & 8.3 & 0.1 & 3 \\
\hline \multirow[t]{4}{*}{$Q M$} & quartz & quartz & 9.2 & 0.1 & 2 \\
\hline & monzonite & K-feldspar & 7.4 & 0.1 & 2 \\
\hline & & biotite & 2.9 & 0.2 & 3 \\
\hline & & magnetite & 1.1 & 0.1 & 2 \\
\hline \multirow[t]{3}{*}{5536} & sericitic & quartz & 9.1 & - & 1 \\
\hline & alteration & K-feldspar & -0.6 & 0.2 & 2 \\
\hline & & sericite & & & \\
\hline 5536 & vein & quartz & -0.1 & - & 1 \\
\hline
\end{tabular}

